THE VIEW FROM THE OTHER SIDE OF THE AISLE:

Congressional Party Switchers and their Environments

\author{
A Dissertation presented to \\ the Faculty of the Graduate School \\ at the University of Missouri-Columbia \\ In Partial Fulfillment \\ of the Requirements for the Degree \\ Doctor of Philosophy \\ by \\ BENJAMIN L. HALL \\ Dr. L. Marvin Overby, Dissertation Supervisor \\ DECEMBER 2013
}


The undersigned, appointed by the dean of the Graduate School, have examined the dissertation entitled

\section{THE VIEW FROM THE OTHER SIDE OF THE AISLE: Congressional Party Switchers and their Environments}

presented by Benjamin L. Hall, a candidate for the degree of doctor of philosophy, and hereby certify that, in their opinion, it is worthy of acceptance.

Professor L. Marvin Overby

Professor Peverill Squire

Professor John Petrocik

Professor Mitchell McKinney 
For my parents and for Becky Winkler. 


\section{ACKNOWLEDGEMENTS}

There are so many people whose contributions made this project possible. I would like to thank Professor Marvin Overby for his indispensable guidance in this process. Without his advice and input this accomplishment would not have been possible. I also want to thank Professor Peverill Squire for his contributions. I drew on his considerable expertise in determining the appropriate direction of this research. I would also like to thank Professors John Petrocik, Mitchell McKinney, and Bill Benoit for their input and flexibility through this process. In crafting this dissertation I drew on the experiences of several former members of Congress. As such, I want to thank Representatives Michael Forbes, Virgil Goode, Peter Peyser, and Eugene Atkinson as well as Senator Harry Byrd, $\mathrm{Jr}$.

Thanks to all my fellow graduate students, especially Paul Bellinger, Nisha Mukherjee Bellinger, Jordan Crawford, and Susan Miller, for their support and encouragement. Special thanks to Paula Dohnal for her editorial efforts and expertise. Thanks to the always helpful political science departmental staff, including Audra Jenkins and Sarah Turner. I want to thank all the scholars whose work laid the foundation for my own. That list includes too many people to name, but among them are Nolan McCarty, Keith Poole, Howard Rosenthal, Timothy Nokken, Antoine Yoshinaka, James Fowler, Keith Krehbiel, Gary Cox, Matthew McCubbins, John Aldrich, and David Rohde. I want to thank those who aided my data collection efforts including staff members in the offices of secretaries of state in Alabama, Colorado, New York, Virginia, Georgia, and Louisiana. I also want to thank the support staff of the Federal Election Commission, who aided me tremendously. Thanks to the leadership and staff of the University of Missouri, who provided the facilities and support to make this project possible. 


\section{TABLE OF CONTENTS}

ACKNOWLEDGEMENTS ................................................................................ ii

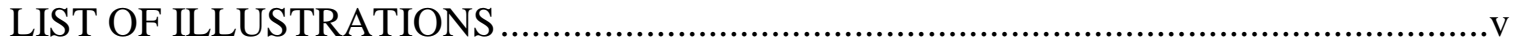

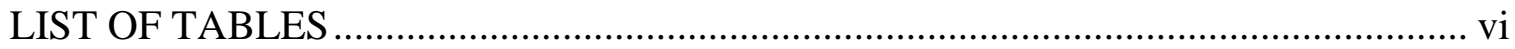

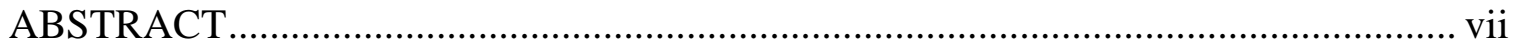

Chapter

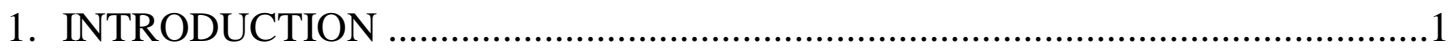

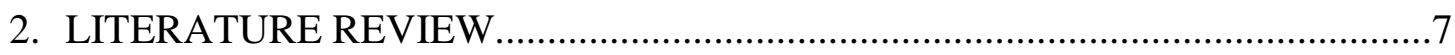

Party Switchers: Who Takes the Leap?

Cases

3. FUNDRAISING, GEOGRAPHIC CONSTITUENCIES, AND PARTY ..............22

Cases

Ben Nighthorse Campbell

Rodney Alexander

Nathan Deal

Michael Forbes

Richard Shelby

Summary

4. THE SOCIAL ENVIRONMENTS OF PARTY SWITCHERS

Previous Study of Cosponsorship

Theory, Data, and Measurement

Results

Switchers to the Republican Party

Switchers to the Democratic Party

Peter Peyser 
Phil Gramm

Switchers to Independent Status

Party Switching and House Committee Assignments

Violations of Committee Seniority Norms for Party Switchers

Summary

5. PARTY SWITCHERS IN THEIR OWN WORDS

Michael Forbes’s Switch: A Tough Fight in New York

Arlen Specter's Switch: Fighting Off the “Cannibals”

Harry F. Byrd Jr.’s Partisan Independence: A Success Story from Virginia

Virgil Goode Jr.: Another Winning Approach in Virginia

Peter Peyser: More Tension in New York

Eugene Atkinson, Ronald Reagan, and the Struggle to Save Steel in Pennsylvania

Psychological Impact of Group Membership

The Elusive Effects of Political Culture

6. CONCLUSION

Inconsistent Success of Party Switchers

Future Research

Closing Thoughts

BIBLIOGRAPHY

VITA 148 


\section{LIST OF ILLUSTRATIONS}

Figure $\quad$ Page

1. Corporate Receipts for Party Switchers .......................................................24

2. Labor Receipts for Party Switchers ...........................................................26

3. Changes in Vote Share Ben Campbell ...............................................................32

Experienced After Becoming a Republican

4. Changes in Vote Share Rodney Alexander ......................................................37

Experienced After Becoming a Republican

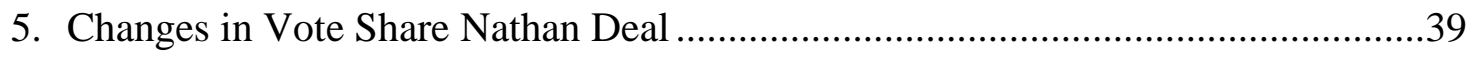

Experienced After Becoming a Republican

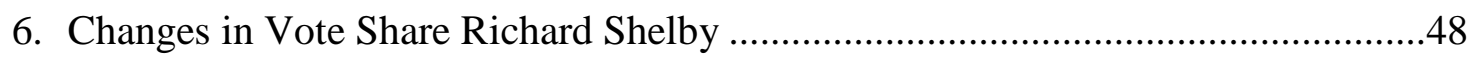

Experienced After Becoming a Republican

7. Composite Cosponsorship Scores for ...........................................................66

Party Switchers (percent Republican), 1980-2013

8. Support Given by Party Switchers ..............................................................68

to Republican-Sponsored Bills, 1980-2010

9. Support Received by Party Switchers from Republicans, 1980-2013 ...................70 


\section{LIST OF TABLES}

Table

Page

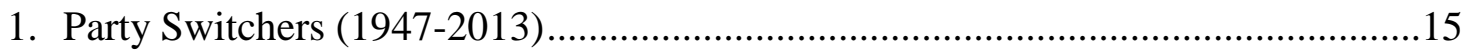

2. Senate Switchers' Age at the Time of Defection .............................................17

3. House Switchers' Age at the Time of Defection................................................18

4. Senate Switchers' Tenure at the Time of Defection.............................................19

5. House Switchers’ Tenure at the Time of Defection ...........................................19

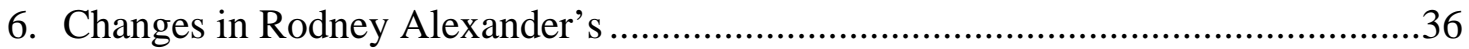

Labor Union Performance Ratings

7. Correlations Between Changes in Switchers' ...................................................49

Vote Shares and Average Partisan Vote

8. Average regional change in electoral support after changing parties ....................50

9. Shifts in composite cosponsorship scores for party switcher...............................64

10. Comparison of Changes in Support Given and Support Received .........................69

11. House Committee Assignment Shifts for Party Switchers, 1975-1991 ...................79

12. House Committee Assignment Shifts for Party Switchers, 1995-2011 ..................80 


\begin{abstract}
In recent years, numerous congressional scholars have found that political parties matter to members of Congress. Among the powers parties hold are the abilities to stop the passage of bills party leaders oppose, to reward or punish legislators for their behavior, and to protect their members from votes that divide their constituents. In this study I go beyond the role of parties’ direct control of the legislative process to examine how parties matter as part of a legislator's overall environment. Using members of Congress who have switched parties as a natural experiment, I find that parties influence numerous elements of members' environments. My results show that a member of Congress who switches parties can expect changes in the geographic makeup of his electoral support, in the types of campaign donors he attracts, and in the social networks in which he operates. I supplement these findings using information gained from interviews with some of the members in question.
\end{abstract}




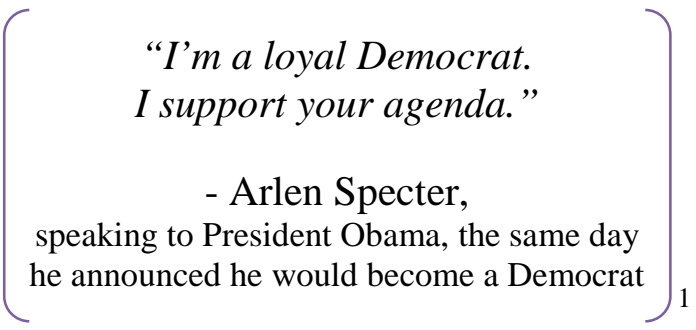

\section{Introduction}

Political partisanship in the United States is a multifaceted phenomenon, affecting aspects of political life from legislative control to electoral organization and public perception of political figures. Across the institutional and organizational dimensions of American partisanship, parties have purportedly declined in power due to developments that include a number of progressive reforms. Consequently, some scholars have questioned whether parties matter to American legislative behavior as anything more than a mechanism for collecting useful information (e.g., Krehbiel 1991; 1993). A wealth of research has refuted those claims, suggesting that American political parties have a significant impact on the legislative process in different ways and under different conditions (e.g., Aldrich 1995; Aldrich and Rohde 2000; Cox and McCubbins 1993; 2005; Jenkins 1999; Rohde 1991). In one recent paper, McCarty, Poole, and Rosenthal (2001) (hereafter MPR) use congressional party switchers as a natural experiment to demonstrate the effect of partisanship on role-call voting behavior. The authors find that, rather than "dying in their ideological boots" like other members of Congress (see e.g., Poole 2007), switchers alter their voting behavior in substantial and expected ways. In this study I examine the broader effects of partisanship, analyzing characteristics of legislators' environments to elucidate the environmental conditions that party engenders.

\footnotetext{
${ }^{1}$ Parker, Jennifer. 2009. “Specter Switches Sides; Tells Obama: 'I’m a Loyal Democrat.”” Politics. 28 April. http://abcnews.go.com/blogs/politics/2009/04/specter-switche/ (March 13, 2013).
} 
Across a number of different aspects of the legislative environment, I find that party affiliation produces considerable and predictable change.

The partisan character of voting behavior in the party-switching population has been well-documented. Democratic members who become Republicans vote more conservatively and vice versa. MPR also suggest that party discipline is "part of a legislator’s overall environment that forms her induced preferences” (McCarty, Poole and Rosenthal 2001, 686). The purpose of this study is to use similar natural experiments to elucidate more precisely how parties influence legislators' overall environments. In this analysis, I clarify the changes that party defections produce for members of Congress (MCs) in their fundraising portfolios, electoral environments, and social networks.

I first examine the fundraising portfolios of party switchers in an effort to detect whether there is a partisan character to members' financial support structures. Second, I analyze switchers' geographic constituencies, developing a more complete picture of how a change in party affiliation affects the geographic distribution of members' electoral support. Third, I examine switchers' social networks within Congress to determine whether switching party affiliation produces a corresponding change in working relationships with other legislators. Fourth, I analyze the thoughts of several party switchers more closely, using interviews to ask members directly about their switching experiences.

My approach combines diverse research methods to paint as clear a picture as possible of partisan legislative environments. On each dimension of environmental partisanship I find hypothesized effects, showing that, above and beyond a member's personal ideological convictions, party affiliation influences all kinds of environmental 
conditions. When the same member operates under different party labels, he can expect predictable changes in electoral conditions, interest group support, intra-legislative working relationships, and a number of other factors such as media endorsements and staff makeup.

Beyond these shifting conditions, congressional party switchers can also expect dramatic and immediate changes in their relationships with party leaders. Generally, the resulting schism provides both benefits and hinders the MC. Modern accounts of party switching suggest that, whether or not the switcher's former party affiliates are the sources of electoral failure, party switchers are often unsuccessful in subsequent elections. However, switchers' new parties often exert considerable effort to keep the member in office, securing the seat for their caucus.

This behavior by party leaders is not entirely surprising. It is true that an ideology-driven theory of legislative influence might suggest that party leaders would be minimally perturbed by changes in member affiliations. Under that theoretical framework, leaders should believe that the member's unchanged ideological positions will make him just as agreeable a bargaining partner after the switch. However, legislative interaction involves more than simple bargaining behavior, and the maintenance of party control (and leader status) is of course based on the size of the caucus. Nevertheless, an advocate of the organizational theory of legislative organization might be surprised at the vigor and acrimony with which partisan opponents seek to unseat and in some cases even humiliate party switchers.

The vehemence with which partisan operatives of various stripes contest members seen as traitors to the party suggests that, for many key figures in Washington, party is 
less an organizational category and more a cherished element of personal identity. The quantitative evidence presented here suggests that voters, influence groups, and a significant collection of inside-the-beltway professionals share that attitude toward party identity and affiliation. The qualitative data I present suggests that many figures within Congress see themselves as participants in a zero-sum legislative game, with the teams divided along party lines. 
“...we cannot, in good conscience, continue working for him."

- Sharon Wheeler

(Parker Griffith’s Chief of Staff)

\section{Literature Review}

The impact of parties on legislative behavior has been a hotly debated topic among political scientists for more than a decade. Much of the scholarship in this area has focused on questions about the degree to which parties can be said to affect legislative organization and process (e.g., Cox and McCubbins 1993; 2005; Krehbiel 1993) and the conditions under which strong partisan influence should be expected (e.g., Aldrich and Rohde 2000; Rohde 1991). Most of the findings in this area suggest that, in some significant way, parties affect their members' legislative behavior (e.g., Aldrich and Rohde 2000; Cox and McCubbins 1993; 2005; Jenkins 1999; Rohde 1991; Wright and Schaffner 2002). Less attention has been paid to questions of what partisanship means for legislators' environments. MPR go so far as to suggest that members' overall environments dictate their preferences, but we know relatively little about the role that partisanship has in shaping these environments.

A major reason for this lack of information lies in the static nature of party membership for the vast majority of MCs. Legislators simply do not change parties very often. The reasons for this are numerous. Not only does switching parties pose a risk to one's political career, but tied up with one's party affiliation are personal issues of ideology, identity, culture, loyalty, and even character. Most members would choose not to switch parties, not out of fear of political fallout, but simply because they have chosen

\footnotetext{
2 Simon, Jeff. 2010. “Parker Griffith’s Staff Resigns.”’ Political Ticker. 4 January. http://politicalticker.blogs.cnn.com/2010/01/04/parker-griffiths-staff-resigns/ (March 17, 2013).
} 
the party in which they feel more comfortable. The feeling that one's party is the best choice is a quality that each member shares with most other members of her party caucus. Given the tremendous influence in both candidate evaluation and vote choice that party identification holds for voters (e.g., Campbell, Converse, Miller, and Stokes 1960; LewisBeck, Jacoby, Norpoth, and Weisberg 2008), it should be no surprise that strong partisan feelings are present at the elite level as well.

The importance of partisanship in citizen voting behavior has been thoroughly documented. As Campbell et al. (1960) originally suggested and subsequent studies have confirmed, party identification is the key predictor of individual voting behavior among Americans. Accordingly, one would expect a legislator's electoral fortunes and the types of supporters she attracts to depend in large part on the party label under which she chooses to run. Changes in party affiliation, therefore, should generate changes in support and in "overall environment," as suggested by MPR. The disparities between the major U.S. parties in their composition, the donors they attract, and the regions in which they win are relatively well known. However, party switchers present a test of the strength of these differences. This analysis poses the question of whether these differences persist even when the member himself remains the same.

Scholars continue to debate how best to conceptualize the role constituencies play in motivating legislative behavior. Miller and Stokes (1963) suggest that Congress strictly follows neither a delegate nor a trustee model of lawmaking, but incorporates elements of both. Legislators listen to constituents on some kinds of issues but not others. Some researchers employ Fenno's (1978) typology, which contends that legislators view their supporters in terms of geographic, reelection, primary, and personal 
constituencies, each group being a subset of the last. Others suggest that rather than focusing on whether legislators vote in a manner congruent with the preferences of their constituents, congressional scholars should instead focus on responsiveness, a phenomenon which can manifest in the form of a change of policy, an allocation of funds, an act of constituency service, or a symbolic action (Eulau and Karps 1977). Further evidence suggests that the constituency influence is more complex than simple congruence between legislator and district preferences. One prominent study shows that the timing of major legislative decisions can also be influenced by constituent characteristics (Box-Steffensmeier, Arnold, and Zorn 1997).

These different methods of conceptualizing the issue of constituency responsiveness each have merits, but these scholars tend to agree with Mayhew's (1974) assertion that legislators focus on reelection and, in one way or another, are responsive to constituents. This responsiveness may take the form of a symbolic or case-specific response to a constituent's concerns, but it may also take the form of a policy change or a key vote on important legislation. Regardless of the theoretical model one uses to understand the interaction between legislator and district, significant evidence suggests that that MCs spend considerable time and effort responding to issues raised by constituents (e.g., Fenno 1977; 1978). Legislators’ own evaluations of their time commitments emphasize the claim that they spend more time meeting with constituents both at home and in Washington than they spend doing almost anything else (Davidson, Oleszek, and Lee 2010, 137).

There can be little doubt that this time commitment is an act of self-preservation, but so much interaction with voters from one's district is bound to have some influence 
on a member's legislative behavior. Evidence already suggests that some voters are more likely to contact their members of Congress if they belong to the same racial category (Gay 2002). This tendency to be more open to contact with people with perceived commonalities is unlikely to be limited to racial groups. One should expect voters who identify more with one party (and consequently judge candidates and officials from that party differently than others) to be more likely to direct their appeals at the legislators who share their partisan affiliation. Most congressional delegations contain members of both parties, so, given the choice of a Democrat or a Republican legislator, why would a staunch Democrat contact his Republican representative all else being equal? Although this study does not attempt to measure communication between constituents and legislators, constituent feedback may be yet another dimension in which party influences a legislator’s environment.

Parties are made still more important by the ways in which they are interwoven into the functions of Congress. Not only do the parties and their leadership play a major role in the organization of committees, they also involve themselves in candidate fundraising (both providing and asking for funds), play lead roles in legislative negotiations, shape the nature of procedural rules, and so forth. One significant power the parties, especially the House majority, hold is negative power (Cox and McCubbins 1993; 2005). If members of the House majority aspire to sponsor successful legislation, they must consider the possible effects that their interactions with leadership may have on the prospects for their favorite bills. Leaders may not be able to push through unpopular legislation, but they can often kill a bill without much opposition. 
Evidence suggests that the ability of leaders to exercise positive power is more conditional, being more readily visible when one side holds a sizeable majority. The majority leadership in the Senate, for example, will have a much easier time passing the legislation it wants with a 60 -vote majority than it will with a simple majority, ceteris paribus. The result is that the power of parties and their leaders is far from absolute, but members must consider how this power structure could adversely affect them if they fail to meet leaders' expectations.

A number of studies have already employed natural experiments as a means to examine the nature of partisanship, although none have examined the questions I address here. One such study finds evidence of significant party behavior using natural experiments comparing Nebraska’s nonpartisan unicameral legislature to the Kansas Senate (Wright and Schaffner 2002). Another does so by comparing the partisan U.S. House and nonpartisan Confederate House of Representatives (Jenkins 1999). A growing number of analyses indicate that party switchers represent a useful natural experiment for the effect of partisanship (e.g., Desposato 2006; Heller and Mershon 2005; McCarty, Poole, and Rosenthal 2001; Nokken 2000; 2005; Nokken and Poole 2004). Those studies of U.S. legislators generally focus on changes in voting behavior following the switch but neglect to investigate corresponding changes in campaign funding, electoral environment, and social networks.

These facets of legislators' environments are important for several reasons. The potential influence of one's electoral environment is obvious. New electoral supporters and the loss of previously supportive voters would mean a shifting reelection constituency. Inasmuch as MCs are accountable to the voters who actually support them 
in their districts—-their reelection constituency—shifts in those constituent groups have the considerable potential to affect the electoral gains and losses members can expect from key public decisions. Votes in support of the major health care reform bills signed into law by President Obama, for example, could receive a much different response among Republican constituents than among Democratic ones.

Although scholars have had difficulty finding strong and consistent connections between congressional voting behavior and campaign contributions (see Smith 1995), there is reason to suspect that legislators' relationships with lobbyists and interest groups offer an opportunity for those groups to influence legislative behavior of one kind or another. It may be worth noting that one area in which contributions have been directly linked to legislative action is that of labor PAC contributions (Wilhite and Theilmann 1987), one of the key variables examined here. The other key variable used here is that of corporate PAC contributions, which recent scholarship suggests have been used as a means for business interests to take punitive action against MCs for "incorrect" votes on issues affecting businesses (Jackson and Engel 2003).

Another means of trading resources for influence could come in the form of lobbying firms hiring former members of Congress to represent them in the legislature. This activity could serve as delayed compensation for supportive MCs and poses the considerable possibility for influence as 325 former MCs (10 of them party switchers) currently hold some role in the lobbying industry (OpenSecrets.org 2010). The portion of this project that concerns campaign fundraising does not seek to establish empirically the connection between financial contributions and legislative behavior. Its primary goal is instead to establish that switchers' fundraising environments change in predictable ways. 
Whether or not shifts in financial support directly prompt changes in legislative behavior, they represent changes in the types of pressure groups that seek to influence MCs through all kinds of lobbying methods. If the result of party switching is a shift in the kinds of groups lobbying a member, another result may be a change in the information the legislator receives. To the extent that a legislator’s support among interest groups changes, it can be conceptualized as a shift in the portion of an issue network to which that member is exposed.

Another potential influence on a member's behavior is the group of colleagues with whom he chooses to associate. One recent study suggests that House members interact with only a small percentage of their fellow legislators (Fowler 2006). This revelation should not be surprising if one considers the relatively small groups (committees) in which legislators do much of their comingling with fellow representatives. According to the same study, senators are connected with a larger percentage of their chamber, but still a reasonably compact and collegial social group. The result is that a map of congressional social interactions is a series of tight clusters. The high level of compactness in these networks has been linked to legislative productivity (Tam Cho and Fowler 2010).

The authors of The American Voter mentioned that "personal forces" like a person changing neighborhoods might prompt that person to change party identification, because the change might expose the individual to new ideas and new social situations (Campbell et al. 1960, 150). The idea was that such experiences could cause a change in political orientation as well. Subsequent research has found empirical evidence of this phenomenon (e.g., Brown 1988; MacDonald and Franko 2008), showing that, among 
party identifiers in the general population, voters' political orientations are shaped by their environments. One cause attributed to these types of effects is the nature of information flow in social networks. Recent scholarship has found that when people discuss issues in a group, a participant with a minority viewpoint is less likely to change positions than one whose position is echoed by the majority of the group (Huckfeldt, Johnson, and Sprague 2002; 2004).

Research has also found that partisanship plays a key role in the behavior of groups facing collective action problems. One experimental study, for example, showed that partisans were more likely to contribute to collective goals and punish refusal to contribute to those goals (Smirnov, Dawes, Fowler, Johnson, and McElrath 2010). This finding should not be particularly surprising, as there is a wealth of evidence in the psychology literature showing that group membership influences social behavior (e.g., Brewer 1979; Lemyre and Smith 1985; Tajfel 1970). Indeed, one consistent finding in the American political behavior literature - that party identification influences candidate evaluation (e.g., Campbell et al. 1960; Lewis-Beck et al. 2008)—seems to indicate that, at the popular level, group attachments can be more influential than ideological ones. It would be unreasonable to expect the psychological constructs that affect interpersonal relationships and political perceptions outside Washington to disappear inside the beltway.

In much the same way as issue networks external to the legislature might be expected to influence legislative behavior, social networks, especially tightly-knit groups of the type suggested above and described in the interviews I conducted, offer MCs cues about how to behave. Fellow legislators have the ability to offer credible information and 
advice to their peers and have far more access than any lobbyist if only because of the privileges afforded them and the volume of time they spend on the Hill.

A variety of facets of a candidate's electoral environment may be reflected in neither geographic constituency nor fundraising patterns. I focus on a number of these, including newspaper endorsements, staff reactions, and noteworthy events prompted by switching. The methods of this section are largely qualitative, relying on newspapers and other press coverage as well as members' personal papers. Although the power of newspaper endorsements is a matter open to debate, they are certainly signals relevant to perceptions of candidate competence and desirability. Kahn and Kenney (2002) found that editorial endorsements also affect the slant of news content. This suggests that changes in endorsements may impact substantive coverage. Preliminary inquiry has found that Representative Nathan Deal lost his Atlanta Journal-Constitution endorsement in 1996, having become a Republican the previous year. In 1998, the paper did not endorse his opponent, but it did refuse to endorse any candidate in Deal's race. He also lost his endorsement from the Chattanooga Times, the primary newspaper endorsing the race in the metro area directly north of his district. By contrast, Ben Campbell received the Denver Post's endorsement as a Democrat in 1992 and retained it as a Republican in 1998. In 1992, however, he was endorsed in neither the primary nor the general election by the more conservative Rocky Mountain News, but he gained the paper's endorsement as a Republican in his reelection bid.

Another element of a candidate's electoral environment is her staff. I offer the hypothesis that, because many staff members are adamant partisans, changes in party affiliation will tend to result in sudden and substantial staff turnover. Preliminary 
qualitative analysis suggests that this is often the case. Campbell had a large portion of his Colorado staff quit after hearing about his switch. Representative Michael Forbes suffered an even larger hit. When the New York Times called his office for comment on his decision to become a Democrat, the paper could reach no one. Virtually all of the district staff had quit. In their letters of resignation, aides described the change as a “cowardly move” and a "radical departure from all [Forbes] supposedly held dear” (Schmitt 1999). One should not ignore the notion that the manner in which a switcher announces her decision is a potential mitigating factor in the reception it garners, but the news itself seems likely to have had some impact in these cases.

A variety of other events have occurred surrounding party switchers that suggest the substantial role of partisanship among elites. Party switchers regularly come under fire from the electoral organizations of their former parties and receive perks from their new ones.

\section{Party Switchers: Who Takes the Leap?}

In order for a natural experiment to be valid, the sample being studied should be as similar as possible to the larger population. Indeed, descriptive statistics suggest that party switchers as a group resemble the rest of the Congress in most respects. The one significant area of difference between switchers and the rest of the legislature is regional distribution. An average party switcher is more likely to be from the South than others MCs are. This can be explained by a number of factors, notably the relative similarity between the parties in the region and the larger trend of conservative southern Democrats joining the Republican Party. However, the sample is not exclusively southern and 
includes members from the Northeast, Midwest, and West Coast. Table 1 presents a full list of the party switchers analyzed in this study.

As of 2011, about 8 percent of MCs are African American and about 5 percent are Hispanic, but there have been no African-American party switchers and only one Latino: former House Representative Matthew Martínez of California (Clerk of the House 2011a). There are also no female party switchers, but more than 16 percent of MCs are women (Clerk of the House 2011b). One other party switcher identifies as a member of an ethnic minority: Native American former Senator Ben Nighthorse Campbell (CO). As of 2011, only one member of the House or Senate is a Native American: Tom Cole (ROK). The ethnic and gender characteristics of the sample distinguish it somewhat from the rest of the Congress, but to observe a perfectly representative sample would be unlikely. There is little theoretical reason to believe that the gender and ethnic orientations of party switchers have much effect on the consequences of their defections.

Table 1. Party Switchers (1947-2013)

\begin{tabular}{|c|c|c|c|c|c|c|}
\hline Chamber & State & Name & $\begin{array}{c}\text { Switch } \\
\text { Type }\end{array}$ & $\begin{array}{l}\text { Switched } \\
\text { (year) } \dagger\end{array}$ & $\begin{array}{c}\text { Left Office } \\
\text { (year) }\end{array}$ & $\begin{array}{c}\text { Reason for } \\
\text { Leaving Office }\end{array}$ \\
\hline House & LA & Alexander, Rodney & $\mathrm{D}$ to $\mathrm{R}$ & 2004 & NA & NA \\
\hline House & AR & Alford, Thomas D. & ID to $\mathrm{D}$ & 1960 & 1963 & Ran for Governor \\
\hline House & PA & Atkinson, Eugene V. & $\mathrm{D}$ to $\mathrm{R}$ & 1981 & 1983 & $\begin{array}{l}\text { Lost General } \\
\text { Election }\end{array}$ \\
\hline Senate & VA & Byrd, Harry F. Jr. & D to I & 1970 & 1983 & Retired \\
\hline Senate & $\mathrm{CO}$ & $\begin{array}{c}\text { Campbell, Ben } \\
\text { Nighthorse }\end{array}$ & $\mathrm{D}$ to $\mathrm{R}$ & 1995 & 2005 & Retired \\
\hline House & GA & Deal, J. Nathan & $\mathrm{D}$ to $\mathrm{R}$ & 1995 & 2010 & Ran for Governor \\
\hline House & NJ & Dellay, Vincent J. & $\mathrm{R}$ to $\mathrm{D}$ & 1957 & 1959 & $\begin{array}{c}\text { Lost General } \\
\text { Election }\end{array}$ \\
\hline House & PA & Foglietta, Thomas M. & I to $\mathrm{D}$ & 1982 & 1997 & Retired \\
\hline House & NY & Forbes, Michael P. & $\mathrm{R}$ to $\mathrm{D}$ & 1999 & 2001 & $\begin{array}{l}\text { Lost Primary } \\
\text { Election }\end{array}$ \\
\hline House & VA & Goode, Virgil H. Jr. & $\mathrm{D}$ to $\mathrm{I}$ to $\mathrm{R}$ & 2000 & 2009 & $\begin{array}{l}\text { Lost General } \\
\text { Election }\end{array}$ \\
\hline House & TX & Gramm, W. Philip & $\mathrm{D}$ to $\mathrm{R}$ & 1983 & 1985 & Ran for Senate \\
\hline House & FL & Grant, J. William & $\mathrm{D}$ to $\mathrm{R}$ & 1989 & 1991 & $\begin{array}{l}\text { Lost General } \\
\text { Election }\end{array}$ \\
\hline House & AL & Griffith, Parker & $\mathrm{D}$ to $\mathrm{R}$ & 2009 & 2011 & Lost Primary \\
\hline
\end{tabular}




\begin{tabular}{|c|c|c|c|c|c|c|}
\hline & & & & & & Election \\
\hline House & TX & Hall, Ralph M. & $\mathrm{D}$ to $\mathrm{R}$ & 2004 & NA & NA \\
\hline House & LA & Hayes, James A. & $\mathrm{D}$ to $\mathrm{R}$ & 1995 & 1997 & Ran for Senate \\
\hline House & FL & Ireland, Andy P. & $\mathrm{D}$ to $\mathrm{R}$ & 1984 & 1993 & Retired \\
\hline House & $\mathrm{OK}$ & Jarman, John & $\mathrm{D}$ to $\mathrm{R}$ & 1975 & 1977 & Retired \\
\hline Senate & VT & Jeffords, James M. & $\mathrm{R}$ to I & 2001 & 2007 & Retired \\
\hline House & $\mathrm{TX}$ & Laughlin, Greg H. & $\mathrm{D}$ to $\mathrm{R}$ & 1995 & 1997 & $\begin{array}{l}\text { Lost General } \\
\text { Election }\end{array}$ \\
\hline Senate & CT & Lieberman, Joseph I. & D to ID & 2006 & NA & NA \\
\hline House & CA & Martínez, Matthew G. & $\mathrm{D}$ to $\mathrm{R}$ & 2000 & 2001 & $\begin{array}{l}\text { Lost General } \\
\text { Election }\end{array}$ \\
\hline House & MA & Moakley, John J. & ID to $\mathrm{D}$ & 1973 & 2001 & Died in Office \\
\hline Senate & OR & Morse, Wayne L. & $\mathrm{R}$ to I to $\mathrm{D}$ & 1957 & 1969 & $\begin{array}{l}\text { Lost General } \\
\text { Election }\end{array}$ \\
\hline House & MS & Parker, Michael & $\mathrm{D}$ to $\mathrm{R}$ & 1995 & 1999 & $\begin{array}{l}\text { Retired, Ran for } \\
\text { Governor }\end{array}$ \\
\hline House & NY & Peyser, Peter A. & $\mathrm{R}$ to $\mathrm{D}$ & 1977 & 1983 & $\begin{array}{l}\text { Lost General } \\
\text { Election }\end{array}$ \\
\hline House & NY & Reid, Ogden R. & $\mathrm{R}$ to $\mathrm{D}$ & 1972 & 1975 & Ran for Governor \\
\hline House & MI & Riegle, Donald W. Jr. & $\mathrm{R}$ to $\mathrm{D}$ & 1973 & 1976 & Ran for Senate \\
\hline House & AR & Robinson, Tommy F. & $\mathrm{D}$ to $\mathrm{R}$ & 1989 & 1991 & Ran for Governor \\
\hline House & NY & $\begin{array}{l}\text { Roosevelt, Franklin D. } \\
\text { Jr. }\end{array}$ & L to $\mathrm{D}$ & 1951 & 1955 & Ran for Governor \\
\hline Senate & AL & Shelby, Richard C. & $\mathrm{D}$ to $\mathrm{R}$ & 1994 & NA & NA \\
\hline Senate & PA & Specter, Arlen & $\mathrm{R}$ to $\mathrm{D}$ & 2009 & 2011 & $\begin{array}{l}\text { Lost Primary } \\
\text { Election }\end{array}$ \\
\hline House & AZ & Stump, Robert L. & $\mathrm{D}$ to $\mathrm{R}$ & 1983 & 2003 & Retired \\
\hline House & LA & Tauzin, Billy J. & $\mathrm{D}$ to $\mathrm{R}$ & 1995 & 2005 & Retired \\
\hline Senate & SC & Thurmond, J. Strom & ID to $\mathrm{D}$ to $\mathrm{R}$ & 1964 & 2003 & Died in Office \\
\hline House & OK & Watkins, Wesley W. & $\mathrm{D}$ to $\mathrm{R}$ & 1996 & 2003 & Retired \\
\hline House & SC & Watson, Albert W. & $\mathrm{D}$ to $\mathrm{R}$ & 1965 & 1971 & Ran for Governor \\
\hline
\end{tabular}

$\dagger$ For members who switch multiple times, the date of their caucus switch is reported.

Source: Biographical Directory of the United States Congress

Other factors that might have a more significant impact on the sample include age and the length of tenure party switchers possess. It is by no means clear that a switcher's age or tenure should affect the degree of environmental change he experiences, but one could speculate that an effect exists. If one observed, for example, that primarily older, more senior legislators changed parties, a theory suggesting that observed differences between the pre- and post-switch periods are the result of abnormal behavior prompted by the anticipation retirement would have some empirical support. However, no such trend exists. The descriptive data for party switchers over the past several decades 
suggest that their ages and durations of tenure are roughly in line with the rest of their chambers.

Table 2. Senate Switchers’ Age at the Time of Defection

\begin{tabular}{ccc}
\hline State & Name & Age at switch \\
\hline VA & Byrd, Harry F. Jr. & 55 \\
CO & Campbell, Ben Nighthorse & 61 \\
VT & Jeffords, James M. & 67 \\
CT & Lieberman, Joseph I. & 64 \\
OR & Morse, Wayne L. & 54 \\
AL & Shelby, Richard C. & 60 \\
PA & Specter, Arlen & 79 \\
SC & Thurmond, Strom J. & 61 \\
\hline & Mean & $\mathbf{6 2 . 6}$ \\
& Grand Mean for Chamber & $\mathbf{6 1 . 2}$ \\
& (108th-111th Congress) & $\mathbf{1 . 4}$ \\
\hline
\end{tabular}

Sources: Biographical Directory of the United States Congress and Vital Statistics on Congress

As table 2 shows, at the time they defect, Senate switchers are, on average, a little more than 62 years old, about a year older than the average member of their chamber. House switchers are slightly younger than their colleagues on average. The average party switcher in the House is just under 51 years old at the time he switches, about four and a half years younger than his average colleague. 
Table 3. House Switchers’ Age at the Time of Defection

\begin{tabular}{|c|c|c|}
\hline State & Name & Age at switch \\
\hline LA & Alexander, Rodney & 57 \\
\hline AR & Alford, Thomas D. & 44 \\
\hline $\mathrm{PA}$ & Atkinson, Eugene V. & 54 \\
\hline GA & Deal, J. Nathan & 52 \\
\hline NJ & Dellay, Vincent J. & 50 \\
\hline $\mathrm{PA}$ & Foglietta, Thomas M. & 52 \\
\hline NY & Forbes, Michael P. & 47 \\
\hline VA & Goode, Virgil H. Jr. & 53 \\
\hline TX & Gramm, W. Philip & 40 \\
\hline FL & Grant, J. William & 45 \\
\hline AL & Griffith, Parker & 67 \\
\hline $\mathrm{TX}$ & Hall, Ralph M. & 80 \\
\hline LA & Hayes, James A. & 38 \\
\hline FL & Ireland, Andy P. & 53 \\
\hline OK & Jarman, John & 59 \\
\hline TX & Laughlin, Greg H. & 53 \\
\hline CA & Martínez, Matthew G. & 71 \\
\hline MA & Moakley, John J. & 45 \\
\hline MS & Parker, Michael & 46 \\
\hline NY & Peyser, Peter A. & 55 \\
\hline NY & Reid, Ogden R. & 46 \\
\hline MI & Riegle, Donald W. Jr. & 35 \\
\hline AR & Robinson, Tommy F. & 47 \\
\hline NY & Roosevelt, Franklin D. Jr. & 46 \\
\hline AZ & Stump, Robert L. & 54 \\
\hline LA & Tauzin, Billy J. & 52 \\
\hline OK & Watkins, Wesley W. & 57 \\
\hline \multirow[t]{4}{*}{ SC } & Watson, Albert W. & 42 \\
\hline & Mean & $\overline{53.9}$ \\
\hline & $\begin{array}{l}\text { Grand Mean for Chamber } \\
\text { (108th-111th Congress) }\end{array}$ & 55.4 \\
\hline & Difference & -1.5 \\
\hline
\end{tabular}

Sources: Biographical Directory of the United States Congress and Vital Statistics on Congress

Similarly, there is no strong trend in the length of time party switchers spend in office before deciding to switch. Table 5 shows that at the time they defect, House switchers are slightly less tenured than the average House representative, and Senate switchers are slightly more tenured. Table 4 demonstrates that senators who switch parties have served an average of nearly 12 years in the chamber at the time they change affiliation. This makes them a little more than a year more senior than their average colleague. 
Table 4. Senate Switchers' Tenure at the Time of Defection

\begin{tabular}{ccr}
\hline State & Name & Years of Service $\dagger$ \\
\hline VA & Byrd, Harry F. Jr. & 5 \\
CO & Campbell, Ben Nighthorse & 2 \\
VT & Jeffords, James M. & 12 \\
CT & Lieberman, Joseph I. & 17 \\
OR & Morse, Wayne L. & 12 \\
AL & Shelby, Richard C. & 7 \\
PA & Specter, Arlen & 28 \\
SC & Thurmond, J. Strom & 11 \\
& Mean & $\mathbf{1 1 . 8}$ \\
& Grand Mean for Chamber & $\mathbf{1 0 . 6}$ \\
& (1953-2007) & $\mathbf{1 . 2}$ \\
\hline
\end{tabular}

†Years of service at the time the party switch occurred.

Sources: Biographical Directory of the United States Congress \& cite Vital Statistics on Congress

\begin{tabular}{|c|c|c|}
\hline State & 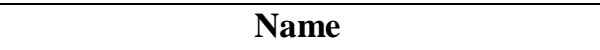 & Terms $\dagger$ \\
\hline LA & Alexander, Rodney & 1 \\
\hline $\mathrm{AR}$ & Alford, Thomas D. & 1 \\
\hline $\mathrm{PA}$ & Atkinson, Eugene V. & 2 \\
\hline GA & Deal, J. Nathan & 2 \\
\hline NJ & Dellay, Vincent J. & 1 \\
\hline PA & Foglietta, Thomas M. & 1 \\
\hline NY & Forbes, Michael P. & 3 \\
\hline VA & Goode, Virgil H. Jr. & 2 \\
\hline TX & Gramm, W. Philip & 3 \\
\hline FL & Grant, J. William & 2 \\
\hline $\mathrm{AL}$ & Griffith, Parker & 1 \\
\hline $\mathrm{TX}$ & Hall, Ralph M. & 12 \\
\hline LA & Hayes, James A. & 5 \\
\hline FL & Ireland, Andy P. & 4 \\
\hline OK & Jarman, John & 13 \\
\hline $\mathrm{TX}$ & Laughlin, Greg H. & 4 \\
\hline CA & Martínez, Matthew G. & 10 \\
\hline MA & Moakley, John J. & 1 \\
\hline MS & Parker, Michael & 4 \\
\hline NY & Peyser, Peter A. & 4 \\
\hline NY & Reid, Ogden R. & 5 \\
\hline MI & Riegle, Donald W. Jr. & 4 \\
\hline AR & Robinson, Tommy F. & 3 \\
\hline NY & Roosevelt, Franklin D. Jr. & 2 \\
\hline AZ & Stump, Robert L. & 4 \\
\hline LA & Tauzin, Billy J. & 9 \\
\hline OK & Watkins, Wesley W. & 8 \\
\hline \multirow[t]{4}{*}{ SC } & Watson, Albert W. & 2 \\
\hline & $\begin{array}{l}\text { Mean } \\
\end{array}$ & 4.0 \\
\hline & Grand Mean for Chamber (1953-2007) & 5.3 \\
\hline & Difference & -1.3 \\
\hline
\end{tabular}

†Terms at the time the party switch occurred.

Sources: Biographical Directory of the United States Congress and Vital Statistics on Congress. 
The average House switcher has served just over four terms ${ }^{3}$ when he defects, making him just over a term more junior than his average colleague. These figures suggest that although the sample does not perfectly mirror the rest of the chamber, the differences in age and tenure are not systematic. The disparities conflict depending on which chamber one examines, and they are relatively small in scale.

\section{Cases}

Although they may be "rare birds” (Nokken 2005), congressional party switchers have not been uniform in their geographic origins. Partisan realignment of southern conservatives clearly played a major role in the large number of defections of the mid1990s. Realignment brought conservative southern MCs the opportunity to switch parties with relative ease, credibly claiming that they were responding to the changing ideological composition of the parties. The Republican takeover of Congress in 1994 offered them a reason to switch. Switchers generally received better committee assignments, retained their seniority, and remained members of the majority.

This southern phenomenon accounts for a major part of the history of congressional party switchers, but it is far from the whole story. As table 1 illustrates, party switching has not been an exclusively southern phenomenon in the post-World War II Congress. In those sections of this project requiring more in-depth analysis, I have primarily focused on the experiences of Rodney Alexander (LA), Eugene Atkinson (PA), Harry Byrd Jr. (VA), Ben Nighthorse Campbell (CO), Nathan Deal (GA), Michael

\footnotetext{
${ }^{3}$ Because the number of terms a Senator has served is a somewhat imprecise measurement of tenure (treating and entire six-year period as one unit), I use terms only when discussing House members. For Senators, I measure their tenure using years in office.
} 
Forbes (NY), Virgil Goode Jr. (VA), Peter Peyser (NY), Richard Shelby (AL), and Arlen Specter (PA). 


$$
\left(\begin{array}{c}
\text { “As a Democrat, I had about } 95 \text { percent of } \\
\text { the African-American vote. As an } \\
\text { independent that fell down to } 20 \text { percent, and } \\
\text { as a Republican...probably } 10 \text { percent." }
\end{array}\right)
$$

\section{Fundraising, Geographic Constituencies, and Party}

The degree to which a legislator's fundraising efforts and reelection constituency are influenced by his party affiliation can go a long way toward answering key questions about the power of partisanship. The notion that reelection constituencies influence legislative behavior is an old one with ample evidence to support it (e.g., Arnold 1990; Bartels 1991; Fenno 1978; Fiorina 1974; Mayhew 1974; Miller and Stokes 1963; Wright 1989). Studies concerned with the ties between campaign finances and members' behavior are more ambiguous, but some analyses have found that contributions buy interest groups greater access to officials (e.g., Austen-Smith 1995; Grenzke 1989; Wright 1990) as well as greater effort on the part of legislators (Evans 1996; Hall and Wayman 1990). Given these findings, it is reasonable to suggest that major shifts in reelection constituency, fundraising portfolios, or both are likely to have some substantial impact on legislative performance.

Two key electoral questions about party switchers concern (1) whether party has an impact independent of the candidate's identity and perceived ideology and (2) when and how any such effect should be expected to be substantial. Scholars have long known that much of individual voting behavior can be linked to voters' party identification (e.g., Campbell et al. 1960). The extent to which voters in different regions rely on party identification rather than their impressions of the candidate has the potential to provide

\footnotetext{
${ }^{4}$ Good, Virgil. Telephone interview. March 20, 2010.
} 
significant information about the strength of party as a brand name in those areas. Regional socio-political variation, in turn, provides the opportunity to examine the characteristics in which a party switch prompts large or small shifts in electoral support. In order to analyze changes in geographic constituency, I simply observe the regional variation in candidates' electoral support, examining the last election before the switch and the first election afterward.

This approach generally produces the greatest potential for meaningful results because, although many congressional elections are not competitive, the first election following a party switch usually is. It would be difficult to discern changes in voter support in elections that involve either no major-party challenger or a "poor quality" challenger whose electoral support is minimal.

Concerning corporate donations, the overall trend for PAC donations among Democrats switching to the Republican Party is clear. They tend to receive a larger percentage of their funding from corporate PACs with the Republican Party than they did as Democrats. Figure 1 shows the average percentage of a candidate's overall fundraising portfolio comprised of corporate PAC donations. These data were generated from fundraising averages for the pre- and post-switch periods. The positive effect of Republicanism on corporate PAC receipts is apparent in the cases of 12 of the 16 MCs named in figure 1, and in those cases the change is often pronounced. 
Figure 1. Corporate Receipts for Party Switchers

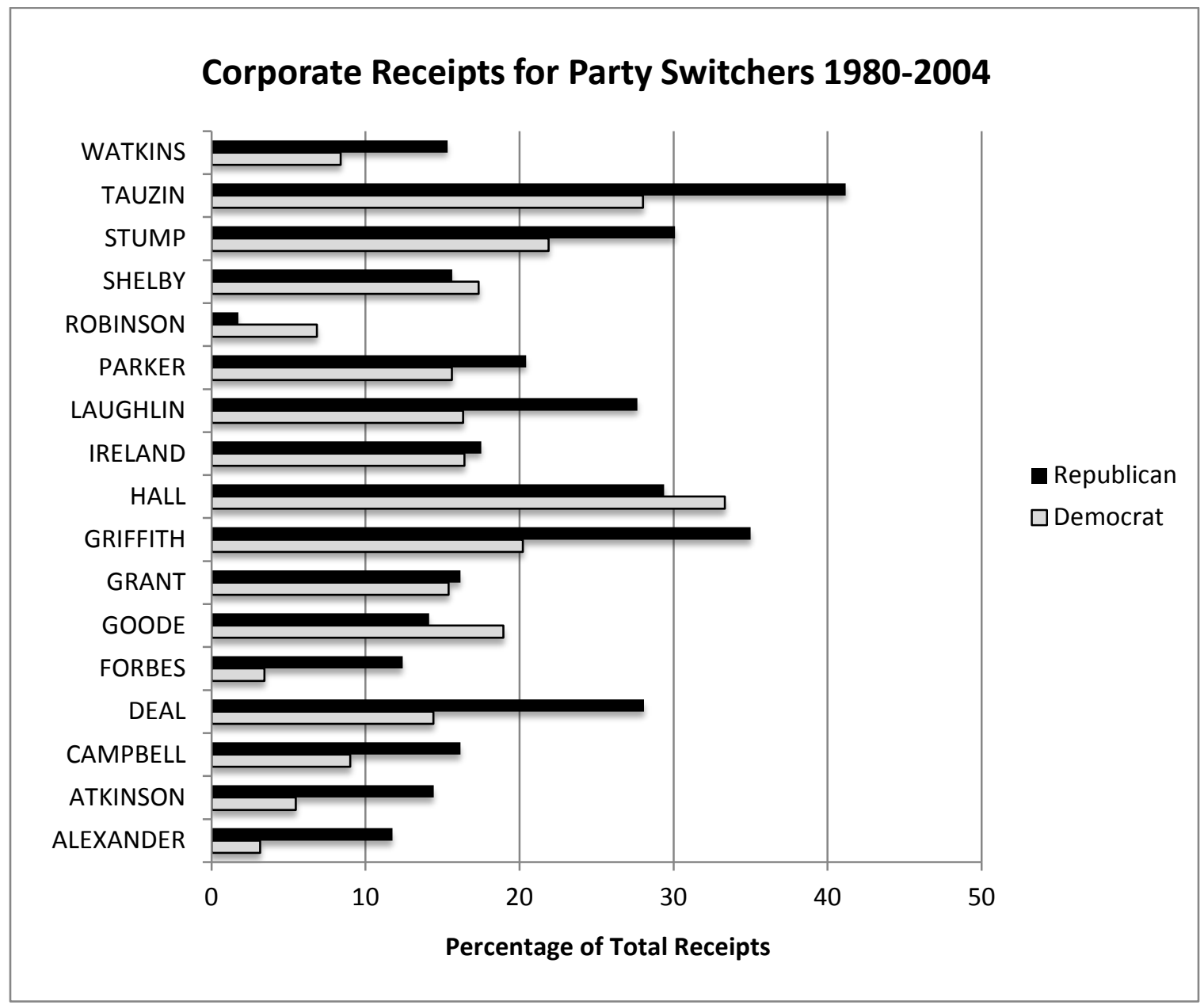

Source: Federal Election Commission

The only members to experience a relatively large drop in corporate donations after becoming Republicans were Representatives Virgil Goode (VA), Ralph Hall (TX), and Tommy Robinson (AR). Each of these members saw corporate donations drop by 5 to 10 percent as a percentage of their overall PAC contributions. In the only other case defying my hypothesis, Sen. Richard Shelby (AL) experienced a slight decline in corporate funding but retained at least roughly the level of corporate support he had enjoyed to that point. 
Figure 1 displays a trend that suggests (although not overwhelmingly in each individual case) that members tend to receive a greater proportion of their funding from corporate sources as Republicans than they did as Democrats. Although this evidence says little if anything about possible changes in switchers' fundraising strategies, the trend seems to indicate that legislators' party identifications have some influence on the role of corporate PACs in their fundraising efforts. These data are somewhat limited. Ideally the data set should include more members who switched from Republican to Democrat. The only such person for whom FEC data are available is Rep. Michael Forbes (NY). This is an inherent limitation of the data, but it worth noting that his case follows the same trend as the majority. After becoming a Democrat, his corporate receipts fell about 9 percent (from about 12.4 percent to about 3.4 percent of total PAC receipts). 
Figure 2. Labor Receipts for Party Switchers

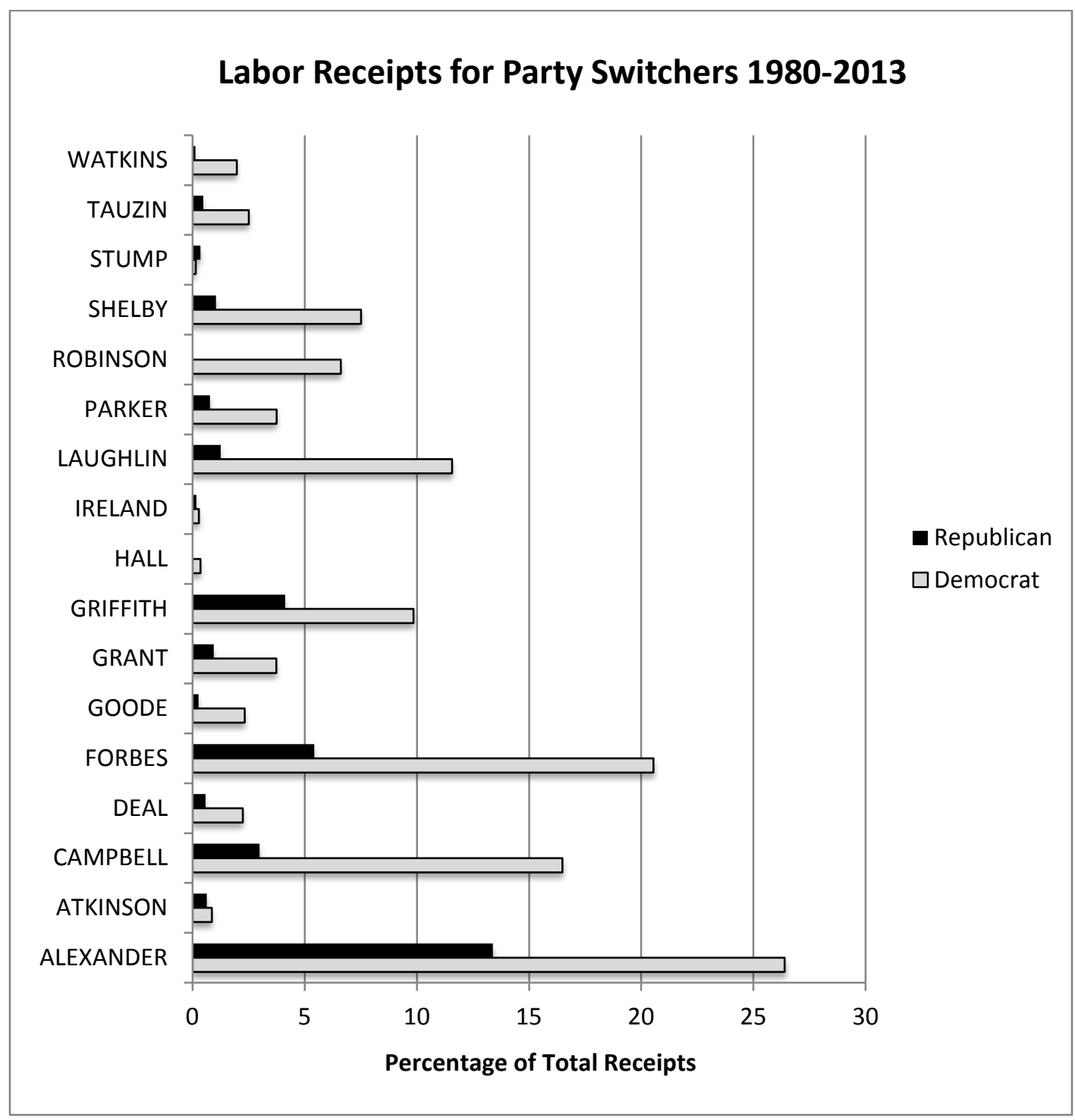

Source: Federal Election Commission

The trend for party switchers' labor PAC receipts is even clearer. Only in 1 case out of 16 did a member receive more labor donations as a Republican than as a Democrat. The case is that of Rep. Bob Stump (AZ), and the difference between his preand post-switch labor receipts is miniscule. For those who experience particularly noticeable shifts in labor support, the change can be on the order of almost 20 percent of a member's overall campaign receipts. 
The potential for such a shift should be of interest not only for MCs contemplating a switch (who must in many cases consider how to replace a massive chunk of their campaign receipts) but also for those wishing to understand the relationship of partisanship to campaign finance. Most scholars of Congress would suspect that corporate and labor funding follow these general trends for average members of Congress. They might not expect, however, that this effect is apparent even for a single member acting under different party labels. I argue that this evidence suggests that the disparate sources of support members receive are based at least in part on partisanship. The effects of partisanship on member behavior may manifest in the incentive structures party leaders establish, or they may emerge as the result of constituency composition, which affects members' induced preferences. The fundraising dimension of this story is only one piece, but it is an important one. If one wishes to address the question of how partisanship affects politicians, one key element is where their funding comes from and, by extension, to which donors they are potentially answerable.

Individual contributions are not examined here for a simple reason: the distinction between pro-labor and pro-corporate interests breaks down in the reporting of individual contributions. A member of a carpenter's union pays dues and may even contribute money to the union's PAC, but when he or she makes an individual campaign contribution that connection to organized labor disappears in the paperwork. Because union members are not required to disclose that relationship, the potential effect of unions on individual contributions is essentially unobservable without conducting a poll of individual donors. Those individuals are, however, required to report the identity of their 
employers. That same union carpenter will report the name of the company for which he or she works, and the result is that every candidate's individual contribution portfolio appears to be dominated by business rather than by labor interests. The result is that, if one were to compare individual contributions for party switchers before and after they switch, one would find high and relatively constant levels of support among business groups. If one examines a measure that combines PAC and individual contributions, it is generally still clear that there is a difference between the pre- and post-switch figures, but that difference (in terms of percentage) is diluted by the addition of a relative constant: the individual contributions. Accordingly, I examine PAC contributions here because they offer the potential to distinguish between two groups with political goals that are fundamentally at odds.

\section{Cases}

\section{Ben Nighthorse Campbell}

Senator Campbell was first elected in 1986 as a Democratic representative of Colorado's 3rd congressional district, which encompasses most of western Colorado. He served three terms in the seat before successfully running for U.S. Senate in 1992 to replace fellow Democrat Tim Wirth. By winning that election, he became the first American Indian to serve in the U.S. Senate in decades and the eighth in history. Campbell served only the first two years on his Senate term as a Democrat, switching to the Republican Party in 1995. He ran successfully for reelection in 1998 but did not seek a third term in 2004. Like most other switchers, Campbell spent a significant amount of energy (and prompted an equally significant amount of media attention) touting his position as a moderate and framing the switch as evidence of his maverick status, a claim 
that he sought to reinforce in several photos sitting atop his Harley Davidson motorcycle. There was never any question that Campbell stood out from among his fellow senators as a distinctive character. Not only was Campbell the only Native American in the Senate and a motorcycle enthusiast, but he was also well known for being a jeweler and having captained the 1964 U.S. men’s Olympic judo team (Carlin 1995).

In the weeks leading up to Campbell's defection, he had been a strong Democratic defender of the balanced-budget constitutional amendment at the heart of the Republican Contract with America. Ultimately the amendment failed in the Senate by a two-vote margin with all Republicans and 14 of 47 Democrats supporting the measure. According to Campbell, who was generally considered a fiscal conservative, the Democratic failure to support the bill pushed him past his breaking point. The amendment failed to pass on March 2, 1995, and less than a day later Campbell was standing in front of reporters with Senate Majority Leader Bob Dole discussing his decision to become a Republican. In that statement he was quite clear that the decision came as a direct result of the Democratic opposition to the proposed amendment (Carlin 1995).

Public reaction to the switch from party leaders was relatively tame compared to that directed at other party switchers, but Senate Minority Leader Tom Daschle was quoted as saying that Campbell was joining an organization working to "annihilate many of the programs Ben Campbell has stood for all of his life.” For his part, President Bill Clinton focused on persuading the senator to continue supporting his agenda but also made a statement labeling Campbell’s decision a “mistake” (Carlin 1995). Campbell’s continued support of the Democratic agenda was compromised considerably, however, 
and MPR found that he was among the party switchers with the largest predicted changes in voting behavior.

Reports of Campbell's standing within the Democratic Party suggest that the rift that eventually culminated in his defection began with pro-development votes that upset environmental interest groups and with a public dispute involving his former chief of staff, Sherrie Wolff (Seelye 1995). Campbell publicly alleged that Wolff had been suffering from financial hardship in her run for secretary of state and had threatened to file a sexual harassment lawsuit against Campbell if he refused to continue paying her while she campaigned for the office (Margolis 1997). The claim was never substantiated, but there was widespread speculation that Democratic leaders blamed Campbell for Wolff's defeat (Carlin 1995; Margolis 1997).

It became clear soon after Campbell's switch that his staff had not taken the news well. Eleven of Campbell's 19 Capitol Hill staff, including his chief of staff, resigned shortly after the decision (Angwin 1995b). However, his electoral fortunes were not so bleak. In 1998, Campbell’s reelection succeeded by a much wider margin than his initial 1992 campaign. As a Democratic challenger, Campbell won by less than 10 percent of the vote, but as a Republican incumbent, his margin of victory was close to 30 percent over Democratic challenger Dottie Lamm. Lamm may have been considered something less than a "quality" challenger, but the lack of serious opposition to Campbell’s candidacy was also apparent in his 1998 Republican primary. In that contest he defeated his Republican challenger by an even wider margin than he would later have in the general election. Campbell's popularity soared enough during the late 1990s that rumors surfaced that he might attempt a run for Governor of Colorado, having defeated former 
Governor Dick Lamm (husband to Dottie Lamm) in the 1992 Democratic primary election.

Like many party switchers of the mid-1990s, Campbell received extra attention from his new party immediately following the decision. George $\mathrm{H}$. W. Bush delivered a speech at his first 1995 fundraising event, and Campbell received widespread support from his new party at both the federal and the state levels (Miniclier 1995). Shortly after making the switch, the senator touted having been asked to return only five campaign contributions (Angwin 1995a). However, the overall portfolio of contributions Campbell received changed dramatically. In the 1998 election, labor PACs gave Campbell just over a third of what they had in 1992, but corporate PACs gave more than three times as much in 1998 as in 1992. These changes are apparent both in the total quantities of funds received and in their percentage of total receipts.

Corporate PAC receipts accounted for about 9 percent of Campbell’s 1992 funds, but in 1998 that number grew to about 16 percent. Labor PAC contributions made up well over 16 percent of the senator's 1992 funds, but in 1998 that figure dropped to only 3 percent. Despite losing much of his union support, Campbell grew his fundraising capacity substantially between his first and second electoral bids. Although some of this expansion was likely due to his incumbent status in the second election, the speed with which Campbell expanded his fundraising operation undoubtedly contributed to his electoral success. Campbell more than doubled in total fundraising effort between his 1992 and 1998 campaigns. The difference was largely accounted for by increases in corporate PAC funds and individual contributions. 
Figure 3. Changes in vote share Ben Campbell experienced after becoming a Republican Colorado

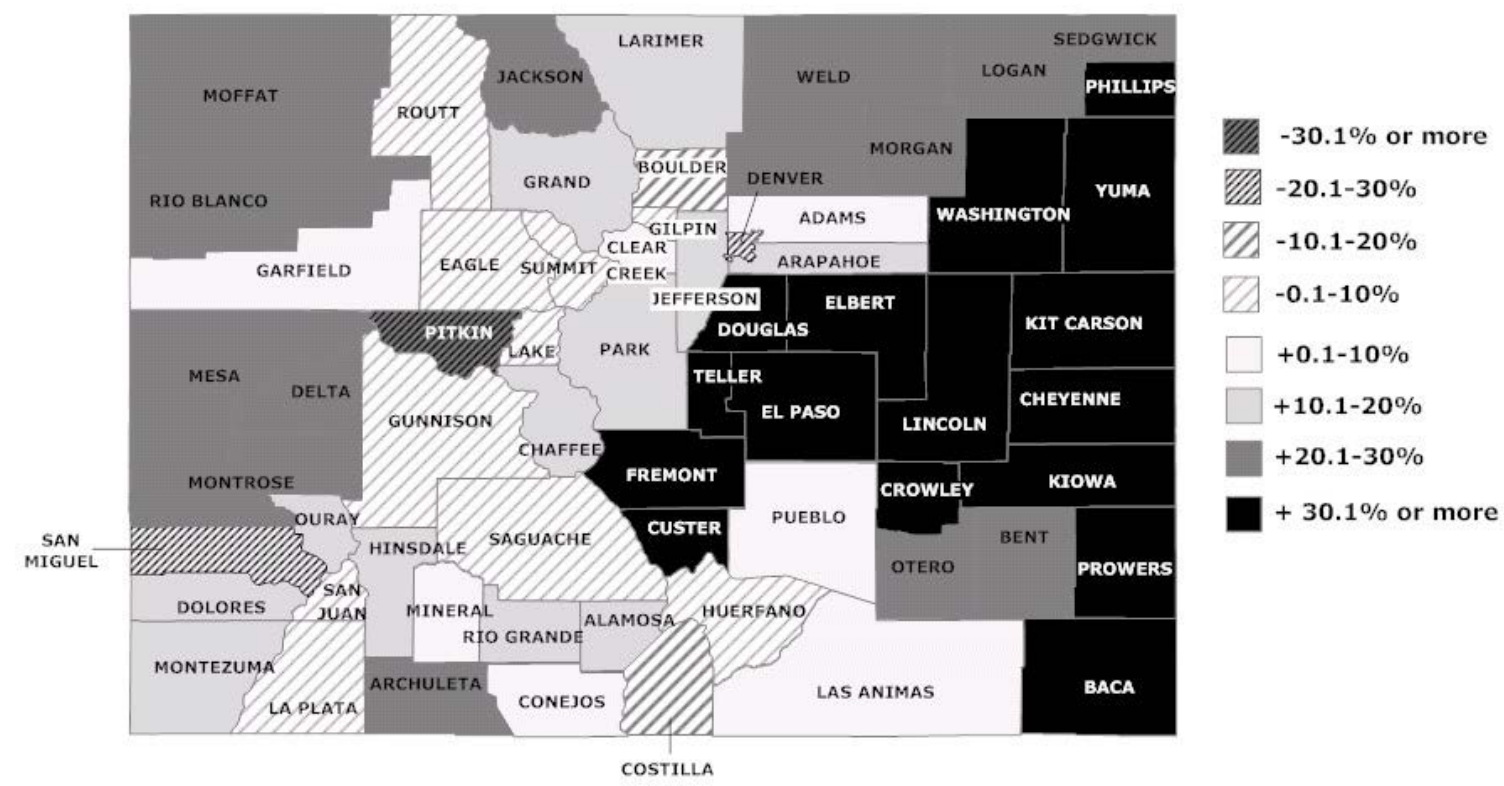

Source: Colorado Secretary of State

Figure 3 shows the dramatic shifts in geographic constituency that Ben Campbell experienced after deciding to switch parties. Many of the shifts in support followed the urban-rural divide that one might expect of a partisan shift. In many rural counties of eastern Colorado, Campbell received a boost in vote shares greater than 30 percent. In the urban districts of Denver and Boulder counties, he lost about 23 percent and 15 percent of the counties' respective votes compared to what he received Democrat. In Pitkin County, which contains the city of Aspen, Campbell's vote share declined 35 percent. In more rural counties, however, Campbell gained as much as a 43 percent increase in support. The net balance of votes favored Campbell, but it is clear from this map that the geographic distribution of his reelection constituency changed dramatically following his reelection bid. 
As is true of all the switchers examined here, there is a strong and statistically significant $(p<.01)$ correlation between the average partisanship of the counties in question and the change in votes received in those regions. For Campbell, the change in votes received is positively correlated with Republican partisanship (the average percentage of votes received in each county by Republican presidential candidates), yielding a Pearson's $R$ of 0.88 . Among the successes Alexander experienced on the campaign trail in 1998 was the continued endorsement of the Denver Post. To this he added a new endorsement by the more conservative Rocky Mountain News, which had endorsed his primary and general election opponents in $1992 .^{5}$

\section{Rodney Alexander}

Louisiana insurance agent, businessman, and state representative Rodney Alexander was first elected to the House as a Democrat in 2002. He won a seat representing Louisiana’s 5th congressional district, a largely rural northeastern district that includes the city of Monroe, and he did so by a narrow margin. In his first electoral effort, Alexander received almost 29 percent of the vote, with most of the rest of the votes split between three Republican candidates (who collectively garnered more than 66 percent of the vote). In a runoff Alexander edged his opponent by about half of a percent. He served most of his first term as a Democrat, but he clearly saw an electoral opportunity in a move across the aisle and took a strategic approach to the timing of his switch.

\footnotetext{
${ }^{5}$ Currently, newspaper endorsements go to the incumbent about $90 \%$ of the time (Ansolabehere, Lessem, and Snyder 2006). It is possible that the Rocky Mountain News decided to begin endorsing Campbell because of his status as an incumbent, not as a Republican. Of course, one cannot be certain what the paper would have done had Campbell remained a Democrat.
} 
Alexander publicly toyed with the idea of crossing the aisle in early 2004, but he backed off this rhetoric when U.S. Senator John Breaux (D-LA) began suggesting that Louisiana Democrats mount a serious challenge to Alexander (Alpert 2004). As late as March 18, 2004, Alexander vehemently denied that he had any intention to change parties. On that date he wrote a letter to constituents in his district in which he said that a move to the Republican Party would be impossible for him because the party "ignores the people that make this country great" and has led an "attack on the most fundamental rights that labor unions have worked decades to establish” (Nieves 2004). The potential conflict died down substantially over the ensuing months, but Alexander announced his intention to run as a Republican just an hour before the deadline for declaring one's candidacy. As a result, Louisiana Democrats did not have the time required to recruit a quality candidate to mount a significant challenge to Alexander in 2004.

By adopting the tactics he did, Alexander took a serious risk that voters would respond negatively to arguably underhanded methods, but he also effectively overcame the first hurdle for any party switcher: being reelected for the first time under a new party label. The anger Alexander's maneuvering caused among Democratic officials was undeniable. In one interview the chair of the state Democratic Party went so far as to call the congressman "Benedict Arnold” (Maginnis 2004). In another, he said, "Judas was offered 30 pieces of silver. I wonder how much Rodney Alexander got,” clearly implying that Alexander received some kind of payoff for his defection (Hurt 2004).

Rep. Bob Matsui, the chair of the Democratic Congressional Campaign Committee, called Alexander's party switch a "calculated and cowardly act of personal advancement.” Alexander's Washington office staff was similarly upset by the decision 
and collectively chose to resign (Broder 2004). The voters of the 5th district, however, had a different response. Alexander faced challengers from both parties in 2004, but he won nearly 60 percent of the vote, avoiding a runoff.

Although Alexander did not run his entire 2004 campaign as a Republican, his early cues that he might switch may have prompted environmental changes earlier than the date of his official switch. It is also noteworthy that the timing of Alexander's switch still afforded him about 3 months to campaign as a Republican. During his first term in office, Alexander expanding his fundraising capacity considerably, garnering more than $\$ 500,000$ more in total receipts as an incumbent Republican than he had as a Democratic challenger. However, his funding came from different sources in his second campaign than they had in his first.

In 2004, despite his efforts to appease labor groups prior to his switch, Alexander received \$41,500 less from labor PACs than he did as a Democratic challenger in 2002. As a result, his fundraising portfolio changed dramatically. Alexander originally received more than 26 percent of his funding from labor groups, but as a Republican that proportion dropped to less than 14 percent. By contrast, Alexander received more than a $\$ 130,000$ bump in corporate donations in 2004 than in 2002, changing the percentage of corporate funds he received from about 3 percent to more than 11 percent. In addition to losing much of his labor funding, he lost other support from labor unions, who changed their ratings of his performance. As table 6 shows, the AFL-CIO, United Auto Workers, and numerous other prominent labor unions dramatically reduced their estimations of Alexander's support for labor in the first year following the switch, a trend that persisted in subsequent years. 
Table 6. Changes in Rodney Alexander’s Labor Union Performance Ratings

\begin{tabular}{lccc} 
& \multicolumn{2}{c}{ Alexander's } & \\
Labor Group & Performance Ratings & \\
\hline United Auto Workers & $\mathbf{2 0 0 4}$ & $\mathbf{2 0 0 5}$ & Difference \\
\hline Transportation Communications Union & $60 \%$ & $14 \%$ & $-46 \%$ \\
Service Employees International Union & $67 \%$ & $0 \%$ & $-67 \%$ \\
\hline International Brotherhood of Boilermakers & $71 \%$ & $6 \%$ & $-65 \%$ \\
$\begin{array}{l}\text { International Association of Machinists and Aerospace } \\
\text { Workers }\end{array}$ & $75 \%$ & $25 \%$ & $-50 \%$ \\
$\begin{array}{l}\text { American Federation of State, County \& Municipal } \\
\text { Employees }\end{array}$ & $71 \%$ & $0 \%$ & $-71 \%$ \\
$\begin{array}{l}\text { American Federation of Labor and Congress of Industrial } \\
\text { Organizations }\end{array}$ & $75 \%$ & $0 \%$ & $-75 \%$ \\
American Federation of Government Employees & $80 \%$ & $13 \%$ & $-67 \%$ \\
\hline & & & \\
\end{tabular}

Changes in Alexander's geographic support were fairly dramatic as well. Figure 4 shows the difference between his vote share in his 2002 runoff election as a Democrat and the average of his next two general elections as a Republican. Had the general election results from 2002 been used to create the figure, the gains would have been greater and the losses smaller, owing to his 29 percent vote share in that contest. However, considering that the 2002 general election was a seven-person race, the runoff contest seems a more apt comparison to his subsequent three- and four-candidate races. The figure shows that Alexander's main losses were in the parishes of Allen, Iberville, and Pointe Coupee. The latter two of these make up the western suburbs of Baton Rouge and have higher percentages of African American residents than average—about 51 and 38 percent respectively (U.S. Census Bureau 2008). Regardless of which election one uses for these measurements, Alexander experienced profound gains in the more rural northern portion of his district. As is the case for the other switchers discussed here, 
Alexander's regional vote shifts were correlated with the average regional partisan presidential vote.

Figure 4. Changes in vote share Rodney Alexander experienced after becoming a Republican

\section{Louisiana's 5th Congressional District}

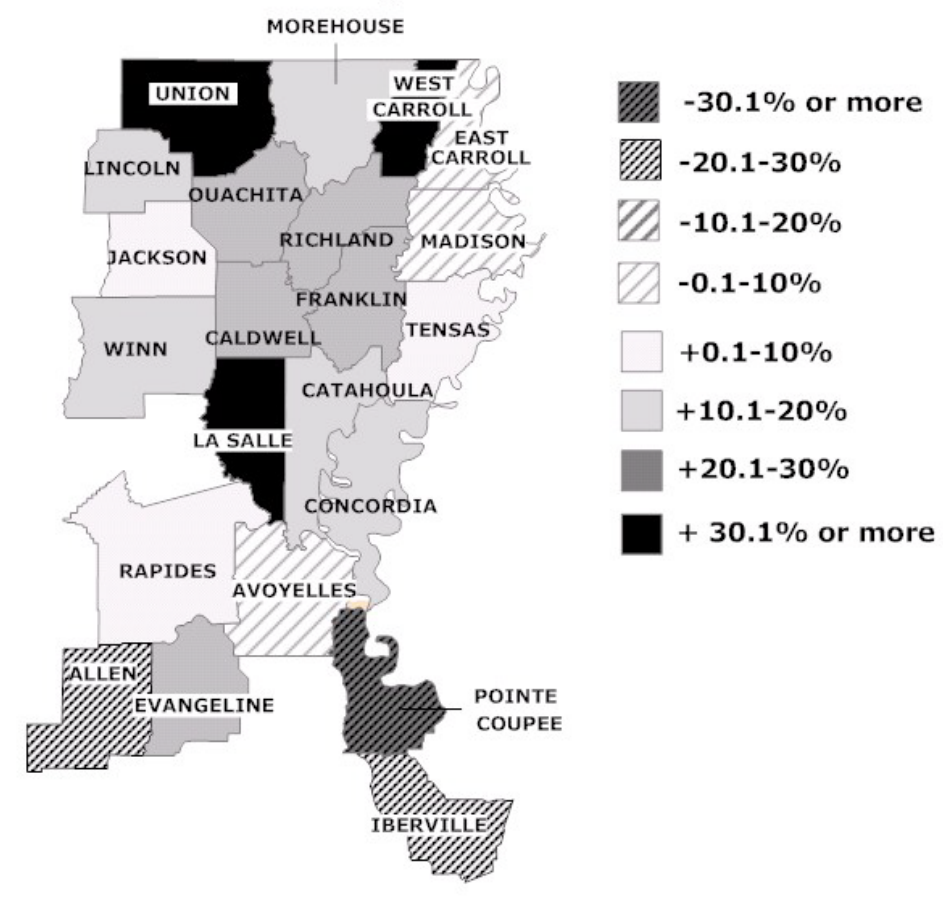

Source: Louisiana Secretary of State

Environmental shifts experienced by Rodney Alexander were strong both inside and outside Washington. Not only did Alexander coast to victory in 2004 and increase his total fundraising by more than 60 percent, but upon beginning his second term in January of 2005 he also received a seat on the House Appropriations Committee. Like most other switchers analyzed here, Alexander insisted he was not guaranteed this assignment. Other Republican sources, however, confirmed that Alexander was told he would receive "serious consideration" for the committee assignment (Alpert 2005).

\section{Nathan Deal}


Lawyer Nathan Deal was first elected in 1992 to represent Georgia’s 9th congressional district, a rural district covering much of northwest Georgia just south of Chattanooga, Tennessee. In his 1992 electoral bid Deal did quite well, garnering more votes in his district than either Bill Clinton or then-governor Zell Miller. Although he identified as pro-choice, from the beginning of his time in office, Deal's views placed him firmly in the position of a moderate Democrat. Deal supported abortion rights, but he also publicly endorsed several issue positions that later became part of the Republicans' Contract with America. As a Democrat, Deal helped form the Nonpartisan Coalition (sometimes simply called "the Coalition"), a group of more than 20 moderate legislators of both parties who worked to advocate bipartisan legislation (Christensen 1995a). One of Deal's early moments of notoriety came when he sponsored an amendment that offered an alternative to the Republican welfare reform bill. The measure fell 13 votes short of passage, but it marked a major legislative alternative proposed by a second-term congressman.

Anecdotal evidence suggests that Deal began to consider changing parties soon after arriving in Washington. In the weeks prior to switching parties, he met frequently with top congressional Republicans such as fellow Georgians Newt Gingrich and Sen. Paul Coverdell to discuss the possibility (Christensen 1995b). Rep. Deal won his 1994 election as an incumbent Democrat, but on April 10, 1995, he officially switched parties. Deal experienced a spike in total campaign receipts following his defection, but this effect held for only the 1996 election, after which his fundraising consistently fell short of what he had raised as a Democrat. Excluding 1996, in the subsequent four elections Deal raised an average of only about 67 percent as much money as he had as a Democrat. 
This decline in fundraising likely had more to do with Deal's electoral dominance than with declining support. After switching to Republican status, Deal never faced another close congressional race. His continued success put him in position to seek higher office, and in 2010, after a close Republican primary, Deal became the 82nd governor of Georgia, with 53 percent of the statewide vote (Georgia Secretary of State 2010).

After becoming a Republican, Deal made a point of reporting that he never spoke to anyone in the Republican Party about committee assignments or a transfer of seniority (Christensen 1995b). Legislators and their staffs tend to suggest that such deals were common among party switchers and party leaders during this period, but most insist that such negotiations did not occur in their own case. However, most switchers who enjoyed continued electoral success also received fortuitous committee assignments. In Deal's case, although claiming to negotiate neither for a better committee assignment nor for a transfer of seniority, he attained both. A few months into Deal's first term as a Republican, the party expanded the membership of the Commerce committee, making Deal the eighteenth ranked Republican on the committee.

Figure 5. Changes in vote share Nathan Deal experienced after becoming a Republican

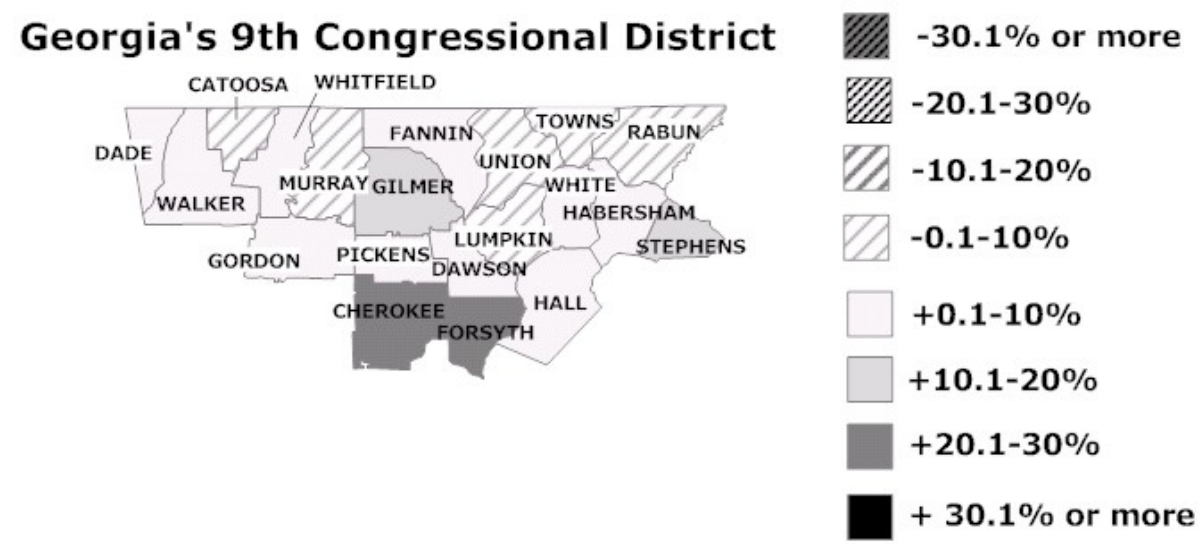

Source: Georgia Secretary of State 
Unlike some other party switchers, Deal's defection resulted in a relatively mild change in geographic constituency. Although he saw gains of more than 20 percent in two southern counties, the majority of the district remained relatively constant. He either gained or lost less than 10 percent of the vote share in most counties. One possible explanation for the relatively low rate of geographic constituency change for Deal is the racial makeup of his district. While Deal held his congressional seat the 9th district had an African-American population of about 3.2 percent, well below the national average (U.S. Census Bureau 2000).

Deal's district was in many ways ideal for someone switching to the Republican Party. With a predominantly white, relatively conservative, and rural population, the transition from conservative Democrat to Republican cannot have been an overwhelming change for his constituents. In fact, the rest of the state's congressional delegation was undergoing a shift to the Republican Party at the same time. In 1994, the state's congressional delegation was composed of seven Democrats and four Republicans. By 1995, that number had changed to three Democrats and eight Republicans (Kellman 1995). The fact that Deal timed his switch to coincide with the move to a Republican majority may also have limited the backlash from his former party and secured him more favorable committee assignments. Under the Republican leadership Deal finally receive a seat on the Commerce committee. According to fellow party switcher Billy Tauzin, the seat was denied him under the Democratic regime based on his conservative voting record (Clines 1995). Other changes in Deal's electoral environment also ensued. Although it may not have mattered much to his new and old supporters, Deal's decision 
cost him the endorsements of both the Atlanta Journal Constitution and the Chattanooga Times in 1996.

Don Fowler, the chairman of the Democratic National Committee, publicly rebuked Deal for his decision. In a statement, Fowler said that Deal should step down and let the people decide his fate in a special election, a course of action taken by a few other party switchers, such as Phil Gramm. Fowler also accused Deal of “[doublecrossing] his constituents for his own political gain.” Deal had previously suggested he would resign and run again in a special election but later refused, saying that he had no recollection of making such a statement and wanted to spare the taxpayers the cost of such an election (Kellman 1995).

The Democratic leadership was clearly upset about Deal leaving, but they had little recourse. Unlike any other point in U.S. history, the upcoming electoral season meant the reelection attempts of several recent party switchers at once. A single party switcher might be a popular target for a majority party, determined to advance its agenda. A minority party, however, targeting several switchers, all of whom could credibly claim to have changed little and helped their constituents in the process, had much less incentive and firepower to take meaningful action. Ultimately, Deal was not particularly vulnerable in his district, and Democrats had to wait more than a year to challenge him. When they did, their candidate fell well short of unseating him.

\section{Michael Forbes}

First elected to New York’s 1st congressional district (in eastern Long Island) in 1994’s Republican Revolution, Michael Forbes initially earned a reputation as a supporter of Newt Gingrich. Forbes was widely considered an ideological conservative 
as well. He was three times rated an "A" by the National Rifle association; was endorsed by the Right to Life Party, a pro-life offshoot of New York's Republican Party; and was a vocal supporter of balancing the budget (Barry 1996). Not long after voicing his support for Gingrich, however, he was the first to oppose the speaker's bid for a second term in 1996 (Alvarez 2000). As a result, Forbes’s popularity with Republican leadership was likely short-lived. Democratic leaders in February 1999 told the press that Forbes's seat was one of the Republican seats they considered to be vulnerable going into the 2000 election cycle (Grunwald 1999). By May, Forbes was breaking with Republicans to support the bipartisan Shays-Meehan campaign finance reform bill (Mitchell 1999). In July of the same year, Forbes left the Republican majority to join the Democratic minority.

Forbes's exit from the party was characterized by harsh, adversarial rhetoric from both his camp and the Republican leadership. In the press conference in which he announced his intention to defect, Forbes described his former party as "angry, narrowminded, intolerant, uncaring, incapable of governing at all, much less from the center” (Dao 1999). He elaborated further to characterize the party as one that allowed itself to be "defined through the actions of extremists" (Dao 1999). This kind of rhetoric is perhaps unsurprisingly common in party switching events, as the decision to switch often involves a policy disagreement with the switcher's former party or a failure of working relationships within the caucus. The fallout generated by Forbes's decision was dramatic and prompted leaders from both parties to involve themselves in the 2000 race for the Long Island district. 
On the day of Forbes's switch, presidential hopeful Al Gore joined the chorus of Democratic leaders publicly applauding the move. Gore was quoted as saying that he believed Forbes to be a man of "principle and integrity" (Dao 1999). The day after the switch, the New York Times attempted to contact Forbes for comment but was unable to reach anyone in his office. Virtually the entire staff had resigned in protest; roughly 18 staffers quit between the district and Capitol Hill offices (Schmitt 1999). The congressman’s day-to-day operations were briefly disrupted before the county Democratic leader and two New York Democratic MCs provided Forbes with a transitional staff (McQuiston 1999).

Just prior to their respective primaries in 2000, Senator John McCain arrived in Long Island to "stump” on behalf of Forbes’s Republican opponent, Brookhaven town supervisor Felix Grucci. Bill Clinton appeared at a fundraiser in Manhattan on Forbes’s behalf, raising more than half a million dollars in support for the former Republican who had voted "yes" on all four articles of impeachment against him less than two years earlier. Republican leaders in both houses of Congress donated tens of thousands of dollars to Grucci's campaign (Alvarez 2000). When asked about Forbes in a New York Times interview, Thomas Davis III, chair of the House Republican Campaign Committee, joked, "Have you ever heard of the movie Dead Man Walking?...We're going to hit him pretty hard” (Alvarez 2000). Republicans even put together an attack ad featuring outtakes from an ad Forbes made as a Republican. The ad reportedly ended with Forbes making rude noises under his armpit. However, there is an absence of clear evidence that Republicans ever actually ran the ad (Alvarez 2000). 
Forbes ultimately lost his 2000 Democratic primary by less than 40 votes to Regina Seltzer, a 71-year-old environmental lawyer and former Brookhaven councilwoman ${ }^{6}$ (Kelley 2000a). Seltzer went on to lose to Grucci in the general election by more than 15 percent. Forbes ran as a Working Families Party candidate in the general election but received less than 5 percent of the vote. All party switchers make themselves somewhat vulnerable to allegations of ideological inconsistency, but Michael Forbes may have been especially susceptible to such claims. In addition to reportedly refusing the endorsement of the Right to Life Party in 2000 in what the press cast as a concession to Democratic leaders, Forbes publicly claimed not only that he was an advocated of gun control but that he always had been (Alvarez 2000). The NRA had been among Forbes's top 20 donors in 1998 and had twice endorsed him.

There is little doubt that Forbes's case is a strange one. Party switchers fail relatively frequently to secure reelection in their first post-switch contest, but Forbes's loss to a former town councilwoman in a primary election is likely a sign that he made himself particularly vulnerable. Also unusual was Forbes’s decision to switch to the minority party at a time when he would be alone in his transition. This set of circumstances (combined with apparent preference reversals by Forbes) may have put a bull's-eye on Forbes's back, but it also revealed the degree to which his defection upset party elites, including both staffers and legislative leaders. Republican Party leaders in the legislature appear to have focused their electoral resources on defeating Forbes and reclaiming his seat, a natural reaction to a vulnerable incumbent Democrat. However, leaders also considered publicly humiliating their former colleague with an embarrassing

\footnotetext{
${ }^{6}$ Forbes's primary defeat does not allow us to examine how his reelection constituency changed. It would make little sense to compare his closed primary results under two different party labels.
} 
television ad and alerted the media to the staff walkout, facilitating the publicity of a series of angry statements by former staffers (Schmitt 1999). This apparent animosity was countered by evident acceptance by Democrats. Bill Clinton clearly thought that the addition of a new Democrat and a one-seat gain in the House were worth disregarding (if only for a day) Forbes's decision to vote in favor of Clinton's impeachment.

\section{Richard Shelby}

Senator Richard Shelby (AL) had successful electoral campaigns in both 1986 and 1992 as a Democrat, but newspaper accounts suggest that he may have been accepted only grudgingly by Democratic elites in the state party as well as nationally. In fact, Shelby repeatedly and publicly clashed with the Clinton White House. In 1993, when the Clinton administration rolled out its economic plan, Shelby commented on the plan using the phrase "the taxman cometh" (Berke 1994). Later, Shelby invited television cameras to a meeting he was having with Vice President Gore, announcing that the plan was "high on taxes, low on cuts” (Rockwell 1993). Not long after these incidents, the administration reportedly tried to penalize Shelby by moving a small NASA office out of Alabama and denying Shelby extra tickets to a White House reception honoring the national champion University of Alabama football team. It is not completely clear that the White House thought these kind of slights would encourage Shelby to fall in line. Clinton may have seen reprimanding Shelby as an end in itself. It is clear from newspaper accounts, however, that Clinton was unhappy with Shelby's behavior and seemed to have expected more collegial treatment from a fellow Democrat.

Likely due to these kinds of incidents as well as a history of voting against Democrats on many issues, rumors had already surfaced that a party switch would be a 
possibility for the conservative southerner more than a year prior to his eventual switch to the GOP in 1994 (e.g., State News Service 1993). Perhaps because of his conservative reputation, the staff that he put together did not quit following his switch, at least not publicly. Shelby’s decision to become a Republican was widely reported in local and national media, but related news stories about the fallout of that decision were rare. One reason for this fact may be the timing of the switch. Not only had the idea of such a move been floated more than a year and a half prior to Shelby's November 9, 1994, decision, but the announcement also came the day after the midterm election.

It is unclear whether the lack of coverage was due to the story's role as a side note to the bigger story of Republican victory in Congress or because party leaders were too preoccupied to voice the outrage associated with most such events. In either case, Shelby timed his switch well. There were the usual objections from state Democrats, but the senator still had a full 4 years remaining on his term. His story seemed effectively lost in the media clamor over the Republican takeover of both chambers, and Shelby's apparent opportunism received little attention. Shelby traded in his position on the Armed Services committee for a spot on Appropriations, retaining his seniority on all his committee assignments. He became the third-ranked Republican on the Banking, Housing, and Urban Affairs committee. He became the chair of that committee at the start of the $108^{\text {th }}$ Congress in 2003 and remained the ranking member as of 2013.

One assumes that any senator holding a seat on the Appropriations committee will make good use of that position, but a concrete example emerged in a news report in 2006 showing at least some of the benefits Shelby derived. According to the account, Shelby was able to channel at least $\$ 50$ million into government contracts for a company called 
COSLA Corp. by 2006. COSLA is a privately owned space and missile defense company headquartered in Hunstville, AL. The funding came after Shelby received $\$ 400,000$ in campaign and committee contributions from the company’s owner, Francisco Collazo, whom Shelby knew 20 years prior to these events. These stories also show that a top official at COSLA during this time was a former aide to the senator (Babcock and Faler 2006). A subsequent news account suggested that other companies whose lobbyists were former Shelby staffers received \$250 million more in federal funds between 2008 and 2010 (Raju and Bresnahan 2010).

This series of events by no means suggests that Shelby's entrance into the Republican Party made him any more likely to engage in unethical behavior. In fact, although accounts of Shelby's dealings with COSLA and other interests imply that an improper relationship may have existed, none directly accuse him of wrongdoing. It is clear, however, that Shelby's time on the Appropriations committee helped him in his pursuit of federal funding for Alabama-based interests. Following his 1994 switch, Shelby took his place on that committee and prepared for his 1998 reelection effort, which he won easily with more than 63 percent of the statewide vote, a decline of less than 2 percent from his 1992 vote share. 
Figure 6. Changes in vote share Richard Shelby experienced after becoming a Republican Alabama

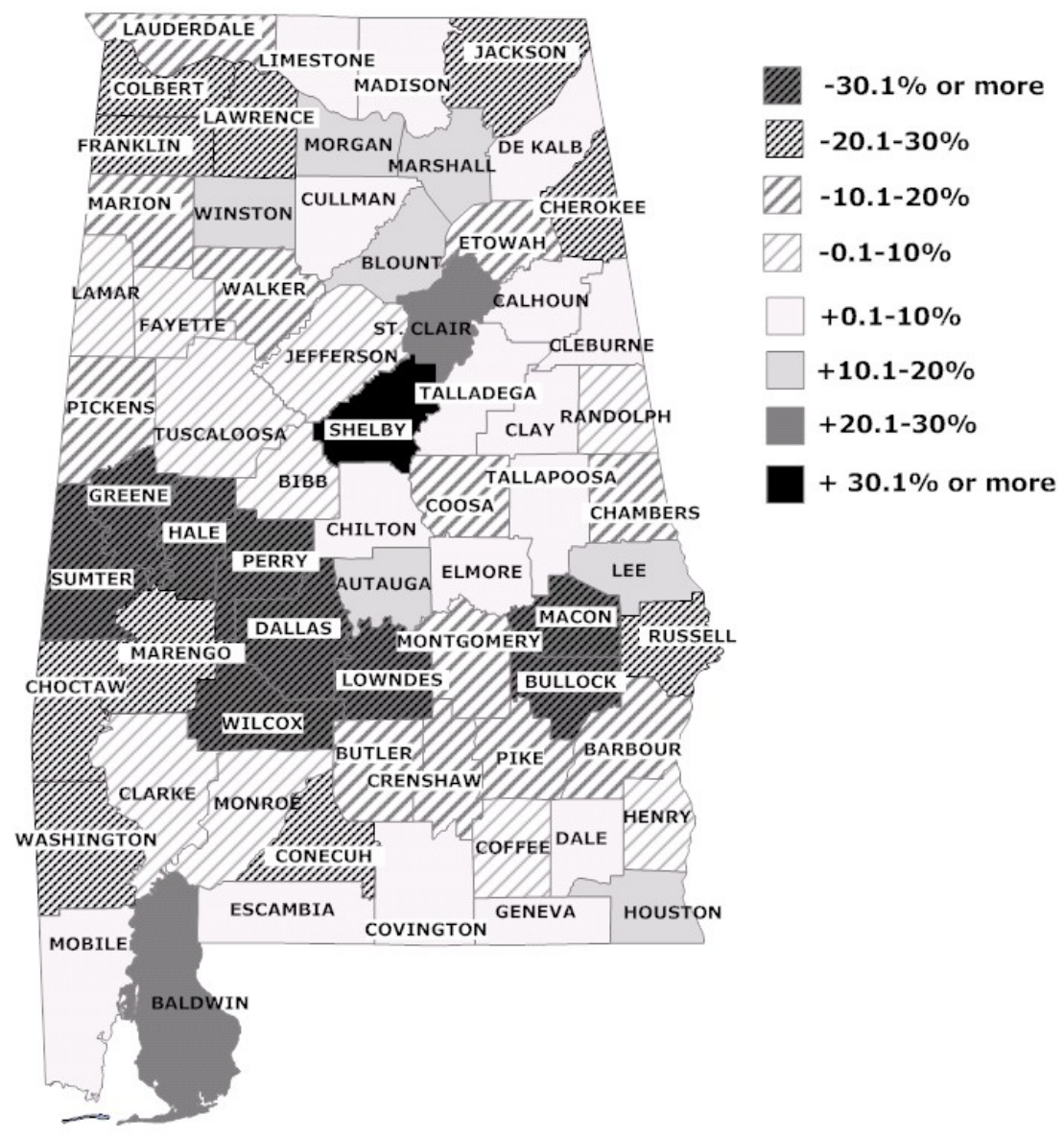

Source: Alabama Secretary of State

Figure 6 shows that although Shelby's statewide vote share remained roughly the same, its geographic distribution changed substantially. The urban-rural divide apparent in Ben Campbell's electoral fortunes is less apparent in Shelby's case. Instead, race may have played a larger role. 
Table 7. Correlations between changes in switchers' vote shares and average partisan vote†

\begin{tabular}{lc} 
Legislator & Pearson Coefficient $\dagger$ \\
\hline Rodney Alexander $\neq$ & $.805^{* *}$ \\
& $.848^{* *}$ \\
Ben Nighthorse Campbell & $.877^{* *}$ \\
Nathan Deal & $.599^{*}$ \\
Richard Shelby & $.958^{* *}$ \\
\hline
\end{tabular}

$\dagger$ Entries are correlation coefficients for the relationship between county-level changes in switchers' vote shares and average county-level Republican presidential vote shares. All members listed switched from Democrat to Republican.

¥The top number uses Alexander’s pre-switch general election vote share to calculate the change variable. The bottom number uses his runoff election vote share.

$* \mathrm{p}<.01$ (two-tailed)

$* * \mathrm{p}<.001$

Table 7 shows that in each of the cases examined here, the shifts in vote share are linked in a predictable way to average partisan vote shares. The table displays the correlation between the change in switchers' vote shares and the average regional Republican presidential vote share. Shelby’s vote shifts are more than 95 percent correlated with average Republican vote share, but regional racial composition appears also to have had an effect. Among those counties in which Shelby lost more than 30 percent of his previous vote share, all were between 58 and 90 percent African American (U.S. Census Bureau 2008).

Shelby’s support from Alabama newspapers also showed signs of changing after he crossed the aisle. The Birmingham News, which tends to endorse Republicans at a higher rate than Democrats, waffled in its support of Shelby as a Democrat. The paper endorsed the conservative Democrat in his 1986 primary race but not in the general election. In his 1992 reelection bid, it endorsed his opponent in the primary but endorsed Shelby in the general election. After Shelby became a Republican, the paper finally gave the senator its complete support in both the 1998 and 2004 contests. 
Table 8. Average regional change in electoral support after changing parties

\begin{tabular}{lc} 
Legislator & Regional Electoral Change $\dagger$ \\
\hline Rodney Alexander $\ddagger$ & $34.1 \%$ \\
Ben Nighthorse Campbell & $20.4 \%$ \\
Nathan Deal & $6.9 \%$ \\
Virgil Goode Jr. & $13.0 \%$ \\
Ralph Hall & $16.7 \%$ \\
Richard Shelby & $17.2 \%$ \\
\hline
\end{tabular}

†Regional electoral change is the averaged absolute value of the difference between pre- and post-switch county-level vote share.

$\ddagger$ For Alexander, the figure is drawn from a comparison between his runoff vote share and his average twoparty vote share in later the following two elections.

The average magnitude of electoral change varies considerably between members, but for each switcher examined here, there was some significant change in the distribution of their electoral support. The percentages in table 8 show the average percentage shift in county-level vote share for a member, comparing his pre- and postswitch elections. Although one switcher, Nathan Deal, experienced only an average of about 7 percent change in the regional distribution of his support, every other member examined experienced double-digit changes in their vote shares. In Rodney Alexander’s case, the difference was more than 34\% on average. By any MC’s standards, one would imagine that kind of shift (or even the magnitudes experienced by Campbell, Goode, Hall, and Shelby) would be considered a major change in the legislator's reelection constituency.

\section{Summary}

In all of the cases examined in depth in this chapter, party defection generated considerable environmental shifts, the significance of which is difficult to dispute. Switchers even in favorable electoral conditions saw large partisan shifts in their geographic constituencies. In short, although switchers retained some of their existing supporters, they regularly saw large swings in their voting bases. Considering the wealth 
of research suggesting that legislators make reelection a central priority of their careers, scholars who underestimate the effects of partisanship on voting blocs do so at their own peril. Not only do party switchers often see the electoral landscape shifting beneath their feet, but many of them could not be examined in this comparative fashion because they either lost a primary contest or chose not to run in anticipation of an electoral defeat.

From the fundraising side of a party switcher's experience, a clear shift is also visible. Those who cross the aisle can expect donors to view them differently and respond accordingly. These changes in funding vary in size, but they are often considerable, exceeding a 10 percent adjustment in the source of funding. In some cases, this trend continues over time, and a switcher to the Republican Party, for example, is unlikely to recover his funding from labor groups and may not even try to do so.

This effect highlights one of the reasons why party-related funding shifts are so potentially meaningful to legislators: They are related to specific pressure groups and their existing relationships with the parties. Groups appear to view a party defection as a signal of future changes in voting behavior. Existing research suggests that this perspective is likely fully justified. Even when prospective switcher Rodney Alexander primed his labor union funders with positive messages about their cause, his ratings as well as his contributions from the offended groups declined. The change in funding Alexander experienced was likely due to changing views of the benefits of continuing to support him. However, the decline is his ratings from labor groups were based on his voting record and, as such, likely indicated a demonstrable behavioral shift away from supporting labor legislatively. Although I chose corporate and labor contributions as a measure of the fundraising portfolios developed by legislators, it is important to note that 
there may be further ways in which precise interests abandoned or increased their support of legislators suddenly sporting a new party label.

Last, a number of little-considered components of a legislator's environment can be shaped by his partisan identity. Endorsements are examples of these factors, and, although I have focused on changes in newspaper endorsements where they occur, it is worth noting that most of the political figures who make meaningful endorsements are themselves lifelong members of a political party. Accordingly, newspaper endorsements appear to be marginally influenced by party affiliation, but endorsements from one’s political peers are, if not exclusively partisan, nearly so. Further, a party switcher should brace for some considerable portion of his staff to resign following the announcement. Considering that staffers are so crucial to a member's pool of information and to communication with constituents, the degree to which (often staunchly) partisan staffers affect the day-to-day operations of a legislative office should not be ignored if one hopes to develop a true picture of a partisan congressional environment. 


\section{"You're either with them or} against them...

I was against them, and they went against me."

- Eugene Atkinson, speaking about the Democratic House leadership under Speaker Tip O’Neill

\section{The Social Environments of Party Switchers}

Although fundraising is a likely source of influence over legislative behavior, the environment in which a legislator functions is much more than just a list of campaign contributors. Raising money certainly takes a lot of time and effort, as does meeting with constituents, but members of Congress also spend a great deal of time interacting with one another. The idea that Congress might be the only work environment in which peer interaction has no effect on one's behavior, beliefs, and performance seems unlikely. MCs report that they spend significant amounts of time not only attending committee proceedings but also holding meetings on legislative matters, discussing pending bills, and meeting with informal caucuses (Davidson, Oleszek, and Lee 2010, 137). This suggests that a major portion of each legislator's day in Washington involves contact with peers. Although it is not a simple task to explain how social interactions influence one's behavior, I start with a simple premise: A sudden, partisan shift in one's social environment is likely to have a significant and partisan impact on legislative behavior.

The trends that are apparent in switchers' electoral and fundraising atmospheres provide evidence of environmental changes outside the beltway, but such shifts may exist in the legislative setting as well. In this chapter, I focus on the social networks in which legislators operate. I find that these social networks are indeed altered following the decision to switch parties and that the observable variations in members' social surroundings are driven both by the behavior of the members themselves and by the reactions of their colleagues to their change in party status. Previous studies have shown that

\footnotetext{
${ }^{7}$ Eugene Atkinson. Telephone interview. March 12, 2010.
} 
members change their voting behavior following a party defection (e.g., McCarty, Poole, and Rosenthal 2001; Nokken 2000). This study goes further, estimating the effects of switching on social networks using a largely symbolic element of legislative behavior: cosponsorship. This dimension of legislative behavior is useful because it represents signaling on the part of the legislator and his colleagues. For the purposes of this analysis, I focus on the partisan makeup of these networks.

Most modern scholars still recognize the wisdom of Woodrow Wilson’s (1885) famous adage that "Congress in its committee-rooms is Congress at work" (79). Accordingly, I seek to present a more complete picture of party switchers' working environments by examining changes to their committee assignments. This analysis, coupled with an examination of trends in switcher cosponsorship behavior, is designed to take indicators of potentially productive working relationships and delineate party affiliation's effect on each.

Bill cosponsorship behavior is relevant to this study for two reasons: It offers evidence of members' attempts at signaling, and it reveals with whom members align themselves and how often. Previous studies have suggested that cosponsoring a bill is an act that can have several motives, among them the goals of winning reelection, gaining sway within the chamber, and making good policy (e.g., Campbell 1982). None of these ends are likely to be reached as a direct result of the action, but all of them can be achieved indirectly through cosponsorship. The act of cosponsoring a bill does not have the immediate impact on a bill's success that a vote might. To cosponsor a bill is to act symbolically, signaling one's support for the proposed legislation to some audience, either inside the legislature or out. Although cosponsorship has the potential to influence legislators to either support or reject a bill, the immediate, measurable effect of the action is limited. Moreover, members regularly “waffle” in their support of legislation, cosponsoring bills they later vote against. The decision to signal support of a 
colleague's sponsored legislation, however, is significant because it demonstrates a member’s desire to signal preferences to a relevant audience.

My primary quantitative measure in this analysis is that of the partisan composition of what I call party switchers' cosponsorship portfolios (i.e., the frequency with which a switcher is involved in cosponsorship activity linked to members of a particular party). I define a member’s cosponsorship portfolio as the sum of the following: (1) instances of the switcher cosponsoring bills sponsored by his colleagues and (2) instances of his colleagues cosponsoring a bill on which he was the sponsor. By assessing the partisan composition of these cosponsorship portfolios, I attempt to approximate the partisan composition of the member's social network.

\section{Previous Study of Cosponsorship}

Scholars have generally accepted the notion that bill cosponsorship plays a role in signaling current and potential supporters, but they differ in their conclusions about which groups are the most likely targets of these signaling efforts. It has been most often suggested that symbolic actions like cosponsorship often make sense for legislators as a means of position taking (e.g., Arnold 1990; Mayhew 1974). MCs with strong support from the NRA and similar groups can, for example, cosponsor a bill protecting or expanding the rights of gun owners. Whether or not that bill passes, those members have sent a message, taking a position that they know will resonate with their supporters if it indeed reaches them. The act of cosponsorship has the appeal of being a low-cost position-taking option, but it is not completely without risk. Many bills are controversial and may represent wedge issues for a member's constituents. If a bill does not represent an issue that divides a member's district supporters, cosponsorship is an easy way to take a position, because doing so presents the possibility of some electoral benefit with almost no cost. 
Other scholars argue that constituent communication is the lesser impetus for signaling behavior. One analysis of the dynamics of cosponsorship behavior finds that the timing of decisions to cosponsor is more consistent with theories of intra-legislative signaling than extra-legislative position taking (Kessler and Krehbiel 1996). The purpose of this chapter is not to determine the specific goals of party switchers' decisions to cosponsor legislation but to determine what changes in cosponsorship trends occur following a switch. If members are unaffected by a change in party affiliation, they should continue signaling roughly the same (either intra- or extra-legislative) audiences before and after switching.

In addition to being a potential outlet for signaling behavior, cosponsorship trends reveal with whom a member chooses to work. I echo James Fowler's (2006) argument that cosponsorship networks are largely comparable to social networks, and I suggest that partisan shifts in these networks can be understood to represent intra-legislative environmental schisms. One might expect members of Congress to support their fellow partisans by cosponsoring their bills more often than those of the opposing party as the result of either partisan coordination or ideological congruence. If legislative peers change their cosponsorship behavior when dealing with the same person under separate party labels, one can reasonably assert that this shift results from the defection. Similarly, a member driven purely by his preferences ought to associate himself with more or less the same group of colleagues regardless of his own party affiliation. He should not need to change his cosponsorship behavior to ingratiate himself to members of his new party if he is driven purely by static policy preferences.

\section{Group Identity and Evaluations of Outsiders}

Social psychological study has yielded considerable wisdom concerning the relationship between members of a group and those they view as outsiders. Publicly, of course, members of Congress regularly criticize the opposing party. They also sometimes turn that criticism toward members of their 
own party, but the latter is a rarer occurrence. If this public frustration with opposing partisans is genuine, it hints at a cognitive organization of the legislative world that is based in large part on party affiliation. Even if this frequent public criticism of members of the opposing party was completely insincere, it could easily offend its targets and weaken inter-party relations in the process.

The vitriol aimed across the aisle is one indication of legislators' impressions of the opposing party as “other,” but a more concrete example is the partisan nature of institutional organization. Legislators contact the leadership of their own party for committee assignments, and it is a branch of that same leadership that is so often successful in encouraging compliance with party vote preferences. In short, there are active, partisan organizations within both chambers of Congress that seek to encourage solidarity and loyalty, sometimes through political horse-trading. Both the mere existence of these organizations and the results of their efforts help to instill an ingroup mentality about fellow partisans and an outgroup view of the opposition.

Based on existing scholarship, one would expect that members of any social group would be more likely to identify positively with those they identify as fellow members (the ingroup) than with those seen as outsiders (the outgroup; e.g., Brewer 1979; Lemyre and Smith 1985; Tajfel 1970). In numerous experimental studies, subjects have shown that they are willing to impose discriminatory labels on outgroup members, even when the social grouping is arbitrary and even controlling for influences such as conflicts of interest and previous animus. This behavior his not anomalous; in fact, evidence suggests that this kind of discrimination is more common in familiar situations (Tajfel and Billic 1974) and within elite social groups (Brewer and Brown 1998). The daily workings of Congress are certainly familiar environs for the average MC, and few would claim that legislators do not see themselves as an elite group. 
Congress thus provides a prime opportunity for testing ingroup and outgroup evaluations. In this case, I use the cosponsorship networks into which MCs place themselves as a measure of social evaluation. Choosing to affiliate oneself with a new group is itself a measure of group assessment, but it could potentially be one based on self-interest rather than a rejection of the perceived values of one's former group. Choosing to work with a group of colleagues, however, is a far better measure of the values that switchers attach to the company of and affiliation with party members.

\section{Theory, Data, and Measurement}

In order to capture potential partisan shifts in cosponsorship networks, I create a simple and intuitive measure of overall network composition. Using the member as the unit of analysis, I create a composite score that represents the percentage of Republican sponsors and cosponsors who either supported the member in question or were supported by him. The final score for each member is calculated by the following equation: $\mathrm{C}=\left(\mathrm{U}_{\text {own }}+\mathrm{U}_{\text {other }}\right) /\left(\mathrm{T}_{\text {own }}+\mathrm{T}_{\text {other }}\right)$. In this equation $\mathrm{U}_{\text {own }}$ is the number of Republican cosponsors for bills sponsored by the member, and $U_{\text {other }}$ is the number of bills the member chose to cosponsor for which the primary sponsor was a Republican. Similarly, $\mathrm{T}_{\mathrm{own}}$ is the total number of cosponsors for bills sponsored by the member, and $\mathrm{T}_{\text {other }}$ is the total number of bills cosponsored by the member. The resulting score is a simple percentage that captures the degree of Republican involvement in each legislator's cosponsorship environment.

For those legislators who have nonzero values for each of the four variables listed above, I am also able to compare the disaggregated scores to determine whether shifts that occur in the aggregate scores are also apparent among their disaggregated components. These components are represented by the equations $\mathrm{R}=\mathrm{U}_{\mathrm{own}} / \mathrm{T}_{\mathrm{own}}$ and $\mathrm{G}=\mathrm{U}_{\text {other }} / \mathrm{T}_{\text {other }}$, where $\mathrm{R}$ is the percentage of Republican cosponsorship received by the member's sponsored legislation, and $\mathrm{G}$ is the percentage of a member's cosponsorship behavior given to Republican-sponsored legislation. I refer to the former measure as 
"support received" and the latter measure as "support given." The value of this type of analysis is that it allows one to determine whether environmental shifts are generated by the member himself or by the other members of the chamber.

A member could choose to cosponsor more of his new party's bills than he has in the past in order to ingratiate himself to his new partisan colleagues or new constituents. Such a change would register as a shift in the partisan composition of support given. Alternatively, a shift in the value for $\mathrm{P}$ (the composite score) might be generated by a trend in which members of the legislator's former party are less willing to cosponsor his legislation, and members of the new party are more willing to do so. This effect would be apparent as a change in support received. If the pre-switch values for $\mathrm{C}\left(\mathrm{C}_{\mathrm{pre}}\right)$ are predictably different than their post-switch counterparts ( $\mathrm{C}_{\text {post }}$; with Republican cosponsorship increasing with a switch the Republican party and vice versa), one observes the predicted partisan shift in the overall network.

H1: For switchers joining the Republican Party, I expect the relationship of $C_{p r e}<C_{p o s t}$ to be evident. For those becoming Democrats, I expect to observe the opposite effect.

Given the dramatic shifts in both electoral and fundraising support that party switchers experience, I further expect that the changes that occur in switchers' cosponsorship networks will be driven largely by a member himself rather than by his legislative colleagues, because his colleagues are unlikely to face similarly shifting district pressures.

H2: For switchers joining the Republican Party, I expect the relationships of $G_{p r e}<G_{\text {post }}$ and $R_{\text {pre }}<$ $R_{\text {post }}$ to be evident. For those becoming Democrats, I expect to observe the opposite effects.

H3: For all switchers, I expect the differences between $G_{p r e}$ and $G_{p o s t}$ to be greater than the difference between $R_{\text {pre }}$ and $R_{\text {post }}$. 
In each case analyzed here I use data obtained from the Library of Congress THOMAS database. Whenever possible, I used data from the member's last full Congress in his party of origin and the first full Congress in his new party. In some cases, however, members either decided to defect before their first Congress was over or left office before completing a full Congress with their new parties. In those cases I use the limited data available, sometimes examining the pre- and post-switch periods within a single Congress.

H4: I expect a significant portion of the party switching population in the House to experience some disruption in their committee memberships, often obtaining positions on the more exclusive committees.

The expectation that committee assignments will fluctuate following a switch is not revolutionary. Committee positions have to at least be reconsidered when a member switches parties because his caucus membership changes. However, anecdotal evidence strongly suggests that, far from being random fluctuations based on seat availability and seniority, switchers' new committee assignments are often the result of bargaining with switchers’ new party leaders (e.g., Choate 2003; Yoshinaka 2005). In many cases potential switchers likely discuss the possibility of switching with the leaders of the opposing caucus, inquiring about the prospects for retaining their committee assignments or acquiring more desirable ones.

Because the anecdotal evidence suggests that switchers bargain for coveted positions on exclusive committees, I expect that they will be relatively more likely to receive those assignments. Leaders hoping to retain these seats during the first post-switch election have two main incentives to provide this kind of help to the newest members of their caucuses. First, leaders are aware of the electoral vulnerability that switching creates for candidates. Leaders are likely aware that, if the member retains his seat in that election, his seat becomes considerably safer thereafter. Second, leaders know that if members receive lesser assignments going into their first election under a new party label, 
they will be susceptible to allegations that they compromised the interests of constituents for political gain or self-preservation.

Findings showing favorable changes in committee assignment would not be definitive proof that committee assignments are governed by partisanship. Anticipated changes on these variables are not evidence that certain committees are innately associated with one party or the other. The proportions of committees occupied by each party are determined almost entirely by the parties’ proportions in the larger chamber. Such a finding would, however, strongly suggest that party leaders and steering committee members are concerned enough about the retaining the seats of party switchers to offer highly sought-after committee positions as compensation for crossing the aisle. Doing so could conceivably cause discord within the party ranks, as other members of the caucus are passed over in favor of a newcomer.

I define the most valuable House committee seats using Groseclose and Stewart's (1998) rankings of committee value in the House. I also use a dichotomous variable based on the parties’ internal measures of the most desirable assignments. Modern party rules suggest that both major parties in the House agree that Rules, Appropriations, Ways and Means, and Energy and Commerce are the top four committees in that chamber (with Democrats also including Financial Services). Rules in the Senate identify Appropriations, Finance, Armed Services, and Foreign Relations as the chamber's most exclusive committees, on which membership is limited to a maximum of one per senator (Schneider 2010; 2012). However, I largely omit Senate committee assignments from this analysis because of the extremely high rate at which senators serve on one of the most exclusive committees. ${ }^{8}$

\footnotetext{
${ }^{8}$ The parties limit the membership of four Senate committees (Appropriations, Armed Services, Finance, and Foreign Relations) on the basis of the rate at which membership is requested. In the three Congresses that I analyze for House party switchers (the 103rd, 105th, and 108th), senators held seats on one of these four committees at a rate of 89 percent. Senate party switchers held seats on these committees at a rate of 80 percent both before and after defecting.
} 
In addition to the binary measure for the presence of a top-four committee in a member's assignments, I also take advantage of the committee ranking system designed by Groseclose and Stewart (1998). Tracking the highest ranking committee to which a member belongs, I determine the average expected shift in committee value. Specfically, I examine how, if at all, a member's top assignment improves as a result of switching parties. I take this approach rather than one that relies on the average committee ranking because that approach would devalue positions on powerful committees when members also sit on low-ranking committee.

An example of the potentially distorting effect of this approach would be a member of the Ways and Means Committee — the top-ranking committee under this measure — who is also a member of the Small Business Committee. Such a member would produce an average committee ranking based on committees ranked 1 and 23 respectively. The resulting score of 14 would put that member on par with a member sitting only on the Banking Committee. The trade-off with the top-ranked committee measure is that a member serving on two relatively highly ranked committees would not be credited with membership on his second-ranked committee. This flaw, however, introduces far less error than the alternative in creating as accurate a measure of true committee power as possible.

H5: I predict that those members who maintain their committee assignments will experience violations of the seniority norm at a much higher rate than an average member of the chamber.

This was the finding Yoshinaka (2005) produced in his analysis of this subject, but I extend the analysis both in terms of years examined and across chambers. To do so I use congressional committee assignment data (Nelson N.d.; Stewart and Woon 2011). As is true for H4, the reasoning behind this hypothesis is related primarily to the expectation that party leaders are intensely concerned with the sizes of their caucuses. In general terms, this is not a controversial claim, but by using individual party switchers as subjects, this analysis provides a tough test for the intensity with which leaders pursue even 
small changes in caucus size. In Jim Jeffords's case, a small change in the size of the caucus has meant a shift in the parties' majority-minority status. In Arlen Specter's, it meant the Democratic caucus swelled to a 60-vote majority. Those two instances are the only examples of single party switchers prompting major, chamber-wide shifts.

Much more often, switchers slightly increase the size of a majority (or, less often, a minority) caucus without having any pivotal impact on the parties' overall standings. This being the case, the relatively inconsequential shift in party composition ought to garner little attention from leaders confident that members will be guided to behave in accordance with their ideologies. Conversely, leaders preoccupied with even marginal increases in party power might be compelled to expend valuable committee positions in order to achieve and maintain those gains.

Committee assignments and members' rankings within their committees are, of course, governed in large part by seniority. Violations of seniority norms are often driven by party leaders and are relatively rare. Incoming committee members generally start at the lowest rank and progress up the seniority ladder as departures from the committee leave positions open at the higher ranks. I expect to find, consistent with previous literature, that violations of the seniority norm are far more common among party switchers than other members of the chamber. This expectation stems in part from the

probability that party leaders use their influence in the committee assignment process to offer benefits to prospective switchers. However, it is also based on the idea that potential switchers know their seats are worth enough to leaders that they would be willing to sacrifice top committee assignments to add one member to their caucus.

\section{Results}

In the majority of cases analyzed here, H1 holds. Party switchers’ composite cosponsorship scores demonstrate a clear trend. Switchers engage in different social cosponsorship networks before 
and after they cross the aisle. In short, members' cosponsorship networks are more Republican when the member himself is a Republican and less so when he is a Democrat.

Table 9. Shifts in composite cosponsorship scores for party switchers

\begin{tabular}{lc} 
Member & $\begin{array}{c}\text { Change in } \\
\text { Expected Direction }\end{array}$ \\
\hline Alexander, Rodney & $28.9 \%$ \\
\hline Atkinson, Eugene & $13.3 \%$ \\
Campbell, Ben & $27.9 \%$ \\
Deal, Nathan & $22.2 \%$ \\
Forbes, Michael & $26.8 \%$ \\
Goode, Virgil† & $11.0 \%$ \\
Gramm, Phil & $-8.6 \%$ \\
Grant, Bill & $19.4 \%$ \\
Griffith, Parker & $57.3 \%$ \\
\hline Hall, Ralph & $13.7 \%$ \\
\hline Hayes, James & $31.3 \%$ \\
Ireland, Andy & $9.9 \%$ \\
\hline Jeffords, James* & $13.8 \%$ \\
Laughlin, Greg & $63.5 \%$ \\
Lieberman, Joseph & $0.7 \%$ \\
\hline Martínez, Matthew & $1.9 \%$ \\
Parker, Mike & $40.9 \%$ \\
Peyser, Peter & $-10.5 \%$ \\
Robinson, Tommy & $19.5 \%$ \\
\hline Shelby, Richard & $38.4 \%$ \\
\hline Specter, Arlen & $21.4 \%$ \\
\hline Stump, Bob & $23.8 \%$ \\
\hline Tauzin, Billy & $5.1 \%$ \\
\hline Watkins, Wesley & $55.1 \%$ \\
\hline AVG & $\mathbf{2 1 . 9 \%}$ \\
ST Dev. & $\mathbf{1 9 . 2 \%}$ \\
\hline
\end{tabular}

†The data for Virgil Goode come from his last full Congress as a Democrat and his first full Congress as a Republican. Years in which he was an independent are omitted.

*For both Jeffords and Lieberman (who became independents), I set the expected change to a movement away from their former party, although only Jeffords changed party caucuses.

Although the degree of change in switchers' social networks varies by case, there are only two cases in which H1 is not confirmed: those of Phil Gramm (TX) and Peter Peyser (NY). For the most part, $\mathrm{H} 2$ is also supported. Both support given and support received move in the expected direction in 
the majority of cases. It is only in the cases of Matthew Martínez, Peter Peyser, and Phil Gramm that the measure for support given does not move in the expected direction. 
Figure 7. Composite Cosponsorship Scores for Party Switchers (percent Republican), 1980-2013*

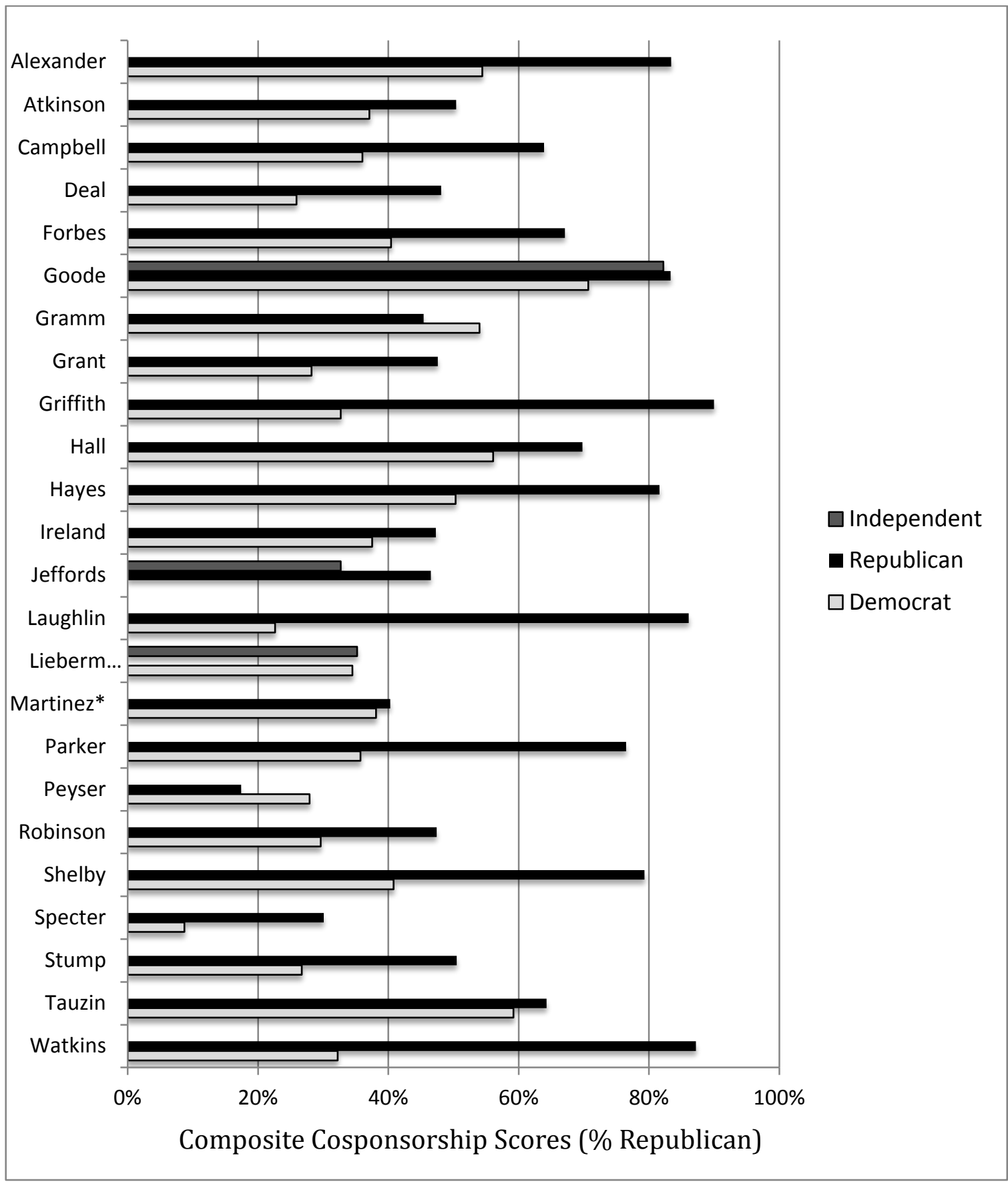

* As independents, Goode and Shelby switched caucuses. Lieberman changed status but continued to caucus with Senate Democrats.

Source: THOMAS legislative records database.

Joe Lieberman also experienced a drop in Republican support after leaving the Democratic Party to become an independent Democrat, but the expectation in his case is somewhat less clear as he 
remained in the Democratic caucus. In the other 19 cases examined here, the expected effect is observed. On the support received measure, only Billy Tauzin, James Hayes, and Peter Peyser experienced something other than the expected shift. The other 16 cases for which data were available produced the expected effect. H3, however, is not supported. 
Figure 8. Support Given by Party Switchers to Republican-Sponsored Bills, 1980-2010

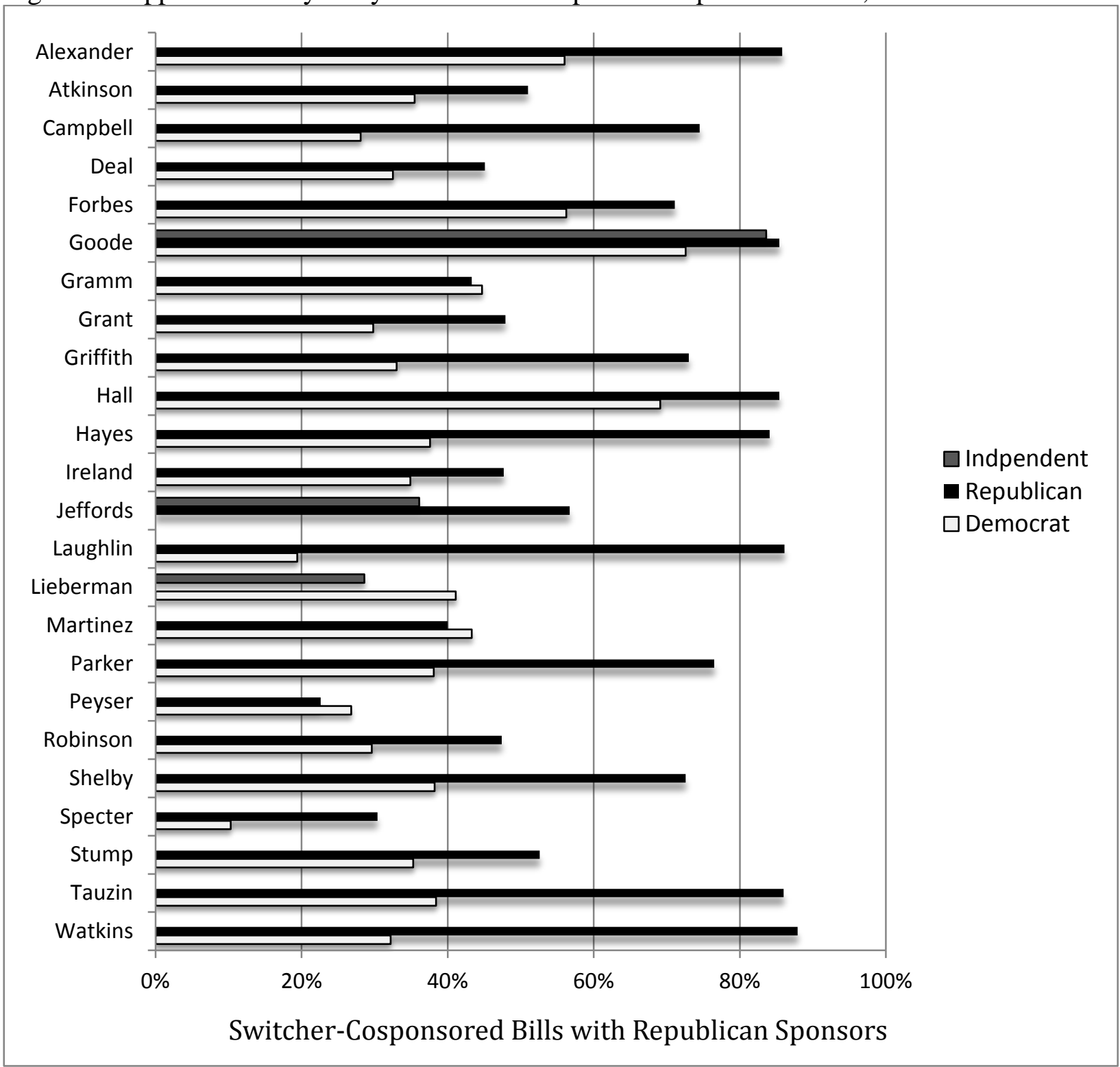

Source: THOMAS legislative records database. 
Table 10. Comparison of Changes in Support Given and Support Received*

\begin{tabular}{lccc} 
Member & $\begin{array}{c}\Delta \text { Support } \\
\text { Given }\end{array}$ & $\begin{array}{c}\Delta \text { Support } \\
\text { Received }\end{array}$ & $\begin{array}{c}\text { Predicted } \\
\text { Relationship? }\end{array}$ \\
\hline Alexander & $29.8 \%$ & $22.3 \%$ & Yes \\
Atkinson & $15.6 \%$ & $0.3 \%$ & Yes \\
Campbell & $46.3 \%$ & $1.6 \%$ & Yes \\
Deal & $12.6 \%$ & $88.9 \%$ & No \\
Forbes & $14.9 \%$ & $45.0 \%$ & No \\
Goode & $12.8 \%$ & $57.5 \%$ & No \\
Gramm & $-1.4 \%$ & $18.3 \%$ & No \\
Grant & $18.1 \%$ & $22.9 \%$ & No \\
Hall & $16.3 \%$ & $28.3 \%$ & No \\
Hayes & $46.5 \%$ & $-2.0 \%$ & Yes \\
Ireland & $12.8 \%$ & $0.9 \%$ & Yes \\
Peyser & $-4.2 \%$ & $-13.8 \%$ & Yes \\
Shelby & $34.4 \%$ & $36.9 \%$ & No \\
Specter & & & - \\
Stump & $17.3 \%$ & $23.6 \%$ & No \\
Tauzin & $47.6 \%$ & $-4.3 \%$ & Yes \\
Watkins & $55.6 \%$ & $53.6 \%$ & Yes \\
\hline
\end{tabular}

* Parker Griffith is not listed due to his complete lack of cosponsorship support as a Democrat.

No single dimension of the composite score overwhelms the other. Figures 8 and 9 show that (with few exceptions) partisan cosponsorship shifts occur in the expected direction in terms of both support given and support received. In the cases of both the measure for support given and the one for support received, the average change was about a 23 percent swing in the expected direction. This suggests that members' social environments shift as the result of their own actions as well as the reaction of the caucuses to their new party status. 
Figure 9. Support Received by Party Switchers from Republicans, 1980-2013

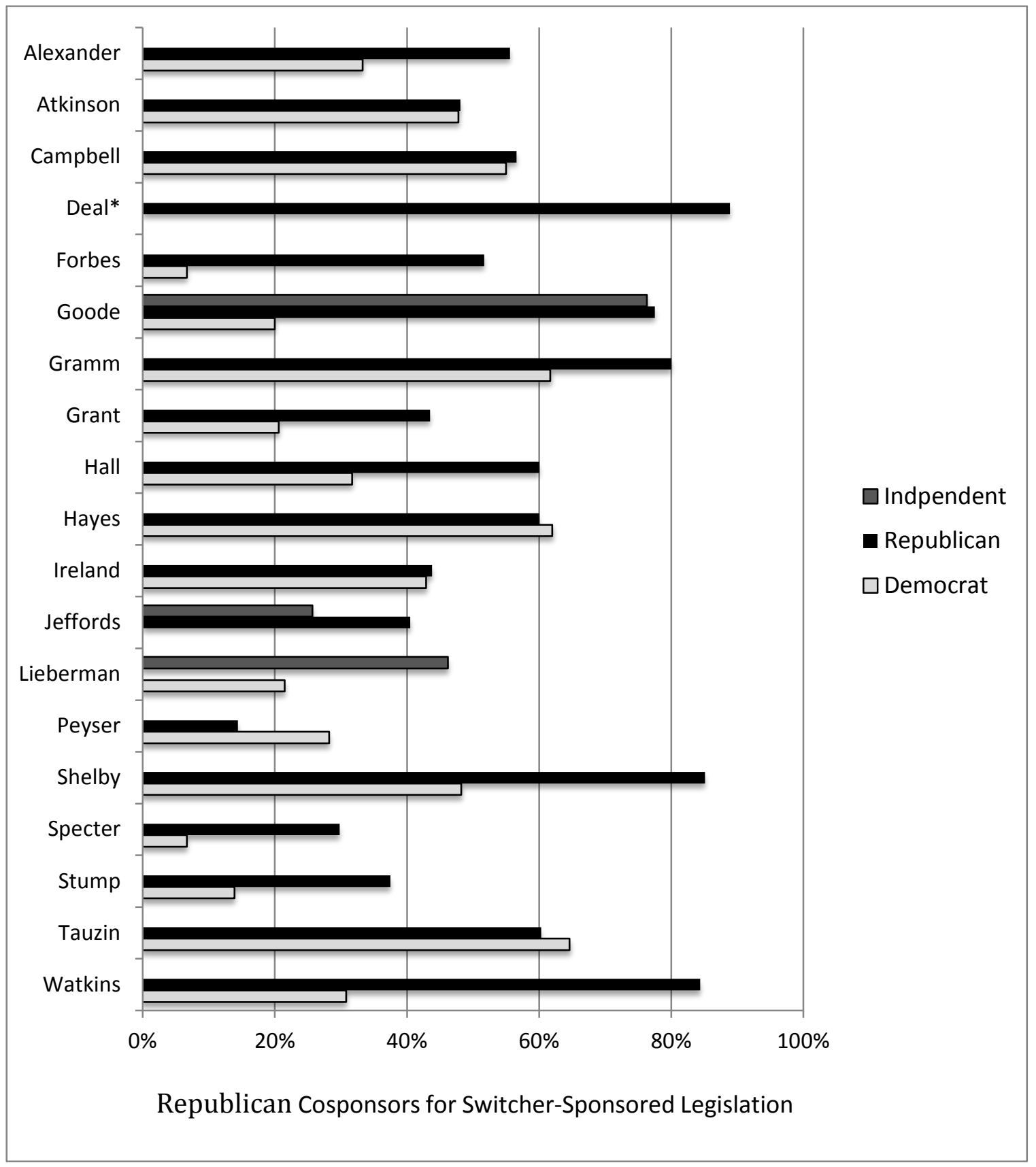

*Nathan Deal sponsored 4 bills as a Democrat in the 103rd Congress. Those bills received 41 cosponsorships, but none were from Republicans. Parker Griffith is omitted from this chart because none of the bills he sponsored as a Democrat received any cosponsors.

Source: THOMAS legislative records database. 


\section{Switchers to the Republican Party}

The majority of cases discussed here are examples of Democrats who became Republicans. The average Democrat switching to the Republican Party in this sample experienced a more than 23 percent increase in Republican cosponsorship activity. This is a moderately larger difference than that of the average switcher to the Democratic Party (about a 12.6 percent drop in Republican cosponsorship).

One criticism of my method might be to suggest that these network shifts are short-term phenomena that represent immediate reactions to the news of a switch and not long-term effects on the member's social network. One test of this critique is the case of Oklahoma Congressman Wesley Watkins. Watkins was first elected as a Democrat in Oklahoma’s 3rd district in 1976 and served seven terms under that party label. His migration away from the Democratic and toward the Republican Party was lengthy. Watkins did not seek an eighth term in 1990, instead choosing to run for governor of

Oklahoma as a Democrat. He lost that race and ran for governor again in 1994, this time as an independent. He lost again, and in 1996 he decided to try to take back his House seat as a Republican. This time he was successful, winning the race with a clear majority (Hoberock 1996). The cosponsorship data available for Watkins' tenure as a Democrat therefore ends in 1990, and the data concerning his cosponsorship activity as a Republican begins in 1997, about 3 years after leaving the Democratic Party and a number of months after filing to run for his old seat as a Republican. Despite the length of his transition to his new party, the difference in his cosponsorship activity between 1990 and 1997 is dramatic. Only one other party switcher (Greg Laughlin of Texas) had a network shift that eclipsed Watkins’s more than 55 percent swing.

\section{Switchers to the Democratic Party}

Among the small number of congressional Republicans who have become Democrats in the past several decades, the finding for $\mathrm{H} 1$ is moderately weaker on average than for their Republican 
counterparts. It is worth noting that of the three switchers to the Democratic Party analyzed here, one (Peter Peyser) had an increase of more than 10 percent in Republican cosponsorship following his switch, but the other two (Arlen Specter and Michael Forbes) both saw the expected declines in Republican cosponsorship (more than 21 percent in both cases).

Peter Peyser

Peter Peyser’s case is an interesting one, and in spite of the quantitative finding that his social network defies the expectations of this analysis, his story reaffirms the importance of party. Peyser was elected as a Republican in 1970 to represent New York’s 25th district but was later redistricted into the 23rd. When I spoke with Peyser, he attributed much of the credit for his initial election to then-New York governor Nelson Rockefeller. Rockefeller was an ally in both name and deed, contributing financially to Peyser’s campaign as well as supporting him publicly (Lynn 1975). Peyser’s support among top Republican leaders waned over time, however. He attributes this phenomenon to his tendency to vote with Democrats on key legislative issues.

Another contributing factor may have been a disagreement that Peyser had with Republican leaders over his 1976 Senate bid. When Peyser decided to seek the Republican nomination for the U.S. Senate seat held by Conservative Party member James Buckley, he failed to receive key leaders’ endorsements. He lost the Republican primary to Buckley, who went on to lose in the general election, and Peyser decided, “I just no longer had a place in the Republican Party.” In fact, media accounts suggest that Peyser had begun to lose the support of Republican leaders as early as March of 1975, three months into the Congress that I use to establish his pre-switch social network data. By the time he actually switched parties, Peyser suggests, "many political people were glad I was gone from the party.”

Only a week after meeting with key figures in the New York Republican Party and publicly announcing his intention to run for the Senate seat, political advisor to Nelson Rockefeller and New 
York Republican national committee member George Hinson wrote a letter to Peyser, sending copies to Republican state and congressional leaders. In it, Hinson attacked Peyser's integrity and suggested that he was not fit to hold public office. According to Hinson, Peyser erroneously claimed that Rockefeller aides had not urged him to stay out of the race. Peyser responded that although Hinson had urged him not to run, it was not clear that the message came from anyone higher up than himself. The quarrel made it into the New York Times in an article that suggested Republican leaders felt that Peyser had endangered not only his candidacy for the Senate but his House seat as well (Lynn 1975).

Making himself a candidate for Senate in 1976, Peyser vacated his House seat but lost the Republican primary and retook the House seat as a Democrat in 1978. He served in that seat until 1982, when, under a process heavily influenced by New York Republicans, his district was eliminated. The redistricting process put him into competition with incumbent Republican Ben Gilman, and he lost the race. Peyser describes the redistricting move as "revenge.” As his actions prompted sharp rebuke from key Republican figures, they also drew strong praise from key Democrats. When I asked him about any help or opposition he might have received from party leaders, he pointed to then-Speaker of the House Tip O’Neill as a key source of support. He added:

Members of Congress and different groups (that were strictly Democratic operations) were very quick to endorse me, and loads of key people in the Democratic Party who came out to endorse me. Senator [D. Patrick] Moynihan (D-NY) really went out of his way in supporting me, coming with me and so forth.

Peyser’s story of intense scrutiny from members of his former party and warm acceptance from his new party is by no means unique, and it highlights the strong emotional and political responses that party switching often evokes among top party figures. The influence of these leaders is downplayed by scholars advancing theories of legislative organization based on preference as distinct from party, but party switchers like Peter Peyser suggest that one’s standing with top party officials can have profound influence, both positive and negative, on one's career. By Peyser's account, the actions of state 
Republicans may have ended his political career or at least contributed to its conclusion. If one ignores the 94th Congress (in which Peyser chose to run for the Senate) and instead compares his first Congress as a Democrat with the 93rd, the expected result is indeed observed: a decline in composite Republican cosponsorship of more than 14 percent.

\section{Phil Gramm}

No one in the $97^{\text {th }}$ Congress would have classified Phil Gramm of Texas as a friend to the Democratic House leadership. In fact, Gramm was a vocal critic of Speaker Tip O’Neill, commenting that his district was more supportive of President Reagan's budget than that of House Democrats (Miller 1981). Perhaps public criticism of party leaders could have been overlooked by the average member of the Democratic caucus, but his role in passing budget cuts called for by the Reagan White House caught the attention of many. When Gramm entered Congress as a Democrat in 1979 he was awarded a coveted spot on one of the better committees: Interstate and Foreign Commerce (now known as Energy and Commerce). When the 97th Congress started in 1981, he was placed on another influential committee: Budget. Within a month of being placed on the Budget Committee, he was siding with the Republican president over the Democratic leadership. Less than 2 months later, he was actively involved in closed-door negotiations with budget director David Stockman and Republican Representative Jack Kemp, also a member of the Budget Committee. Gramm then led a group of socalled "boll weevils" in their support of two aspects of Reagan’s budget proposal: (1) limiting overall spending and (2) refusing to cut the defense budget (Evans and Novak 1981).

Partisan dissatisfaction with Gramm grew as Democratic members of the Budget committee began to suspect (and suggested publicly) that he had been actively communicating the substance of secret meetings to the Republican opposition (Romano 1983). At least one study suggests that it was this violation of behavioral norms, and not the violation of party discipline, that accounted for Gramm 
being removed from his position on the committee in 1983 (Baker 1985). This line of argument seems to ignore the fact that the norm being violated in this case is one of partisan unity: that the content of secret partisan meetings is not to be shared with the other side.

This type of team mentality is understandably common in an institution formally organized by caucus membership and was alluded to several times in the interviews I conducted. That is not to say that ideology played no role in Gramm's case, only that strong partisan concerns and influence were clearly present. A liberal democrat would never have been in a position to upset his fellow partisans in quite this way. Gramm's behavior must have alienated some Democrats, just as it invited the support of many Republicans. This is not evident in the data I present, but, just as with Peyser, if one goes back another session (before this public falling out with his party), the result changes. A comparison of the 97th Congress to the 98th shows that after becoming a Republican, Gramm experienced a decline of more than 8 percent in his interaction with Republicans. If one throws out the 97th Congress and instead uses the 96th as the point of comparison, the expected directional effect is apparent (an increase of more than 7 percent in Republican cospsonsorship). It may also be worth mentioning that, despite the public humiliation Democratic leaders experienced as the result of Gramm's actions, the direction of his composite score is driven by his own activity. On the measure of support received from his fellow members, his scores move in the predicted direction.

One could argue whether Gramm’s apparent popularity within the caucus during the 97th Congress is the independent result of his lack of party discipline or his conservative ideology. Were Republicans more supportive because Gramm was breaking with his party and supporting the goals of their own party leaders, or were they more inclined to work with him because his views more closely matched their own? Phrased this way, it seems likely that both are true. I would argue that this case illustrates that partisan culture and ideology are inextricably linked. Prominent Democrats, whether 
those on the Steering and Policy committee or those in more visible leadership roles, would clearly have preferred that no Democrat (regardless of ideology) vote against them. Still, the committee took punitive action against Gramm in large part because he was seen as cooperating with the enemy. There can be little question that working with other conservative Democrats (or "boll weevils") would not have drawn the same level of disapproval from his fellow partisans.

Another possible explanation for Gramm's punishment might be the fact that he violated a pledge he made directly to the Democratic Steering and Policy committee. Before being placed on the Budget committee, he promised that he would "work diligently to assure that Democrats in the House are presented budget resolutions they can enthusiastically support on the floor and in their districts” (Baker 1985, 319). It may have been the violation of this pledge that so angered Democrats, but why make this kind of promise in the first place? The apparent answer is that Democrats on the Steering and Policy committee were uneasy enough about Gramm’s ideological background that they needed some assurance that he would toe the party line in his role on a key committee. After violating the promise to work with and not against the party on budget issues, he was jettisoned from the committee before regaining his position on it as a Republican.

\section{Switchers to Independent Status}

I examine two cases of switchers moving from their party of origin to independent status: James Jeffords (VT) and Joseph Lieberman (CT). In Senator Jeffords’s case, he switched caucuses, famously shifting the balance of power in the Senate in favor of the Democrats. Despite being the cause of a wholesale shift in the partisan balance of power in the Senate, Jeffords experienced only a relatively small shift in his overall cosponsorship network. He experienced a decline of about 13.8 percent in his 
composite Republican cosponsorship network, a modest figure compared to the 27.9 percent and 38.5 percent declines experienced by fellow Senators Ben Campbell and Richard Shelby, respectively. ${ }^{9}$ Unlike Jeffords, Sen. Lieberman did not switch party caucuses, only party labels. Having lost his 2006 Democratic primary, Lieberman decided to run as an Independent Democrat in that year's general election. He won the contest, and in the 110th Congress his cosponsorship network was only 0.7 percent more Republican than it had been during the 108th. ${ }^{10}$ The virtual absence of change between Lieberman's social network before and after his switch may be the result of the distinctive nature of his decision. Not only did he make the decision to switch parties out of obvious political necessity (i.e., his desire to retain his office) rather than policy disagreement or personal malice, but he also remained in the Democratic caucus, even retaining the label: Independent Democrat.

There is little doubt that some liberal Democrats resented his refusal to step down in favor of the more liberal primary winner Ned Lamont, but Senate Democrats may not have noticed much difference in a colleague whose caucus membership did not change and whose voting behavior appeared to stay consistent. A glance at Lieberman's interest group ratings shows that his average ADA score for 20052006 was 77.5 of 100 . As an Independent Democrat in 2007-2008, his average score was exactly the same (Americans for Democratic Action 2011). Similarly, his average ACU score for 2005-2006 was 12.5 of 100, and his average score between 2007-2008 was an 8, showing that the ACU considered him to be 4.5 percent more liberal after leaving the Democratic Party (American Conservative Union 2011). The problems with using these scores as reliable measures of voting behavior are well documented (e.g., Snyder 1992), but it is worth noting that at least in the opinions of two interest groups, Lieberman was essentially the same senator as an independent, or perhaps slightly more liberal.

\section{Party Switching and House Committee Assignments}

\footnotetext{
${ }^{9}$ Both Campbell and Shelby switched from the Democratic to the Republican Party.

${ }^{10}$ I use the 108th Congress as Lieberman's last full Congress as a Democrat, because, at least for a portion of the 109th, he has already made the nominal change to Independent Democrat.
} 
Examining the committee assignments of House party switchers, my results show that for $\mathrm{H} 4$ the strongest support for the predicted relationship began after the Republican Revolution. Generally, House members who switched parties after this era began either received or retained seats on the top four committees. Beginning in the 104th Congress, the lone House party switcher who did not sit on one of those top four committees after defecting was Matthew Martínez. Rep. Martínez’s case was distinctive because he had already lost the Democratic primary when he became a Republican. As a result, the Republican primary had passed when the switch occurred, and Martínez had already decided not to wage a write-in campaign, effectively choosing to retire at the end of the session when committee memberships were assigned. With Martínez lacking any immediate chance of returning to Congress, party leaders could not have thought that there was any advantage to plying him with a valuable committee seat. 
Table 11. House Committee Assignment Shifts for Party Switchers, 1975-1991

\begin{tabular}{|c|c|c|c|c|c|c|c|c|c|c|c|c|}
\hline Member & State & Congress & Direction & $\begin{array}{l}\text { Committee(s) } \\
\text { Assigned } \\
\text { Immediately } \\
\text { Prior to } \\
\text { Switch }\end{array}$ & $\begin{array}{l}\text { Committee(s) } \\
\text { Assigned } \\
\text { Immediately } \\
\text { Following } \\
\text { Switch }\end{array}$ & $\begin{array}{l}\text { Top } 4 \\
\text { pre- } \\
\text { switch? }\end{array}$ & $\begin{array}{l}\text { Top } 4 \\
\text { post- } \\
\text { Switch? }\end{array}$ & $\begin{array}{l}\text { Best } \\
\text { Rank } \\
\text { Pre } \\
\end{array}$ & $\begin{array}{l}\text { Best } \\
\text { Rank } \\
\text { Post } \\
\end{array}$ & $\begin{array}{l}\Delta \text { in } \\
\text { highest } \\
\text { rank } \\
\text { (expected } \\
\text { direction) }\end{array}$ & $\begin{array}{l}\text { Committee } \\
\text { Change? }\end{array}$ & $\begin{array}{l}\text { Reward } \\
\text { Violating } \\
\text { Seniority } \\
\text { Norm? }\end{array}$ \\
\hline $\begin{array}{l}\text { Jarmon, } \\
\text { John }\end{array}$ & OK & 94th & $\mathrm{D}$ to $\mathrm{R}$ & $\begin{array}{l}\text { Interstate and } \\
\text { Foreign } \\
\text { Commerce }\end{array}$ & $\begin{array}{l}\text { Science and } \\
\text { Technology }\end{array}$ & Yes & No & 4 & 17 & -13 & Yes & Yes \\
\hline $\begin{array}{l}\text { Peyser, } \\
\text { Peter }\end{array}$ & NY & 96th & R to $\mathrm{D}$ & $\begin{array}{l}\text { Agriculture; } \\
\text { Education and } \\
\text { Labor }\end{array}$ & $\begin{array}{l}\text { Education and } \\
\text { Labor; House } \\
\text { Administration }\end{array}$ & No & No & 11 & 8 & 3 & Yes & No \\
\hline $\begin{array}{l}\text { Atkinson, } \\
\text { Eugene }\end{array}$ & PA & 97th & D to $\mathrm{R}$ & $\begin{array}{l}\text { Government } \\
\text { Operations; } \\
\text { Public Works } \\
\text { and } \\
\text { Transportation }\end{array}$ & $\begin{array}{l}\text { Government } \\
\text { Operations; } \\
\text { Public Works } \\
\text { and } \\
\text { Transportation }\end{array}$ & No & No & 16 & 16 & 0 & No & No \\
\hline Gramm, Phil & $\mathrm{TX}$ & 98th & $\mathrm{D}$ to $\mathrm{R}$ & None & $\begin{array}{l}\text { Budget; } \\
\text { Veterans' } \\
\text { Affairs }\end{array}$ & No & No & 24 & 7 & 17 & Yes & Yes \\
\hline $\begin{array}{l}\text { Ireland, } \\
\text { Andy }\end{array}$ & FL & $\begin{array}{l}\text { 98th and } \\
\text { 99th }\end{array}$ & $\mathrm{D}$ to $\mathrm{R}$ & $\begin{array}{l}\text { Foreign } \\
\text { Affairs; Small } \\
\text { Business }\end{array}$ & $\begin{array}{l}\text { Small } \\
\text { Business }\end{array}$ & No & No & 6 & 23 & -17 & Yes & $\begin{array}{l}\text { No-98th; } \\
\text { Yes-99th }\end{array}$ \\
\hline Stump, Bob & $\mathrm{AZ}$ & 98th & $\mathrm{D}$ to $\mathrm{R}$ & $\begin{array}{l}\text { Armed } \\
\text { Services; } \\
\text { Veterans' } \\
\text { Affairs }\end{array}$ & $\begin{array}{l}\text { Armed } \\
\text { Services }\end{array}$ & No & No & 5 & 5 & 0 & Yes & Yes \\
\hline Grant, Bill & FL & $101 \mathrm{st}$ & $\mathrm{D}$ to $\mathrm{R}$ & $\begin{array}{l}\text { Government } \\
\text { Operations; } \\
\text { Public Works } \\
\text { and } \\
\text { Transportation }\end{array}$ & $\begin{array}{l}\text { Agriculture; } \\
\text { Public Works } \\
\text { and } \\
\text { Transportation }\end{array}$ & No & No & 16 & 11 & 5 & Yes & No \\
\hline \multirow[t]{3}{*}{$\begin{array}{l}\text { Robinson, } \\
\text { Tommy }\end{array}$} & AR & $101 \mathrm{st}$ & $\mathrm{D}$ to $\mathrm{R}$ & $\begin{array}{l}\text { Armed } \\
\text { Services; } \\
\text { Veterans' } \\
\text { Affairs }\end{array}$ & $\begin{array}{l}\text { Education and } \\
\text { Labor; Post } \\
\text { Office and } \\
\text { Civil Service }\end{array}$ & No & No & 5 & 18 & -13 & Yes & No \\
\hline & & & & & & & Mean & 10.9 & 13.1 & -2.3 & & \\
\hline & & & & & & & $\begin{array}{l}\text { Std. } \\
\text { Dev }\end{array}$ & 7.2 & 6.3 & 11.4 & & \\
\hline
\end{tabular}

Sources: Nelson (n.d.), Stewart and Woon (2011), and Yoshinaka (200 
Table 12. House Committee Assignment Shifts for Party Switchers, 1995-2011

\begin{tabular}{|c|c|c|c|c|c|c|c|c|c|c|c|c|}
\hline Member & State & Congress & Direction & $\begin{array}{l}\text { Committee(s) } \\
\text { Assigned } \\
\text { Immediately } \\
\text { Prior to } \\
\text { Switch } \\
\end{array}$ & $\begin{array}{l}\text { Committee(s) } \\
\text { Assigned } \\
\text { Immediately } \\
\text { Following } \\
\text { Switch } \\
\end{array}$ & $\begin{array}{l}\text { Top } 4 \\
\text { pre- } \\
\text { switch? }\end{array}$ & $\begin{array}{l}\text { Top } 4 \\
\text { post- } \\
\text { switch? }\end{array}$ & $\begin{array}{l}\text { Best } \\
\text { Rank } \\
\text { Pre } \\
\end{array}$ & $\begin{array}{l}\text { Best } \\
\text { Rank } \\
\text { Post } \\
\end{array}$ & $\begin{array}{l}\Delta \text { in } \\
\text { highest } \\
\text { rank } \\
\text { (expected } \\
\text { direction) }\end{array}$ & $\begin{array}{l}\text { Committee } \\
\text { Change? }\end{array}$ & $\begin{array}{l}\text { Reward } \\
\text { Violating } \\
\text { Seniority } \\
\text { Norm? } \\
\end{array}$ \\
\hline Deal, Nathan & GA & 104th & $\mathrm{D}$ to $\mathrm{R}$ & $\begin{array}{l}\text { Resources; } \\
\text { Transportation, } \\
\text { and } \\
\text { Infrastructure }\end{array}$ & Commerce & No & Yes & 10 & 4 & 6 & Yes & Yes \\
\hline $\begin{array}{l}\text { Hayes, } \\
\text { Jimmy }\end{array}$ & LA & 104th & $\mathrm{D}$ to $\mathrm{R}$ & $\begin{array}{l}\text { Science; } \\
\text { Transportation } \\
\text { and } \\
\text { Infrastructure }\end{array}$ & $\begin{array}{l}\text { Ways and } \\
\text { Means }\end{array}$ & No & Yes & 16 & 1 & 15 & Yes & Yes \\
\hline $\begin{array}{l}\text { Laughlin, } \\
\text { Greg }\end{array}$ & $\mathrm{TX}$ & 104th & $\mathrm{D}$ to $\mathrm{R}$ & $\begin{array}{l}\text { Transportation } \\
\text { and } \\
\text { Infrastructure }\end{array}$ & $\begin{array}{l}\text { Ways and } \\
\text { Means }\end{array}$ & No & Yes & 16 & 1 & 15 & Yes & Yes \\
\hline Parker, Mike & MS & 104th & $\mathrm{D}$ to $\mathrm{R}$ & $\begin{array}{l}\text { Budget; } \\
\text { Transportation } \\
\text { and } \\
\text { Infrastructure }\end{array}$ & Appropriations & No & Yes & 7 & 2 & 5 & Yes & Yes \\
\hline Tauzin, Billy & LA & 104th & $\mathrm{D}$ to $\mathrm{R}$ & $\begin{array}{l}\text { Commerce; } \\
\text { Resources }\end{array}$ & $\begin{array}{l}\text { Commerce; } \\
\text { Resources }\end{array}$ & Yes & Yes & 4 & 4 & 0 & No & Yes \\
\hline Watkins, Wes & $\mathrm{OK}$ & 105th & $\mathrm{D}$ to $\mathrm{R}$ & Appropriations & $\begin{array}{l}\text { Ways and } \\
\text { Means }\end{array}$ & Yes & Yes & 2 & 1 & 1 & Yes & No \\
\hline $\begin{array}{l}\text { Forbes, } \\
\text { Michael }\end{array}$ & NY & 106th & $\mathrm{R}$ to $\mathrm{D}$ & $\begin{array}{l}\text { Appropriations; } \\
\text { Small Business }\end{array}$ & $\begin{array}{l}\text { Appropriations; } \\
\text { Banking and } \\
\text { Financial } \\
\text { Services }\end{array}$ & Yes & Yes & 2 & 2 & 0 & Yes & Yes \\
\hline Goode, Virgil & VA & 106th & D to I & $\begin{array}{l}\text { Agriculture; } \\
\text { Banking and } \\
\text { Financial } \\
\text { Services }\end{array}$ & Appropriations & No & Yes & 11 & 2 & 9 & Yes & No* \\
\hline $\begin{array}{l}\text { Martínez, } \\
\text { Matthew }\end{array}$ & CA & 106th & $\mathrm{D}$ to $\mathrm{R}$ & $\begin{array}{l}\text { Education and } \\
\text { the Workforce; } \\
\text { International } \\
\text { Relations }\end{array}$ & $\begin{array}{l}\text { Transportation } \\
\text { and } \\
\text { Infrastructure }\end{array}$ & No & No & 6 & 16 & -10 & Yes & No** \\
\hline $\begin{array}{l}\text { Alexander, } \\
\text { Rodney }\end{array}$ & LA & 108th & $\mathrm{D}$ to $\mathrm{R}$ & $\begin{array}{l}\text { National } \\
\text { Security }\end{array}$ & Appropriations & No & Yes & 5 & 2 & 3 & Yes & No \\
\hline
\end{tabular}




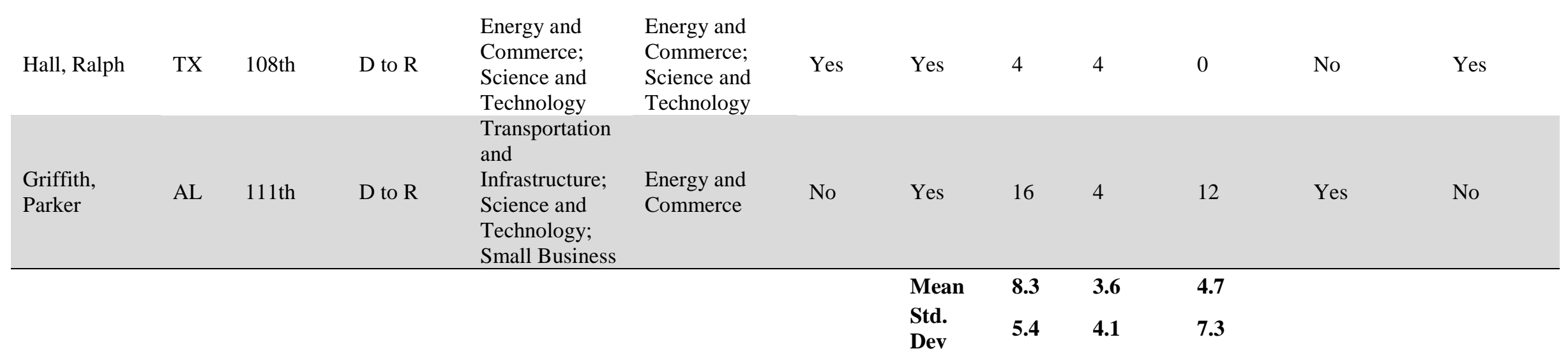

Sources: Nelson (n.d.), Stewart and Woon (2011), and Yoshinaka (2005)

*Virgil Goode retained his seniority, but only in his second, intra-caucus I to R switch.

** Matthew Martínez had already lost his Democratic primary, switched to the Republican Party, and decline a write-in bid for his seat when committee assignments were made in the $106^{\text {th }}$. 
In order to present the data in the most coherent form possible, I divide the results based on the years in which they occurred. Prior to the rise of a Republican majority in 1995, there was no clear trend showing committee seats being used as rewards for party switching. In fact, table 11 shows that the average party switcher during this era had his top committee assignment decline in rank by more than two positions, according to the Groseclose and Stewart (1998) ranking system. By contrast, table 12 shows that switchers who defected after the Republican Revolution improved their top committee ranking by nearly five positions, and nearly all switchers obtained or retained a top assignment. This may suggest that changes in committee assignment procedures and the rash of party switching that took place around the Republican takeover of the House in 1995 established an institutional precedent. When, with the help of other steering committee members, Republican Party leaders offered more valuable committee seats to all five House switchers in the 104th Congress, the result may have been to alert future party switchers to the possibility that their defections could result in institutional rewards. A member of Congress aware of these deals would be foolish not to inquire about the possibility of a top committee assignment when considering a change of party.

The Republican takeover of the mid-1990s is significant in this case not only because of the rash of party switching that occurred at the time but also because of coinciding institutional changes. When Newt Gingrich ascended to the speakership in 1995, he famously did so with a number of changes to the House rules. Among them was a major shift in the committee assignment process. Prior to these changes the House Republican Committee on Committees had made assignments for the caucus, placing the greatest among of committee assignment power with members of that committee who 
came from large states. Senior party members from states such as California and New York controlled the assignment process, and leadership influence over the process was diminished.

Under Gingrich, the Committee on Committees vanished and in its place was the Steering committee, on which the speaker held the largest number of votes. The process was and continues to be beyond the complete control of any single Steering committee voter, but the role of party leadership in the assignment process has been dramatically expanded (e.g., Aldrich and Rohde 1998). Whereas party leaders could not have truly promised committee assignments to prospective switchers following the end of Joseph Cannon’s speakership in 1911, that changed in 1995. Beginning in the 104th Congress, Gingrich could not promise but could strongly indicate his ability to sway the process one way or another. The result seems to have been that, for the first time, leaders had a considerable incentive to offer prospective party switchers. The fact that Gingrich was willing and able to negotiate on behalf of prospective switchers to give valuable assignments to former Democrats is an indication that he viewed the size of the caucus as a major concern. In fact, he was willing to upset longtime party members hoping for top committee assignments if he was able to slightly grow the size of the majority. What is more striking still is the fact that subsequent leaders and Steering committee members have followed suit.

The decision to grant a prized committee seat to a party switcher is not necessarily highly controversial in all cases, but it does tend to involve transactions or at least strong party loyalty by key party figures. In Michael Forbes’s case, for example, his post-switch Appropriations committee seat in the Democratic caucus came with the decision of James Clyburn (D-SC) to voluntarily vacate a seat on the committee in order 
to free it for Forbes. ${ }^{11}$ Clyburn was in a particularly strong electoral position, having been elected to South Carolina’s majority-African-American 6th district in 1992. As it was redrawn following the 1990 census, this was one of the safest Democratic seats in the country, and Clyburn won the general elections in both the preceding (1998) and ensuing (2000) elections with more than 70 percent of the vote.

Clyburn's volunteerism may have been the result of his electoral safety or of his general pattern of pro-leadership behavior characterized by, among other trends, a high level of party-sanctioned voting behavior. In fact, Clyburn's consistent party loyalty has placed him in the position of majority whip under speaker Pelosi. Clyburn's cooperation may be evidence of selfless promotion of party interests or of favor-trading with the aim of increased standing or influence. In either case, however, his willingness to cooperate with efforts to retain Forbes and his seat for the Democratic caucus is an example of the sometimes-subtle means by which party leaders can use their leverage or existing cooperative relationships to promote the interests of party switchers. More often there may not be members who feel so safe that they voluntarily step off top committees without some form of horse-trading or assurance of future reward. Leaders’ consistent willingness to broker such deals, putting switchers in valuable committee spots, is evidence that even small fluctuations in the size of the caucus are taken seriously by top legislative party officials.

The interaction between Forbes, Clyburn, and other top Democrats also illustrates a major challenge that arises for party leaders hoping to allow party switchers to retain their existing valuable committee seats. Although it may seem that allowing a member to retain a top seat requires less maneuvering than providing him a new seat, the challenges

\footnotetext{
${ }^{11}$ Forbes, Michael. Telephone interview. March 19, 2010.
} 
are roughly equivalent. This is true because the switcher's old seat was one owned by their former party in accordance with the overall distribution of seats in the chamber. The switcher's arrival in the new caucus means that in order to retain his previous seat he must displace either another committee member or a prospective member, depending on whether other members of the party's committee contingent leave the chamber or the committee. In some cases, expanding caucus membership due to electoral turnover may provide a steering committee with more valuable committee seats allocated to the party. In other cases, retirements, deaths, or electoral losses of committee members may open seats for incoming party switchers. However, in any of these cases leaders and Steering committee members must consider the number of ambitious party members who have waited for a spot on those committees and might take offense at being passed over in favor of a new addition to the party. Violations of Committee Seniority Norms for Party Switchers

Continuing the trend Yoshinaka (2005) reported, I find that party switchers are extremely likely to benefit from violations of the seniority norm. Most often this violation takes the form of retaining seniority accrued under the switcher's previous party affiliation. Twice as many House switchers as not in the post-Republican Revolution era were beneficiaries of violations in seniority. Those who were not rewarded in this manner included Matthew Martínez (CA), whose distinctive circumstances I have already discussed, as well as Wesley Watkins (OK), Rodney Alexander (LA), and Parker Griffith (AL). These last three members, although not rewarded with violations in seniority, did receive low-seniority seats on the Ways and Means, Appropriations, and Energy and Commerce committees, respectively. 
These results suggest that, at least in general, seniority violations were much more likely for party switchers than for the average House member. For a major portion of the postwar era, seniority norms in House committees were nearly absolute. In the era spanning from the 80th Congress (1947-48) to the 93rd (1973-74), seniority was violated on House committees a total of 14 times. In the aftermath of the 1974 congressional elections, the practice of violating seniority became considerably more frequent but still relatively rare. In the 30-year period ranging from the 94th Congress (1975-76) to the $109^{\text {th }}$ Congress (2005-06) House seniority was violated 79 times (Renka and Ponder 2007). Given that 1,426 members served in the House during this period, the rate at which members received rewards in violation of seniority was about 5.5 percent. Examining the members analyzed here, 11 of 20 (55 percent) House party switchers were rewarded in violation of seniority norms. Unlike rewards in switchers' committee memberships, these effects are relatively constant across the timeframe. Prior to the 1994 House elections switchers received rewards in violation of seniority in 4 out of 8 instances (50 percent), and post-1994 these rewards were given in 7 of 12 cases ( 58.3 percent). Whether viewed as part of a temporally segmented set or as a whole, it is clear that, although party switching does not assure a violation of seniority, it makes that outcome considerably more likely. In those cases where seniority was not violated, a switcher was often assigned to a more desirable committee. It may be true that relevant party figures do not feel the need to violate the seniority norm when a switcher is already receiving a better committee seat than he previously held. However, if that switcher simply retains a top committee assignment, those members might be more inclined to offer to let the switcher retain seniority so that the development does not appear to be a step backward in terms of institutional power. 
Although these kind of violations of institutional norms have become more common post-1994, they are still rare. Taken together, the frequency of seniority violations and the rise of top committee seat distribution to party switcher suggest that leaders value these new additions to the caucus to a degree that prompts them to fight to retain those seats. The explicit reason for this concern is not so clear as to be universally accepted or understood. Indeed, different leaders and Steering committee members may have dramatically different strategic considerations where these decisions are concerned. A committee member may favor a particular assignment as the result of some inducement, coercion, or the expectation of some unspecified future reward for party loyalty. Likely, individual decisions are based on personal efforts to balance ambition, party loyalty, and the perceived consequences of a particular vote. In any case, the data as well as anecdotal accounts from news accounts and members themselves indicate that institutional mechanisms over which party leaders have some control are disposed to favor party switchers over average party members. This indicates that leaders are willing to use what powers they have to attract switchers even when the real gain in caucus size and resulting party power is minimal.

\section{Summary}

The social environments of party switchers clearly shift in several ways following their decisions to defect. Among the most consistent changes are those pertaining to the social and professional spheres in which members operate. MCs who change party status work more frequently with members of their new party and less often with their former

partisans. Accordingly, the networks to which members belong shift predictably and in a partisan fashion. Members already facing different pressures from new voters and financial constituencies have their influence networks further altered by the introduction 
of new colleagues and altered working groups. It is a small wonder that, under these drastically changed conditions, MPR found the considerable changes in voting behavior that they did.

Few observers would likely suggest that these party switchers lose their own political identities completely. However, to the extent that these members are willing to negotiate, they seem willing to compromise in the opposite ideological direction (i.e., closer to the average position of their new parties). This effect may be the result of a bargaining process that contains new participants, many of whom are of a distinctively different ideological position than the switcher dealt with in his previous working relationships.

The degree to which partisanship guides interpersonal relationships within the legislature is striking for several reasons. First, it suggests that members take on new bargaining partners with differential ideological predispositions. Second, the group of peers with which members associated is formed in a manner that is significantly and independently partisan. That is to say that one can expect the exact same member with the same ideological attitudes to operate in different working groups on the basis of party affiliation. A wealth of research suggests strong relationships between group identity and evaluations of individuals, groups, and the credibility of both. ${ }^{12}$ Researchers have found that member of groups tend to hold views that favor ingroup members and disadvantage those perceived to be outsiders.

The tendency to favor ingroup members has been shown to be particularly strong in high-status groups (e.g., Brewer and Brown 1998). Although discussion of MCs as

\footnotetext{
12 For an overview of literature pertaining to the social psychology of group identity, see Lamont and Virág's (2002) discussion of the topic.
} 
high-status figures may bring to mind derogatory jokes, one would have considerable difficulty suggesting that position is not one of relatively high standing, American distrust of authority notwithstanding. The implication of this finding is that, especially for a member of Congress, group identity is likely to be important and influential. It is unsurprising, then, that this analysis shows that a change in group identity results in a change of interpersonal affiliation. This analysis also suggests that, in the post-1994 era, a party switch is likely to produce some significant event in a member's committee position or standing. In some cases this means an improvement in committee assignments. In others it simply means retaining a valuable seat at the expense of a new party colleague.

This kind of disruptive event is potentially meaningful to the MC's institutional, professional, and social roles. In other words, a party switcher not only is often given new influence within the chamber but also enters a new working group, namely a new committee or caucus. Given this fresh start, one would expect that an ideology-driven member would affiliate with the same types of colleagues as he had under the previous party label. This stasis is not apparent, however, in the findings presented here. Instead, one finds that resetting a member's working relationships under a new party label invites him to affiliate himself more closely with members of his new party. Whether or not this is an automatic response of innate social psychology is unclear. Existing literature suggests that this would be a reasonable hypothesis, although the precise answer is beyond the scope of this study. It is clear, however, that this social and professional shift accompanies a host of other environmental changes that manifest alongside altered legislative behavior. 


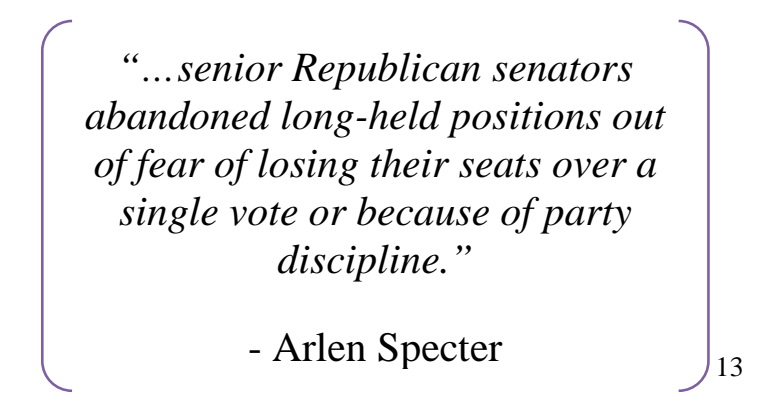

\section{Party Switchers in Their Own Words}

Few scholars doubt the usefulness of quantitative analysis as a means to test political theories, but there is considerable value to be found in speaking directly to the political actors whose behaviors and environments drive the theory presented here. There is little question that politicians possess their own motives in divulging information to an interviewer, but they also have information and breadth of experience that can be found in no data set. Taken together with quantitative analysis and further case study, their words can provide crucial insight to their own experiences, thoughts, considerations, and strategies. I spoke over the phone with several former members of Congress who switched parties while in office: former Representatives of New York Michael Forbes and Peter Peyser, former Representative of Pennsylvania Eugene Atkinson, former U.S. Senator from Virginia Harry F. Byrd Jr., and former Representative of Virginia Virgil Goode Jr. Although former Senator Arlen Specter declined my request for an interview and subsequently passed away, I was able to put together a considerable amount of qualitative evidence concerning the events surrounding his party switch and his public views on the subject.

\section{Michael Forbes's Switch: A Tough Fight in New York}

\footnotetext{
13 Specter, Arlen. Life Among the Cannibals: A Political Career, a Tea Party Uprising, and the End of Governing as We Know It. New York: Thomas Dunne Books.
} 
When I spoke with Michael Forbes, he mentioned tests of loyalty as a contributing factor to his departure from his party. Forbes represented New York’s 1st congressional district (on Long Island) and switched from the Republican to the minority Democratic Party in 1999. Forbes had been a member of the Appropriations committee as a Republican. He said that when he became a Democrat, James Clyburn (D-SC) stepped off the committee so that Forbes could retain his seat. This was done, according to Forbes, to help him in the next election, “to make sure that the majority couldn’t say that Forbes went out there and hurt his constituents, that he was so selfish in switching parties that he took the 1st district of New York and put it at a disadvantage.”

Forbes pointed to particular tests of party loyalty as influencing his decision to defect. When I spoke with Forbes, he suggested that Republican leadership in the late 1990s presented House members with a series of what he called "litmus test votes."

Forbes described one such vote:

There was an attempt to attach to the District of Columbia budget a prohibition that gay couples could not adopt children. And it was done simply to get people to show whether they thought that they would support gays or be against gays... these kinds of votes to see: are you strong on national security, or do you want to put America at risk? Are you for gays to adopt? How do you feel about gays in the military?

Forbes said that he found these practices by the majority to be abhorrent. I asked him what the response to an "incorrect" vote on such a measure would mean for a Republican member of Congress. He responded:

The whole leadership team comes down upon you, and they make it very clear to you that...you're putting yourself in a very vulnerable position if you don't support this initiative, because the radio and TV commercials will be run against you [saying], "Mike Forbes is for gays adopting children." 
The description of such tactics, if accurate, points to one clear answer to the question of how party matters-it matters to elites. One common theme in all of the interviews I conducted was that there was some political fallout, usually driven by party leaders either inside or outside the legislature. In this case, the greatest resistance to Forbes's decision came from both the leaders of the Republican Party in Congress and from state Democrats. Forbes's case points to another intuitive and recurring theme: Partisanship usually matters more to the majority. Majority parties in Congress are different from minorities in the tasks they undertake and in their overall goals.

In times of unified government especially, House majority leadership generally has an agenda that it expects to make some progress in advancing, whereas minority leadership is often relegated to organizing efforts to resist that agenda. Further, majority leadership tends to try to set the rules of the process and structure decisions in a manner favorable to the majority membership and unfavorable to the opposition (e.g., Cox and McCubbins 1993). Divisions in the partisan control of the House, Senate, and presidency of course complicate this relationship. However, it should come as no surprise that Republican leaders responded as strongly as they did in Forbes's case. The Republican House leadership was relatively strong in the 1990s. The partisan atmosphere was polarized enough that it led to, among other heated confrontations, the government shutdowns in 1995 and 1996.

As reported in an earlier chapter, Forbes received help from Bill Clinton despite his recent "yes" vote on the articles of impeachment facing Clinton. The opposition leadership also mounted a serious campaign to defeat Forbes. Republican leaders compiled video footage that included scenes of Forbes making rude noises under his 
armpit, and although they never aired the ad they created using the footage, one wonders if they would have had Forbes won his primary. The former congressman offered even more interesting revelations about the nature of Republican involvement in the campaign. Although newspapers reported that he declined the endorsement of the Right to Life Party, Forbes said that this claim was incorrect, saying:

I never rejected it. They rejected me...the Right to Life Party is owned by the Republicans in New York. There's no such thing as an independent Right to Life Party. They were basically controlled by the Republicans, and the Republicans basically told them, "Despite his 100 percent voting record in favor of pro-life issues, deny him the line."

Forbes went on to say that Republican elites actually helped to fund his Democratic primary challenger's electoral efforts. In a later email, Forbes clarified that the financial support had been funneled through from the national Republican organization through the state Republican Party. According to Forbes, the money was used in a targeted mail campaign aimed at alerting Democratic primary voters that he was pro-life and proSecond Amendment. These funds did not go directly to his primary opponent Regina Seltzer's campaign and was therefore not reflected in her financial disclosures to the FEC. However, a report in the New York Times confirmed Forbes's claim that Republicans at the national level indeed moved funds through the state party in an effort to influence the Democratic primary (Kelley 2000b).

\section{Arlen Specter's Switch: Fighting off the "Cannibals”}

Although Senator Arlen Specter’s office declined my request for an interview, his staff did refer me to a number of interviews the senator gave around the time of his switch as well as public statements he made on the topic. Specter was first elected in 1980 and spent more than 28 years as a Republican before becoming a Democrat in 2009. 
According to the senator, the Democrats saw him as a moderate and had been trying to recruit him for 5 years prior to his decision. Specter's case is notable not only because in joining the Democratic Party he pushed it to a 60 -vote supermajority but also because of a moment of public candor uncharacteristic of federal legislators.

Unlike most other party switchers, Specter cited his electoral prospects as a major reason for his decision. Specter went on to lose the Democratic primary to Representative Joe Sestak by about 8 percent. Sestak then lost in the general election to Republican Pat Toomey, who had nearly beaten Specter in the Republican primary 6 years earlier and was likely the source of the electoral anxiety that Specter expressed. Specter may also have been concerned about the potential candidacy of conservative activist Peg Luksik, who narrowly lost a bid for the 1990 Republican nomination for Pennsylvania governor (Balz 1990).

The 2010 senate race saw some controversy when Sestak claimed that President Obama had indirectly offered him a position in his administration in return for dropping out of the primary race. The administration noted its support for Specter early in the race but denied any wrongdoing when Sestak made the allegation. In statements Sestak and the administration later released, both said that Bill Clinton had contacted him, expressing concern for his prospects in the race and mentioning the possibility of Sestak serving in an unpaid advisory position in the White House. According to both statements, he declined, and the topic did not come up again (Feldmann 2010). The controversy died down prior to the start of the general election, but it is noteworthy that the administration felt a need to make that kind of appeal in support of Specter's candidacy. It is possible that Clinton and Obama were genuinely concerned about 
Sestak's strength as a candidate. Such concern would have been warranted as he eventually lost his bid for the seat. However, it is also plausible that the prominent Democrats intervened on Specter's behalf as a favor to a man who stood to be a 60th vote for cloture in the Senate and also stood a reasonable chance of reelection in a statewide general election.

When Specter announced his decision to switch parties in April 2009, he did so first in a written statement and later in a press conference. In his written statement, Specter made a nuanced argument in which he placed himself at the center of a partyswitching trend, noting that in the previous year "200,000 Republicans in Pennsylvania changed their registration to become Democrats” (Specter 2009). In that document he focused heavily on an argument that party switchers so often reference: a purported change in the ideological tilt of the party they leave.

The argument generally goes, “I didn’t leave the party; the party left me.” This element of Specter's message was far from unique, but two elements of the way he framed his message were distinctive. First, his language seems to suggest that, unlike most other switchers, Specter saw the ideological shift in his old party as something that was occurring at the level of the average voter, although his statements suggest that he also believed that elected Republican officials were becoming more conservative. Second, when Specter took the podium in his press conference, barely audible above the snapping of photos by a swarm of reporters, he was strikingly candid in forecasting a possible Republican primary. He used the word "bleak" more than once to describe his electoral prospects in the upcoming contest (C-SPAN 2009). 
This moment in political history was remarkable for its apparent honesty, but many saw the rhetorical move as a misstep. Specter tried to frame his message by saying that not just the party leaders, but the Republican Party membership in Pennsylvania had shifted. To Specter this appears to have meant that moderates left the party when it started to become more associated with the conservative Tea Party movement. Accordingly, since he said he had always been a moderate and a believer in the two-party system, the only logical choice was to join the Democratic Party. Unsurprisingly, Specter's primary opponent, Joe Sestak, was able to use Specter's statements to make a less nuanced argument: that “Arlen Specter switched parties to save one job...his” (The Real Arlen Specter 2010). The ad Sestak used to make this claim employed footage in which Specter specifically said the switch would allow him to be reelected, but as Specter pointed out, it took the statement somewhat out of context. The full quote seemed to suggest that he wanted to stay in office to continue helping the people of Pennsylvania (Levy 2010).

Sestak’s ability to characterize Specter as a Republican making a political move to save his job may have contributed to Specter's primary loss. The national trend of electing conservative Republicans that occurred in 2010 likely contributed to Sestak’s general election loss later that year. Specter ultimately decided to refrain from running as a third-party candidate. One additional effect of Sestak's attack was to prompt a response from Democratic Governor Ed Rendell. Rendell, who was set to step down in the same year due to term limits, came to Specter's aid, noting that Specter had supported Obama's stimulus bill, showing that he had the conviction to make risky votes in order to create jobs. 
It may have surprised some that Rendell so readily came to Specter's aid. In Rendell’s 2006 reelection campaign, Specter publicly supported his Republican opponent, Lynn Swann, advising him on how best to unseat the Democrat (Sherman 2006). Rendell's support also came in the form of a formal endorsement and seemingly endless attempts to speak to the press in aid of his party's newest member. Rendell's approach to Specter was emblematic of the broader Democratic support he received after leaving the GOP. Specter received endorsements from President Obama and Harry Reid as well, and both committed to campaign in Pennsylvania to support him. They followed up on this promise in a big way. In September 2009, Reid changed the Senate schedule to end voting early on the day Specter fundraisers were planned. Then President Obama and Specter traveled to Philadelphia aboard Air Force One and attended two dinners with Specter and Sen. Bob Casey (D-PA). The fundraisers netted the Specter campaign about \$2.5 million of the \$8 million it raised that election cycle, although he had a fairly significant war chest heading into the contest (Fitzgerald 2009a).

Although not legally obligated to do so, soon after becoming a Democrat Specter announced an offer to return campaign donations to anyone who asked for them. His staff announced early on that they had had few requests that donations be returned (Nunnally 2009). However, a push by one interest group, the Club for Growth, helped change that. The fiscally conservative 501(c)(4) group had been headed by Pat Toomey, the Republican candidate for Specter's seat, until earlier that year. After Specter made his switch, the group launched a campaign to remind Specter's Republican donors of his pledge to return funds if they were requested (Fitzgerald 2009b). 
The effort was hugely successful, and Specter had numerous requests for refunds. By the end of the election cycle, his campaign had returned more than \$3.7 million. The average incumbent running in 2010 gave contributors refunds of just $\$ 84,000$ (presumably for a wide array of reasons). In fact, the amount that Specter refunded in the 2010 race was almost twice as much as all other Senate incumbents combined. The impact on Specter's financial standing was clearly significant. The refunds he issued during the election cycle accounted for more than 27 percent of his total disbursements (Federal Election Commission 2011).

If he timed his switch with the intention of receiving as many favors from party leaders as possible, Specter did well in that regard. The Obama administration was struggling to find support for its healthcare reform plan in the fall of 2009. Polling suggested that the 2010 election would not be kind to Democrats, who still held sizeable majorities in both chambers. By March 2010, Specter was publicly arguing in favor of the bill, pushing the idea that Senate Democrats should take advantage of the budget reconciliation process to push healthcare reform through the Senate with a simple majority vote (O’Brien 2010).

When Specter was nearing the end of his final term, he spoke to the press on the subject of party discipline. His comments concerned what he perceived as a trend toward stricter enforcement of party discipline. Specter claimed that party leaders had prompted several senior Republicans to vote against their preferences out of fear of retribution from leadership (Hulse 2010). This feeling was so strong that although he had already written two memoirs, Specter decided to pen a third, titling it Life Among the Cannibals, a 
reference to his time in the Republican Party. He clarified his position on what he saw as runaway party power in his farewell address to the Senate:

The Senate rules allow the majority leader, through the right of his first recognition, to offer a series of amendments to prevent any other senator from offering an amendment. That had been done infrequently up until about a decade ago and lately has become a common practice...by both parties. By precluding other senators from offering amendments, the majority leader protects his party colleagues from taking tough votes (C-SPAN 2010).

Specter argues that this practice is stifling productive debate in the Senate, because, with no ability to modify legislation, senators are left with fewer options for compromise. He notes that this leads to minority party obstruction and generally reduces the prospects for the making of moderate policy in the chamber (C-SPAN 2010).

The senator went on to condemn the decline of various other norms of collegiality, eloquently arguing in favor of institutional features that encourage compromise and discourage polarization. A telling moment came when Specter said:

Senators have gone into other states to campaign against incumbents of the other party....Senators have even opposed their own party colleagues in primary challenges. That conduct was beyond contemplation in the Senate I joined 30 years ago (C-SPAN 2010).

Although Specter did not specifically say that these actions were taken against him, he may have been implying that members of his own party opposed him in his primary race. He may also have been referring to a broader trend in the 2010 election that ousted several more moderate Republicans in favor of conservatives. Specter characterized this trend by saying that Republicans valued “ideological purity” above other, more important characteristics. He called this impulse to oppose members of one's own party a form of "sophisticated cannibalism.” 
Specter's statements on party do not entirely support models of either strong or weak partisanship, but in his farewell address to the Senate and in his announcement concerning his switch he, clearly acknowledges growing polarization among the parties. He also acknowledges not only the importance of party discipline to party leaders inside Congress and out, but also the strong credence that senators give to threats made by those leaders. He specifically notes in his farewell address that he believes that members feared they might lose their seats as the result of discipline initiated in response to a single vote.

Other public statements by Specter suggest that he always acted independently of the parties to which he belonged. Of course this is a common claim. MCs who leave their parties tend to have been more moderate than the average member of their former party. As a result, they tend to have a good number of key votes on which they can show that they violated party discipline. When Specter switched, he pointed to his vote in favor of President Obama’s $\$ 787$ billion stimulus package as well as votes in favor of conservative causes. He presented this information as evidence of his independence in the face of party pressure. This kind of message is common among MCs in general and party switchers in particular.

As has been widely noted, many members of Congress run against the institution, capitalizing on its typically low public approval ratings. In order to do so credibly, MCs must represent themselves as independents, unable to be swayed by the Washington establishment. Party switching provides an opportunity to make that claim credibly, as the switch itself might suggest that one is above party labels. Moreover, the occasion presents a situation in which it is vital to express independence. If voters believe parties 
are important, they might also easily believe that switching one's party affiliation is tantamount to abandoning one’s principles. Indeed, the high rate at which party switchers lose their seats would seem to provide some evidence that such perceptions are fairly strong.

It is possible that Specter was embellishing when he made the series of strong statements that clearly claim that parties have become more influential over time. However, it seems clear that, at least from his perspective, not only was this the case, but parties had become increasingly ideological at the same time. His statements clearly indicate that he believes Republican senators were not satisfied with the presence of moderates in their caucus, viewing them as something less than genuine Republicans. Although this evidence for the strength of partisanship is anecdotal, it is a common claim and one that was echoed in my interview with Michael Forbes, as it has been in numerous media accounts.

\section{Harry F. Byrd Jr.'s Partisan Independence: A Success Story from Virginia}

During our phone interview Senator Byrd was quick to point out that he did not switch parties - he left them altogether. Byrd began his Senate career in 1965, but hi switched to independent status in 1970, his first reelection year. Republicans were gaining confidence in Virginia, having just won a gubernatorial election in the state for the first time since Reconstruction. As in other parts of the South, conservative Democrats had dominated the state for years. Byrd faced challengers from both of the major parties but impressively won a majority of the statewide vote, serving two more terms before choosing not to run again in 1982. As he put it, "No one before or since has run as an independent against nominees of the two major parties and has received a 
majority of the vote, more votes than the two parties combined.” His decision to become an independent may seem less noteworthy today (two subsequent defectors—-Jim Jeffords and Joe Lieberman—having made the move to independent status in the Senate), but at the time there was no question that the action was bold. Senator Byrd's approach to the 1970 campaign, his first as an independent, is striking in the political skill it displayed. Byrd framed his decision as a failure of the party system. He cast himself as an individualist, concerned with making common-sense decisions in the interest of his constituents and wholly unconcerned with the agenda of either party (Byrd 1998). I asked Senator Byrd why he left the Democratic Party, and he said:

The main reason was that the Democratic State Central Committee of Virginia passed a resolution that anyone seeking the Democratic nomination must sign an oath to support all the Democratic nominees for every office. Which would have required me [in 1970] to sign an oath to support for president whoever the Democrats might nominate in 1972 (two years hence). And after considering it, I decided I could not sign such an oath.

Byrd continued to caucus with the Democrats and received committee assignments with which he was quite happy. He noted, "I was a subcommittee chairman, and I was one of only three senators to have two of the top four committees, the top four committees being Appropriations, Finance, Armed Services, and Foreign Relations.”

Byrd faced some opposition in receiving those assignments, however. Five Democratic members of the Senate voiced their disapproval, but Byrd won the support of most other Senate Democrats. According to Byrd, Sen. Fred Harris of Oklahoma led his opponents. Harris also happened to be the chair of the Democratic National Committee from 1969 to 1970. Given the Senate’s reputation for collegiality, one might have expected other Democratic senators to accept Byrd uniformly. He had not diminished the size of the Democratic majority, yet he faced opposition to his retention of key committee 
positions. Many MCs who leave their parties do so after establishing a reputation of being relatively unreliable party supporters, so it is possible that Byrd's detractors had existing grudges against him and took action on those grounds. Regardless of these senators' motivations, however, a question is this: why did this group of Byrd's fellow partisans try to strip him of his committee positions only after he left the party? The timing of the action seems to indicate that, rather than being influenced by past dealings with Byrd, the party label itself mattered to those legislators. Of course the majority of senators voiced no opposition, so Byrd was allowed to retain his assignments. State Democrats, however, were sufficiently upset with his decision that they felt the need to support a new candidate in the 1970 election.

Despite some opposition from his former partisans, Byrd's is an unbridled success story. He made a bold political move and arguably picked his time and place well. One would expect that the partisan realignment that occurred in Virginia and throughout the country during this period had some effect. In Byrd's era, Republicans were becoming more conservative, but Democrats in Virginia were still quite conservative as well. Byrd took over the seat for his father, Harry Byrd, Sr., who had been a conservative Democrat and staunch opponent of desegregation in Virginia. The ideological similarities in the two Virginia parties in the late 1960s and early 1970s are illustrated by the ideology scores for the state's congressional delegations during these years. Members of both parties consistently received Americans for Democratic Actions (ADA) scores indicating that as a group they voted more conservatively than almost any other state delegation in the country (ADA 2011). The American Conservative Union (ACU) did not begin rating 
members of Congress until 1971, but when they did their assessments of the Virginia delegation as a whole and Byrd in specific were similar (ACU 2011).

Byrd's electoral success thus came at a time when Virginia Democrats were fairly ideologically similar to Virginia Republicans. Byrd did not need to worry as much as other switchers about upsetting Democrats in the electorate, because those conservative Democrats were likely less concerned with party loyalty than at any time in decades. Not only was it perhaps more difficult than ever to tell the parties' candidates apart at the state level, but at the national level Democrats had passed the Civil Rights and Voting Rights Acts just a few years prior, alienating many conservative southern Democrats and expediting the process of realignment. In this environment, Byrd had ideal conditions for making a seamless exit from his party, and his apparent skill in political communication no doubt helped.

It is with good reason that so many party switchers to the Republican Party came from the South. Their movement in that direction is emblematic of the underlying conservative ideology of the region. As such, for many southern MCs the decision to switch to the Republican Party fit their own political orientations. Moreover, the decision also posed less of an electoral risk because of the similarly oriented voters whose support they had to retain. Switchers of this stripe are often rebuked by elites but can generally take solace in the knowledge that their districts will understand.

This relative lack of party polarization, coupled with Byrd's decision to remain in the Democratic caucus, may have been the source of his success as a switcher. Both interest group ratings and DW-Nominate scores suggest Byrd already had one of the more conservative voting records in the Senate, a trend that was relatively unaffected by 
his decision to leave the Democratic Party. By several measures he became slightly more moderate in his voting behavior after becoming an independent. Why would Byrd have changed his behavior dramatically? He had a relatively ideologically homogeneous, conservative electorate. In this environment with fairly similar parties, one might imagine him achieving political success in either party or indeed as an independent. Unlike many unsuccessful party switchers, his defection likely did not appear to voters as a reversal of positions because (1) he did not join the other major party and (2) even if he had, at this moment in time that party probably looked like a close facsimile of the Democratic Party. Party switching in more polarized partisan climates, however, can be decidedly tricky.

Because voters tend to use party affiliation as a cognitive shortcut (e.g., Campbell et al. 1960), one would expect vote shares to vary significantly after a party switch. However, the level of partisanship in one area can be significantly different than another. I have already suggested that previous demonstrations of partisanship and race are two predictors of partisan responses to party switching. One might expect Virginia’s 9th congressional district to be relatively nonpartisan based on its overwhelmingly white population, but Senator Harry Byrd had a different impression of the region. He said of the district:

They don't believe in independents-don't know what one is. Out there you're either a Republican or you're a Democrat. And I have made many friends in both parties out there, but all of them said, "We'd prefer you not come out here. We can’t afford to be seen with you.”

I asked Byrd how he knew the region would be tough to win as an independent, and he did not have a simple answer. He said he had been in politics a long time, and he knew an independent would be a tough sell there. This idea that some regions are simply 
partisan is an intriguing one, because it offers the opportunity to examine regional variation in an attempt to find further predictors of constituent partisanship.

\section{Virgil Goode Jr.: Another Winning Approach in Virginia}

It is difficult to examine the facts of Virgil Goode’s political history without being reminded of Senator Byrd's story. Both began their political careers as Democrats in the Virginia State Senate, and both later switched to independent status while holding office at the federal level. Byrd and Goode also had relatively conservative voting records, although rank-ordered estimates of Goode’s pre-switch ideology suggest that he began significantly closer to the middle of his chamber than Byrd did (Rosenthal and Poole 2011). Goode, however, served in Virginia’s 5th congressional district rather than in the Senate. He also eventually transitioned to the Republican Party, moving to independent status in 2000 and to Republican status in 2002. Goode’s district remained relatively Democratic even well after realignment occurred in the South, and it contained about twice the percentage of African-American residents than the country as a whole. The district contains a broad portion of rural central Virginia, but it also contains the city of Charlottesville, home to the University of Virginia.

In our phone conversation, Goode described his relationship with the Democrats and the Charlottesville area of the district this way:

Some of the Democrats were very mad, because I voted in the House to impeach [Bill] Clinton. They were mad about that. Of course they didn't like me being conservative on a number of issues. So especially in the CharlottesvilleAlbemarle area they were mad, I think, that I switched. Some people to this day are mad with me because I switched.

Much like other switchers, Goode roused the ire of his party, but it is worth noting that Goode’s characterization suggests that although Democrats blamed him for being out of 
line with their party, they may have taken greater offense to his decision to leave.

Goode's decision to join the Republican caucus may have been part of the motivation for this sentiment (Abrams 2000).

When asked, Goode also pointed to one key demographic change in his electoral support:

As a Democrat, I had about 95 percent of the African-American vote. As an independent that fell down to 20 percent, and as a Republican fell down to probably 10 [percent]. And last time...maybe 3 or 4 [percent] if I got that much. African Americans, in my experience, will vote straight party.

This idea is not new, but party switchers provide an interesting test of the strength of party voting among African Americans (American National Election Studies 2010). Goode’s anecdotal account of his move from garnering near-unanimous support from the African-American electorate to nearly no support is a strong indication of how much the party label means to African-American voters. Goode pointed out that he did not feel the job itself changed at all. He got better committee assignments, taking the Republican spot on the Appropriations committee vacated by fellow party switcher Michael Forbes, but he was not charged with a different task than he had been. Many switchers would no doubt echo this sentiment. The job itself does not change when you switch parties. However, elements of the political environment clearly do. Party switchers are still charged with representing constituents, and many MCs take that duty seriously regardless of the party to which they belong. However, the character of one's reelection constituency undoubtedly influences the task of representing constituents. A pro-gun control Republican in a polarized district might feel compelled to oppose gun control legislation in an effort to act as a delegate for her district, but if she switches to the Democratic Party_-to a constituency whose preferences now match hers on the issue- 
she would have no reason to violate her own preferences in service to the district. Thus the question of how partisanship affects representation depends in part on the role the legislator has adopted.

Representatives who more closely fit the trustee template are less likely to be strongly affected by partisanship because they base their behavior on internal preferences, which are unlikely to shift dramatically with a change in party label. By contrast, one should expect prototypical delegates to alter their behavior in accordance with the degree of change in their partisan environments. Even if Harry Byrd fit perfectly in the mold of delegate, one would not expect wholesale changes in his behavior because there is little reason to believe his reelection constituency as an independent was drastically different than it had been as a Democrat.

\section{Peter Peyser: More Tension in New York}

Peter Peyser was among those to rouse the ire of party leaders when he decided to become a Democrat after serving three House terms as a Republican. As he told me, "Whenever you make a move like this you get a reaction, really from both sides." According to Peyser, those reactions took multiple forms. Some Democrats, he said, were not happy to have a new Democratic candidate whom they saw as an intruder. Republicans, however, reacted in a manner that hurt Peyser electorally: The Republicancontrolled New York state legislature eliminated Peyser's district in 1982. The word he used to describe the move was "revenge." He explained the form this revenge took:

They gave me a sitting congressman, a popular congressman, gave me his whole district to run against him, which I did. And I lost, but we came very close considering...Ben Gilman (R-NY), had been in Congress many years. 
For Peyser, the move to eliminate his district may have also ended his career in the House. Although some Democrats at the state level were upset with Peyser's arrival in the party, he notes that he received the support and endorsements of key Democratic figures within the legislature, including then-Speaker Tip O’Neill and then-U.S. Senator Patrick Moynihan.

Peyser's case could not have been a clearer case of elite partisanship, and the influence of those elites profoundly affected Peyser's electoral fortunes. Much like Michael Forbes, Peyser drew considerable ire from Republicans and the new embrace of Democrats. In neither case did the change result in electoral success, but in both partisan groups used considerable power to influence the course of the first post-switch election. In Peyser’s case, he was invited to join the party by Speaker O’Neill and Majority Whip John Brademas. As for the Republicans response: He actually lost his political home with the elimination of his district and faced a congressional incumbent. In short, many if not most of the factors that contribute to incumbents' electoral success disappeared in the wake of Peyser's move across the aisle. As a Republican, Peyser had been a less than ideal legislator in the eyes of his fellow partisans. As a Democrat, they made unseating him a mission, one they carried it out effectively.

Within the chamber, Peyser noticed some changes in how he was treated, mostly by members of his new party. Speaking about his relationships with fellow legislators, he said, "I think the Democrats were delighted to have me and made it very clear. And the Republicans, many who were friends, didn't want me to do it, but I would say, didn't get too excited about it.” Most party switchers express some gratitude to their new colleagues. This may be due in part to the fact that many receive favors from the new 
party, such as valuable committee assignments or favorable violations of seniority norms. In Peyser's case, the findings of the previous chapter show that his overall committee position slightly improved. The greater influence for him seemed to have been the warmth he experienced being welcomed into a group of which he felt a part. At one point in the interview his partisan pride was especially apparent as he asserted, “ I am a Democrat.”

Elite partisan influence in his case was undeniable, but, accord to Peyser, he also experience shifting support at the grassroots level. I asked Peyser about changes to his fundraising portfolio, and he said he didn’t get much financial help from the party. However, he added, "What I did get was a lot of support from labor and a number of groups that were certainly Democratic.” This comment hints at the effect demonstrated in the fundraising analysis presented above. Labor unions support Democrats at a much higher rate than Republicans, and the groups have more to offer than just funds. Unions can also mobilize their members to provide support on the ground, and Peyser hinted that this was the case following his switch. In today's political environment, both labor and corporate concerns can further involve themselves in anonymous funding of campaignrelated ads, leaving the door open for even greater influence guided in large party by party affiliation.

\section{Eugene Atkinson, Ronald Reagan, and the Struggle to Save Steel in Pennsylvania}

Listening to Eugene Atkinson, one predictor of the magnitude of partisan response to a party switch might be the presence of strong labor unions in a region. The strength of unions and the success of Democrats in Atkinson's district went hand in hand. Of the voting behavior in his home county (Beaver County, PA) Atkinson said, "In local 
elections, facetiously, we'd say we didn't count the ballots, we just weighed them. That's how heavy Democratic favor was.” During our phone conversation, Atkinson spoke frequently of his interest in saving the steel mills in his district and mentioned many times the influence of organized labor.

I asked Atkinson if his electoral efforts might have been more successful had he become an independent rather than a Republican. He responded saying that his district was “a ' $D$ ' or an ' $R$ ' area.” According to Atkinson, his district's partisan leanings were founded in the Great Depression and continued in that vein even during his own congressional career (1979-82). He described the character of the district by saying, "They vote Democrat because of past situations and particularly their hatred for the Republican Party from the Hoover days on.” He suggested that the continued Democratic leanings of his district were also linked to the unions.

While still a Democrat, Atkinson had voted with Republicans on issues such as workman's compensation. He said, "I guess that made me a company man in the minds of some," but he was quick to point out that he made the votes he did based largely on his desire to keep jobs in the district. When I asked Atkinson what groups he had difficulty winning over as a Republican, he put it simply: "It was organized labor.”

Although many advocacy groups are not expressly affiliated with one party or another, groups learn through their experiences dealing with political parties. Labor unions are not expressly Democratic groups, but they know that Democrats are generally more supportive than Republicans of their preferences. As a result, such groups tend to view switching parties—-particularly moving from one major party to the other—as an indication that a legislator is changing policy positions. Depending on the party to which 
the member switches and the position of the group, such a move could be favorable or not. However, labor groups likely see a switcher to the Democratic Party as a potential source of increased support for their policy goals. As Nathan Deal's case suggests, those same groups can react negatively to a move to the Republican Party. Whether this reaction is a response to the perceived change in policy position by the member or the prospect of a more labor-friendly Democratic candidate is irrelevant to this analysis if the reaction comes in response to the act of changing parties.

The statements by party switchers with highly partisan interest groups in their districts suggest an effect that may mirror the larger reaction of the electorate to the act of switching. Regions with high levels of partisan polarization, be it at the level of individual party identification or of interest group party preference, are likely to view switching from one major party to the other as negative on a number of fronts. First, a polarized population is more likely to have distaste for the other party's label and anyone who runs under it. Second, switchers operating in polarized atmospheres might think it wise to make major changes to their behavior and rhetoric to court their new, much different party. Too little change in approach may alienate an MC from those who identify with his new party, but too much change can be easily exploited by an opponent who wishes to portray him as a "flip-flopper." This dilemma was keenly illustrated in Michael Forbes's case. In spite of support from Bill Clinton, he failed to receive the support of the leading state Democrat in New York, who, by all accounts, saw him as too conservative for the party. Last, in many cases, switchers operating in polarized environments must deal with groups that strongly identify with one party or the other. 
In his demographically and ideologically homogeneous North Georgia district, where Democrats and Republicans were likely both relatively conservative, Nathan Deal faced ads sponsored by the AFL-CIO, but the tactic had little effect. Not only are union members rare in Georgia—the state was tied for the second least-unionized state in the country in 2010 according to AFL-CIO estimates— but the organization's ideological leanings are arguably out of line with the political character of the region.

Unlike Deal, Eugene Atkinson operated in a district in which unions held considerable political sway. Atkinson says he knew that becoming a Republican meant big trouble for his political career in western Pennsylvania. The way he saw it, working with Republicans as a Republican was the only way to save the steel industry in his district. As a Democrat, Atkinson had stood with the Carter administration, against the will of unions in his district. He authored a plan to save the steel mills in his district and passed it on to the First Lady, asking her to give it to President Carter. The administration took no action on the issue, and Atkinson blamed this inaction for the subsequent decline of the industry in his region. In the figure of Ronald Reagan, he saw new potential to better the economic condition of his district. Soon after John Hinckley Jr. shot and wounded him, Reagan called into a radio show on which Atkinson was being interviewed. Reagan and Atkinson established a working relationship starting with this call. Atkinson believed an executive order from Reagan had the potential to save the steel industry in western Pennsylvania.

Atkinson's interactions with the presidents may have influenced his decision to become a Republican, but his shifting perceptions of the parties likely played a significant role as well. Speaking about his new party, Atkinson said, "My understanding 
with the Republican Party [was that] they favored things that created business.”

Although Atkinson's district, Pennsylvania's 25th, was not completely dominated by

Democrats, ${ }^{14}$ it was held predominately by Democrats starting in the first year of the Franklin Roosevelt administration. The district was eliminated in 1983 as a result of the 1980 census, and Atkinson was forced to find another district (Martis 1989), choosing to run in Pennsylvania's 4th and losing with less than 39 percent of the vote (Clerk of the House of Representatives 1983). Atkinson reiterated the importance of a team mentality in the partisan congressional structure. He noted that he had voted against Tip O’Neill and the Democratic leadership on many occasions. Speaking of the Democratic leadership, Atkinson said, "You're either with them or against them...I was against them, and they went against me.”

\section{Psychological Impact of Group Membership}

Team mentality was a key theme among many of the switchers with whom I spoke. Michael Forbes described the behavior of the Republican Party in the late 1990s this way:

We did things in the House of Representatives during the Gingrich years and subsequently that have been done in politics for all of eternity, and one of those things is that, you know, you're constantly challenging the other team. You want to put them in embarrassing positions. You want them to cast votes on things that can be used against them in the future.

This type of legislative tactic is familiar to scholars of Congress, but the manner in which Forbes describes it may be telling. Forbes depicts a scenario in which teams are competing with one another. This may or may not mean that an individual legislator sees members of the opposing party as rivals—indeed, most have at least some friends across

\footnotetext{
${ }^{14}$ Republicans held the seat from 1945 to 1955 and from 1975 to 1979.
} 
the aisle. The organization of Congress by party does, however, seem to cast Democrats as the outgroup in the minds of Republicans and vice versa. The effects of group membership on perceptions of other groups is well documented (e.g., Brewer 1979; Lemyre and Smith 1985; Tajfel 1970) and generally suggests that when major differences are perceived between groups, behavior is subject to group influence. In short, certain key interactions between individuals that are perceived to be important to the groups will focus not on individual characteristics but on group characteristics.

This theory does not suggest that Republican Smith will never get along with Democrat Jones, but it does suggest that in important legislative interactions they will treat each other as Republican and Democrat rather than simply as Smith and Jones. Both Atkinson's and Forbes's language suggests that this may be the case. The effect of this group mentality may indeed be enhanced by the existence of leadership structures that benefit from party unity and larger majorities. Forbes noted that the clear objective of Republican leadership during his tenure was to make sure that Republicans "play[ed] ball.” Those who did not go along would not necessarily experience dramatic retaliation — being stripped of a committee seat, for example — but they might draw the ire of the leadership in more subtle ways. According to Forbes:

There's a certain way that [the party leadership] kind of [puts] a fence around you. And believe me, there are members of the caucus in the Republican conference who are such loners. They're in the same seat, and they don't give money to the party, but they don't get a lot done to be honest with you.

This explanation of the exercise of party power suggests that although a party does not often publicly reprimand its own, simply doing nothing to help a member may be incentive enough to make her "play ball." If a legislator accepts this premise, that parties need to act collectively and strategically, seeing the members of the other party as the 
opposition may be a small cognitive leap. The structure of the House in particular is conducive to this mentality. The majoritarian nature of the House often allows the majority to steamroll the minority before both parties have a chance to influence legislation in the Senate. In such an environment, especially one that also satisfies the criteria required for conditional party government, one should expect the majority to adhere more strongly to a team mentality. In short, it is more fun to be on the winning team, particularly if you do not identify well with the losing team.

In Eugene Atkinson's case, however, he saw the strength of political leadership coming from Ronald Reagan and not from then-Speaker of the House Tip O’Neill. Atkinson clearly saw Ronald Reagan's “team” as more capable, and although he switched away from the majority party in the House, he did so at a time when the political tide seemed to be changing in favor of Republicans. On the issue of O'Neill's leadership, Atkinson said:

The Reagan agenda made him the weakest speaker you could ever imagine. He couldn't bring anything through. He pretty much admitted it whenever he was talking to President Reagan...

Atkinson stressed that he had no personal animosity toward the speaker; they just disagreed on the issues. Michael Forbes seemed to see the leadership of Newt Gingrich as more oppressive than constructive. For Forbes, the mode of thought that characterized House Republicans’ team mentality put him on the outside. In a relatively polarized Congress and under strong Republican leadership, drifting to the center was, according to Forbes, not tolerated. In both cases, the legislators abandoned the majority for the minority party, ostensibly on principle. In both cases, the minority seemed to offer the members new freedoms that they had not enjoyed under the majority party's banner. For 
Forbes, this meant freedom from having his party standing determined by litmus test votes and the liberty to pursue policy goals that contradicted those of the Republican leadership. Forbes's case suggests that, in a strong majority regime, minority status allows members greater ideological latitude. For Atkinson, it meant the freedom to work with the Reagan White House to save western Pennsylvania’s steel industry.

Atkinson's case demonstrates a perception that the Reagan administration would view Atkinson's new Republican status positively. Atkinson could have chosen to remain a Democrat but still work with the Reagan administration, but he instead chose, heavily influenced by his belief in Reagan's agenda, to become a Republican, a decision one could not have reasonably believed to be a hindrance to their relationship.

If one examines its institutional features, the Senate ought to provide an atmosphere in which group characteristics of all kinds are less salient to legislators. Each senator wields considerable negative power over the legislative process, and scholars generally consider it to be a more collegial body. Collegiality and individualism are not conducive to the kinds of ingroup and outgroup cognitive classifications that affect the House when it is sharply divided. Although I spoke with just one senator who changed his party status, his comments largely support the notion that the Senate is different. Harry Byrd Jr. mentioned the failed effort to deny him the committee seats he had held as a Democrat, but he seemed to have little else to say about the fallout amongst his colleagues in the chamber. It is worth noting, however, that all Senate party switchers for whom I produce social network data follow the predicted pattern. Whether or not the reaction to a senator's party switch affects his colleagues' perceptions of him, the switch appears to affect with whom he works. 
The psychological impact of Arlen Specter's party switch was clear on the day he announced it. In his 2012 memoir Specter noted that the mood was well-reflected in a quote from Republican media advisor Mark McKinnon, who, although not an elected official, was a party switcher himself. McKinnon was quoted in a New York Times article, saying that party switching is characterized by “[r]ejection, betrayal, humiliation, jealousy and anger for the aggrieved party...[j]ubilation, titillation, pride and power for the successful seducer” (Leibovich 2009). Specter noted that just hours after his decision to switch became public, Republican leadership let his committee aides know that they should stop working for him, because Republican funds could not be put toward helping a Democrat (Specter 2012, 201). In all likelihood, an immediate and complete work stoppage like the one Michael Forbes experienced would not have substantially affected Specter's chances of retaining his seat, but it seems clear that the scorned party wanted to send a message.

Shortly after the official party switch announcement, National Republican Senatorial Committee chair John Cornyn said, “...Specter’s decision today represents the height of political self-preservation” (Jacobs 2009). Specter responded to these comments years later by saying that "Cornyn was a friend, and he might have toned down his remarks” (Specter 2012, 202). According to Specter, the NRSC went on to bombard Democratic voters in his state with phone calls indicating that he received support in his previous reelection bid from both Bush and Cheney. The tactic was reminiscent of the GOP push against Michael Forbes in New York, although that effort used direct mail. Specter also said that, soon after his announcement, he asked Senator John McCain for 5 minutes to speak on the Senate floor. Specter said that “...McCain indignantly told me to 
get it from [Harry Reid (D-NV)]” (202). Specter’s account illustrates the level of frustration and even hostility that his decision evoked. One struggles to imagine that this level of animus was solely the result of a Republican urge to have a slightly larger minority in the chamber. It also seems unlikely that Specter experienced this kind of treatment even when, as a Republican, he decided to vote with Democrats on key legislation.

\section{The Elusive Effects of Political Culture}

Political culture is a perplexing area of inquiry for political scientists. One prominent study linked individuals' states of residence with their party identifications and ideologies, suggesting that regional culture has some effect on political orientation (Erikson, McIver, and Wright 1987). Some scholars have made headway identifying regional types of culture, finding differences, for example, in regional perceptions of political efficacy and citizen duty (e.g., Patterson 1968). However, the concept itself remains nebulous, and efforts to quantify it are inherently confounding. Nevertheless, the issue of regional cultural variation remains a factor in the minds of some of the legislators with whom I spoke.

The subject arose in questions of the public reaction to candidates becoming independents. Eugene Atkinson described his entire district as “a ' $D$ ' or an ' $R$ ' area.” The concept of independent representation, he said, was one that just was not accepted in the district. This could perhaps be said of the country as a whole. The major parties have gradually fallen out of favor with many voters, and politicians operating within the confines of a two-party system regularly claim "maverick” status, suggesting that they vote according to conscience, not the party line. Nevertheless, few politicians choose the 
independent label for their own campaigns. Harry Byrd adopted this label with great success, but he noted that he represented one region that he knew would be tough to sell on the idea of an independent: Virginia's 9th congressional district. ${ }^{15}$ In his words:

In the 9th congressional district, you were either a Democrat or you were a Republican. There was no such thing in their minds as an independent. I knew that from the beginning. I felt that I could win the election if I didn't lose the 9th by more than 20,000 [votes]. I lost it by 3 [thousand].

I asked Byrd how he knew that the district would not support an independent, and he told me that he had been in politics a long time and he just knew that “they don't believe in independents—don't know what one is.” A full analysis of the potential causes of purported 9th district mentality is beyond the scope of this study, but the suggestion that some pockets of political culture may be more attached to the party system as a cognitive schema than others is interesting.

One interesting feature of Virginia's 9th district is that it largely rests upon the Southwest Virginia Coalfield, making the district the source of nearly all coal mined in the state (Virginia Department of Mines, Minerals and Energy 2006). It is possible that the type of industry-focused concerns that painted political party as a black and white issue for many voters in Atkinson's steel-centered Pennsylvania district did the same for the coal-producing Virginia district. In these districts the primary political question may be: What will you do to advance our industrial workforce? If this is true, the idea that voters might see one party or the other as the industry's best bet for federal help may not be far-fetched. Without more intensive study, however, these ideas are purely speculative. Virginia's 9th does not have a history of single-party control, but it does tend to hold onto one legislator over extended periods of time. When Byrd ran for

\footnotetext{
${ }^{15}$ Virginia's 9th congressional district occupies a large corner of southwest the state and includes towns such as Bristol and Blacksburg.
} 
reelection in 1970, Republican William Wampler held the seat (from 1967 to 1983). When Wampler was finally defeated in 1983, he was replaced by Democrat Rick Boucher, who held the seat until 2011, when he was unseated by Republican Morgan Griffith (Martis 1989).

In his 2012 memoir, Arlen Specter described an unspoken sense of ideological agreement on the Republican side of the aisle. He noted:

I had never really felt comfortable in the Republican caucus. I made many friends, but I didn't speak up much at weekly policy lunches and other gatherings, because I knew that what I had to say would not be well received (185).

Specter said that he suspected his discomfort within the party was apparent to others, because Democrats eventually began making appeals that he switch sides. One wonders if Specter would have had a different experience if he had served in a previous era. A less polarized partisan environment seems far more likely to foster less striking partisan differences, and increased similarity (real or perceived) might be expected to foster a shift in the social psychological effect that comes with group identity.

\section{Summary}

When parsing the statements of legislators who simultaneously claim to be independent and that parties use their power oppressively, it is useful to note that a switcher's actions tend to suggest that he believes his independence cannot be maintained as a member of his original party. In Arlen Specter's case, the decision likely had more to do with remaining in the chamber than maintaining independence, but for most switchers the same cannot be said. Leaving one's party is generally a tremendous electoral risk, one that could be easily avoided by staying put. 
The fact that MCs choose to switch is itself an indication that parties are important to members' success in achieving their goals. The ways in which this is true, however, are often complex and nuanced. A member's decision to leave a party may be influenced by a perceived personal or professional slight or a desire to escape the influence of that party's leadership. The draw of a new party may be its majority or minority status, the personal appeal of that party's membership, or promises of new favors from party leaders. The decision may result from genuine conviction or political expediency.

In Eugene Atkinson's district, it is probably safe to say that becoming a Republican was a risk most self-interested legislators would not have taken. In a traditionally Democratic area purported to be heavily influenced by organized labor, he made a decision that seemed to be based more on conscience than on self-preservation. The result was a quick end to his political career. However, he made the decision because he believed he could be more effective in a new party, one with which he shared key values. In our interview he indicated that he believed joining the Republicans would help his standing in Washington. He saw Reagan as a figure capable of making progress in a direction he believed would be unattractive to Democrats. Cases such as Atkinson's show the role that personal interaction can play in legislators' perceptions of the parties. Far from seeing parties as bodies defined purely by ideology, many party defectors discuss the role of specific events in driving them away from a party. Michael Forbes describes a Republican majority under Newt Gingrich in which fellow partisans were subjected to tests of loyalty. Harry Byrd left the Democratic Party in large part because of a loyalty pledge he was unwilling to sign. These were developments with which 
legislators took issue on principle, but one could sense a personal element to these events as well.

Similarly, the appreciation that switchers have expressed about members of their new parties is clear. Presidents and party leaders alike regularly campaign in support of switchers to their party. Whether out of personal enmity or political opportunism, key leaders often seek to defeat decisively legislators who defect from their party. That party leaders see switchers as vulnerable is unsurprising, but the intensity with which they attempt to unseat defectors to the opposing party is considerable.

This drive to send a message to other potential switchers was on display in the Republican response to Michael Forbes's switch. Leaders not only set out to defeat him in the general election (apparently preparing to run a particularly personally embarrassing ad), but they actually funded efforts by his Democratic opponent. The Republican leadership contributed to a primary defeat at the hands of an elderly challenger whose only political experience came at the municipal level. In the end, Regina Seltzer defeated Forbes by 35 votes and then lost decisively in the general election (56 percent to 41 percent). Republicans' desire to aid Seltzer may have been driven in part by a desire to face a weaker opponent in the general election, but the words of the chair of the House Republican Campaign Committee likening his view of Michael Forbes to the movie Dead Man Walking —a tale of a man awaiting execution—clearly communicated the vigor with which he intended to attack the newly minted Democrat. The comment, taken together with the strong public reactions party leaders, pundits, and staffers regularly display to a switching event, hints at a prevailing and decidedly partisan culture. 
Although no one can adequately summarize an entire political culture in a single chapter of a study such as this, it seems appropriate to say at least that many observers in and out of Washington take umbrage at the decision to abandon a party. Under rare circumstances and with exceptional communication skill, some MCs have overcome the tension naturally produced by such an apparent change in preference. Those who have accomplished this feat have done so in part by remaining within the party caucus or by simply having a district favorable to their new political identities. The abject political failures that occur happen in part because a switcher is so easily painted as a person without conviction, an opportunist whose trustworthiness is questionable at best.

The truth of these claims is of course a matter of opinion, but the political awareness of this vulnerability is beyond question. Such a political liability would simply not exist if voters saw parties as interchangeable. No one would claim that a party switcher was abandoning his constituents if it was a claim unlikely to gain traction. Combine the fact that voters are largely driven in their individual voting behavior by partisanship with the wealth of evidence for the significance of constituent pressure. The result is that one can easily observe the impetus for a party switcher to simultaneously change his legislative behavior to appeal to his new base and also publicly claim maverick status to alienate as few of his former supporters as possible. For legislators, who are so dependent on a network of support from fundraisers, voters, staffers, media figures, and partisan higher-ups, a party switch irreparably changes the character and makeup of that entire network. A switcher can take a few steps to combat the vulnerability this network shift creates, but he cannot stop the turning of the political tides. 


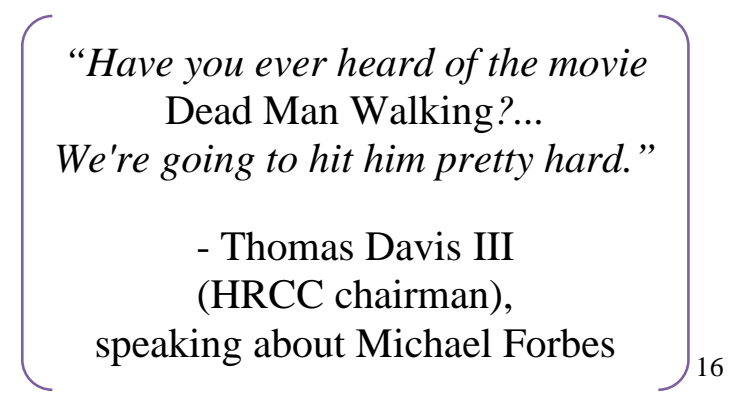

\section{Conclusion}

Scholars have long suggested that American political parties affect not only the organization of government and the execution of elections but also individual-level thought and political behavior (e.g., Key 1964). Accordingly, there are many ways in which parties and party labels affect politicians and the pressures they face in their political environments. In the course of this study, I have provided evidence for a number of those effects. The reliability and in many cases the magnitude of these partybased shifts in influence systems is profound. These changes leave little doubt that a congressional party switcher feels the political terrain moving suddenly and dramatically beneath his feet.

In part, this study shows disparities between the levels of funding that MCs receive from corporate and labor groups before and after switching their party status. Those differences are reliably evident in the expected directions. An average party switcher can expect his donor pool to change significantly and predictably. Rodney Alexander's case is an excellent example of the considerable impact of party affiliation on both funding and the behavior those funds are intended to support. Alexander made a point of publicly priming labor donors to continue accepting him as a favorable representative. Briefly before switching parties in a manner obviously timed for political

\footnotetext{
${ }^{16}$ Alvarez, Lizette. August 7, 2000. “G.O.P. Aims For Revenge On Defector In Congress,” New York Times.
} 
advantage, Alexander spoke glowingly to the press about his commitment to organized labor. Soon thereafter, he became a Republican and lost the vast majority of his labor funding. If the interest group ratings he received on the basis of subsequent votes were any indication, he also dramatically changed his behavior with regard to issues of concern to labor unions. In short, even with public assurances about his continued support for organized labor, groups determined that his changing party affiliation was an indication of broader changes in political priorities.

Although clear links between financial contributions and voting behavior are not prevalent in existing scholarship, it is clear that contributions at least buy access. When an MC sits down with a telephone and starts the almost-daily process of seeking campaign funds, the voices he hears are a significant part of his environment. When he frequently attends fundraisers with both donors and lobbyists, those experiences are a major part of his environment. Change the types of people and groups involved in these activities, and you change the world in which he operates. Even if he holds to his core principles, he may compromise on others or even fundamentally change his views. The likelihood of this kind of change occurring is likely higher among party switchers than other groups in Congress.

Beyond the simple relationships (or lack thereof) between campaign contributions and voting behavior, recognizable shifts in the types of groups supporting an MC ought to change his expectations concerning future professional opportunities. This is of course particularly true in the field of lobbying, although former legislators often also take positions in consultant roles, for example, that allow them to benefit from political connections and policy expertise but do not explicitly involve lobbying practices. If 
expectations concerning these future employment opportunities are as important to MCs as their rising ubiquity would indicate, major shifts in organizational support are important. Because I find precisely the types of shifts that might change the range of organizations in which a legislator can seek employment after leaving office, this should certainly be considered a major potential source of behavioral influence, based in a distinctly partisan environment.

This study finds that a switch in party affiliation reliably alters the social networks in which legislators operate. Even holding the legislator himself constant, a member who switches to the Republican Party begins to work more frequently with Republicans, and a new Democrat does the same with his new partisan colleagues. Even if one were to suppose that campaign donors are a persuasive—if somewhat infrequent—source of potential pressure, professional colleagues may be much closer and more constant sources of influence, if only because of the frequency with which they interact. Some of that influence comes from party leaders, who explicitly work for and indeed define partisan interests.

The qualitative and quantitative evidence that I present show that, in the modern Congress, those same leaders reward a single defection with either valuable committee assignments, beneficial violations of seniority norms, or both. A wealth of anecdotal evidence shows that leaders and elites more broadly (including the executive branch, staffers, and news media) demonstrate strong concern for party affiliation and the behaviors and values they associate with it. The committee assignment behavior presented here shows in concrete terms that modern leaders are willing to bargain with prospective party switchers. Further evidence shows that, beyond granting special 
consideration in the committee assignment process, certain elites take grave personal offense at party switching and seek with no small amount of relish to either support a newcomer or condemn a departed colleague. Some portion of this attitude and behavior may be based in political gamesmanship, but, at least while the "game" is in progress, elites clearly order its rules with regard to two partisan teams.

The preponderance of research on the subject of group identity suggests that the differential pressure legislators experience as their social environments shift may in part be the result of deep-seeded social-psychological predispositions. Time and again social psychology research has shown that even under the flimsiest of pretenses, the idea that one belongs to a group colors social evaluations (e.g., Brewer 1979; Lemyre and Smith 1985; Tajfel 1970). To expect legislators to be immune to these basic socialpsychological responses would ignore their natural human reactions to social pressures and responses. A much more reasonable expectation is that switchers will adapt to their new environments, making the necessary changes to find as much success as possible with their new backers, colleagues, and constituents. Legislators are, after all, acutely aware that their behavior is under scrutiny and have little reason to leave their messages unchanged when their political and professional circumstances shift so dramatically.

In the case studies examined here, I show that party switchers have relatively large swings in the geographic distribution of their electoral support. These shifts in support are predicted by both the partisan character of the region and by its racial composition, two variables that are themselves highly correlated. In the modern electoral environment, officials and candidates are acutely aware that racial lines tend to be distinctly partisan lines. Only in the rare case that a district has a distinctly low number 
of African-American voters is one likely to see a result like the one Nathan Deal experienced, which was characterized by relatively low shifts in geographic support. Even in Deal's case, that change in electoral backing was distinctly and significantly partisan. In all the other more racially and ideologically diverse voting regions, the correlation of changing vote shares with partisan support and racial makeup was nearly absolute and occurred in the predicted directions.

In short, the large majority of voting behavior can be predicted by party affiliation (assuming "leaners" are included in the evaluation). Why, then, would one expect changes in a legislator's party affiliation to do anything other than push away voters identifying with his former party and bring in those who identify with the new one? Party affiliation may not override all other mitigating factors in each legislator's case, but it is clearly a strong source of change in electoral support. Arlen Specter believed the only way to remain in office was to use the power of party in the electorate to his advantage, and he said as much publicly. Although his political fortunes fell short of his hopes, his expectation of mass changes in electoral support have been echoed by numerous other politicians, solidified by shifting endorsements from politicians and sometimes from journalists, and borne out by the evidence I present here.

The importance of this study lies in the effort to deepen scholarly understanding of the effects of partisanship. For the study of political parties to progress, it is important that researchers continue to combine measurable, often quantitative analysis with realworld context. It is not enough to assert that party influences legislative behavior independent of a legislator's innate ideological predispositions. This analysis has gone 
further to elucidate precisely how the legislative environment changes as party affiliation is altered, even holding the legislator himself constant.

\section{Inconsistent Success of Party Switchers}

Taken together, the effects I demonstrate in this analysis amount to substantial environmental shifts for any party switcher, and although they are profound, these factors are not wholly unmitigated by other factors. One likely predictor of electoral success following a party switch is the character of the major parties in one's electoral district. It is not an accident that so many southern conservative Democrats decided to become Republicans around the time of the Republican takeover of Congress in 1995. The new majority had benefits to offer, and southern Democrats (both voters and those serving in office) were similar enough to Republicans in ideology that switchers could feel optimistic that voters would understand the decision. Further, those switchers could claim that their decision benefitted constituents as Republicans generally offered better committee assignments than switchers had had under the Democratic majority. In many ways, the tide of party switchers seemed to punctuate the larger trend of partisan realignment that characterized the electorate in southern states.

Another factor that seems to affect successful party switching is adeptness of campaign communication. Most party switchers make a standard argument about the extreme views of the party they are leaving and cast themselves as independents whether or not they expressly join the opposing party. Arlen Specter’s statement about switching to the Democratic Party included such claims, but he also made a rare admission of an electoral rationale. In the statement, he said, "I am not prepared to have my 29-year record in the United States Senate decided by the Republican primary electorate” (Hulse 
and Nagourney 2009). This short sentence implies both that he switched in order to retain office (something most legislators desire, but few admit openly) and that he was unhappy not just with Republican legislators or leadership, but with the voters themselves. It is unclear whether this statement was an attempt to curry favor with his new Democratic base or simply to give a candid explanation of his thinking. The political gaffe the statement represented was less ambiguous. Voters may gravitate to a candidate that they see as above the political fray, but one who more or less admits to choosing a party based on electoral considerations has a much more difficult case to make.

Conservative Democratic Sen. Strom Thurmond, by contrast, had credibility among South Carolina voters as an independent, having won three southern states in his 1948 for president as a Dixiecrat. He continually touted his claim that he was an independent, upset with the Democratic Party’s policy positions, especially those concerning civil rights and states rights. When Thurmond became a Republican 4 years into a 6-year term, he declared “I've always been independent, regardless of what party I've been in," going on to suggest that he would break with Republicans as well if he disagreed with them (Sittons 1964).

His decision came just over 2 months after the Civil Rights Act of 1964 was signed into law, and there can be little doubt that many of Thurmond's constituents saw his defection as a principled stand against the movement to force southern states to grant African Americans full civil rights. However unpalatable that position may seem today, one thing was clear: Thurmond knew his audience. His adept handling of his message and the timing of his party switch led to a huge win in the 1966 election. In that contest 
he trounced his challenger, Democratic State Sen. Bradley Morrah, winning more than 60 percent of the vote (Clerk of the House of Representatives 1967). Thurmond went on to continued electoral success. To date, he is the third longest-serving senator in U.S. history.

The ability to communicate effectively and credibly with the public is a difficult concept to quantify, but, to paraphrase Supreme Court Justice Potter Stewart’s comment about pornography, people generally know it when they see it. Future research could shed considerable light on the subject of credibility in political communication by examining the appeals that party switchers make to the public when they decide to take the risk of leaving one party for another. Although I do not present a systematic quantitative analysis of such appeals here, there is considerable anecdotal evidence that manner in which a party switcher "sells" his decision has some impact on the electoral success (or lack thereof) that follows.

The limited cases examined here for evidence of shifts in geographic constituency tell relatively consistent stories, and those stories are supported by the interviews I conducted. It should be no surprise to scholars of American elections that some large segments of the electorate are partisan. Although much of the South has transitioned from supporting conservative Democrats to conservative Republicans, African-American voters have generally not followed that path. The results that are consistent across all the cases I examine are that strongly partisan regions are reluctant to support legislators who abandon their party of choice and that regions with large African-American populations behave similarly. Neither result is shocking, but both reinforce the claim that party status is tied to the geographic distribution of electoral support. Since these cases contrast the 
behavior of voters over a relatively short time period, it is unlikely that these results are driven by mass voter migration. The explanation that African Americans and other partisan Democrats prefer Democratic candidates, and partisan Republicans prefer Republican candidates, is considerably more likely. It is telling that the one case I analyze that does not conform as neatly to the idea that changing party status prompts major shifts in electoral support is that of Nathan Deal, a legislator representing a district with an African-American population of just over 3 percent.

\section{Future Research}

There are many avenues one could fruitfully pursue in the study of party switchers. One is the effect of switching on political communication. The degree to which MCs change their rhetoric and even their methods of communication after defecting could reveal new information about the way politicians approach partisan audiences. This question could be answered by using any number of methods for rhetorical analysis, either quantitative or qualitative. One could, for example, apply Groseclose's slant quotient, a measure of politically charge language, to rhetoric produced before and after switching parties.

Such an analysis could follow one of several paths. For example, a rhetorical analysis of party switchers could focus on the switching event itself, perhaps considering the relative level of vitriol directed at the former party in public statements. That data could be used as a dependent variable in a study designed to elucidate the predictors of party alienation. It is clear that some switchers have experiences that are intensely negative, but I am unaware of any research that addresses the causes of extreme alienation within legislative parties. 
Rhetorical analysis could also be employed to examine the ways in which switchers address their constituents once political tensions subside following the defection. This study establishes that various constituencies shift and environmental factors adjust with changes in party affiliation. As a next step, one might analyze what changes those shifts in environment produce on issue focus or message tone. A straightforward research question, for example, might concern whether switchers to the Democratic Party are more inclined than before to discuss issues "owned” by Democrats under the framework of issue ownership established in political science scholarship (e.g., Petrocik 1996). Alternatively, one could use those issue categories to judge the tone of arguments about a party-owned issue before and after a party switch. Does a speech about crime policy sound different when it is delivered by a member connected with one party than it does when he is affiliated with the other?

Another useful endeavor would be to track a party switcher's campaigning and fundraising activities using qualitative materials such as personal notes, letters, and agendas. This kind of effort could yield candid (if anecdotal) results, showing how a candidate may have changed strategy to appeal to a new party's voters and donors. This kind of qualitative analysis is difficult to do well, but it might elucidate some of the finer points candidates must consider when approaching a new partisan environment. One limitation of qualitative analysis based in interviews and media accounts is the potential for personal bias to influence the tone and content of information provided to the researcher. Personal documents would be far less likely to contain the sort of spin that a politician might otherwise try to impart to reporters or scholarly interviewers.

\section{Closing Thoughts}


In speaking with the party switchers whose stories I attempt to unravel here, I was struck by the humanity and the conviction they communicated. That is not to deny the careful strategies they often applied to their political circumstances. Far from the public perception of agents operating in a corrupt and cynical system, these are men who seemed genuinely committed to their goals. However, the reactions to their defections by colleagues, leaders, and staffers were colored by equally passionate and strongly partisan views. Moreover, a sense of gamesmanship was prevalent throughout my qualitative research, and a game requires opposing teams. For legislators, like voters, parties are not just labels; they are evidence, not always correctly interpreted, of commonality and difference. In no portion of my studies, even in examining switchers to independent status, did I come across a case in which a party switch produced no major fallout. The MCs' political identities were transformed for better or worse by little more than a flip of a switch from "D" to "R" or vice versa. In the interviews I conducted and in public statements, nearly all party switchers claimed ideological conviction unfettered by partisan bonds. Perhaps the most striking evidence of party's importance is just how few people were willing to listen. 


\section{Bibliography}

American Conservative Union. 2011. Ratings of Congress. http:/www.conservative.org/ congress-ratings/ (May 15, 2011).

Americans for Democractic Action. 2011. Voting Records. http://www.adaction.org/ pages/publications/voting-records.php (May 15, 2011).

Aldrich, John H. 1995. Why parties? The Origin and Transformation of Political Parties in America. Chicago: University of Chicago Press.

Aldrich, John H., and William T. Bianco. 1992. "A Game-Theoretic Model of Party Affiliation of Candidates and Office Holders.” Journal of Mathematical and Computer Modeling 16: 103-16.

Aldrich, John H., and David W. Rohde. 1998. "The Transition to Republican Rule in the House: Implications for Theories of Congressional Politics.” Political Science Quarterly 112: 541-67.

. 2000. "The Republican Revolution and the House Appropriations Committee.” Journal of Politics 62: 1-33.

Alpert, Bruce. March 6, 2004. “La. Congressman to Stay with Demos; Alexander Persuaded by Party Loyalists,” Times-Picayune.

January 7, 2005. “Appointments Help in Restoring Clout to La. Delegation; McCrery, Alexander Land Coveted Posts,” Times-Picayune.

Alvarez, Lizette. August 7, 2000. “G.O.P. Aims For Revenge On Defector In Congress,” New York Times.

American National Election Studies. 2010. The ANES Guide to Public Opinion and Electoral Behavior. http://electionstudies.org/nesguide/toptable/tab2a_2.htm (May 16, 2011).

Angwin, Julia. March 11, 1995. “Most Donors Accept Switch,” Denver Post. June 20, 1995. “Campbell’s Ex-staffers Sad, Bitter,” Denver Post.

Ansolabehere, Stephen, Rebecca Lessem, and James M. Snyder Jr. 2006. “The Orientation of Newspaper Endorsements in U.S. Elections, 1940-2002.” Quarterly Journal of Political Science 1: 393-404.

Arnold, R. Douglas. 1990. The Logic of Congressional Action. New Haven, CT: Yale University Press. 
Austen-Smith, David. 1995. “Campaign Contributions and Access.” American Political Science Review 89: 566-81.

Babcock, Charles R., and Brian Faler. September 8, 2006. "Shelby Steers \$50 Million to Projects, Aiding Donor.” Bloomberg. http://www.bloomberg.com/apps/news? pid=newsarchive\&refer=home\&sid=ab27Rz5OHUZU (January 4, 2012).

Baker, Ross K. 1985. "Party and Institutional Sanctions in the U.S. House: The Case of Congressman Gramm.” Legislative Studies Quarterly 10: 315-337.

Balz, Dan. May 17, 1990. “Gov. Casey Faces Weakened Opponent; In Pennsylvania, Toll From Abortion Issue Is Two Incumbents.” Washington Post.

Barry, Dan. November 1, 1996. “In L.I. Contest, Incumbent Charges 'Catholic Bashing' by Challenger,” New York Times.

Bartels, Larry M. 1991. "Constituency Opinion and Congressional Policy-Making: The Reagan Defense Buildup.” American Political Science Review 85: 457-74.

Benoit, William L., and David Airne. 2005. “Issue Ownership for Non-Presidential Television Spots.” Communication Quarterly 53: 493-503.

Berke, Richard L. May 3, 1994. “G.O.P. Seeking Convert in Alabama Democrat.” New York Times.

Binder, Sarah A., Eric D. Lawrence, and Forrest Maltzman. 1999. "Uncovering the Hidden Effect of Party.” Journal of Politics 61: 815-831.

Box-Steffensmeier, Janet M., Laura W. Arnold, and Christopher J. W. Zorn. 1997. "The Strategic Timing of Position Taking in Congress: A Study of the North American FreeTrade Agreement” American Political Science Review 91: 324-38.

Brewer, Marilynn B. 1979. "In-group Bias in the Minimal Intergroup Situation: A Cognitive Motivational Analysis.” Psychological Bulletin 86: 307-24.

Brewer, Marilynn B., and Rupert J. Brown. 1998. “Intergroup Relations.” In The Handbook of Social Psychology, eds. Daniel T. Gilbert, Susan T. Fiske, and Gardner Lindzey. New York: McGraw-Hill 554-94.

Broder, David S. August 12, 2004. “Turncoat Politics.” Washington Post.

Brown, Thad A. 1988. Migration and Politics: The impact of Population Mobility on American Voting Behavior. Chapel Hill: University of North Carolina Press.

Burmila, Edward M. N.d. "Party Switching among Incumbent State Legislators.” Manuscript, Indiana University - Bloomington. 
Byrd, Harry F. Jr. 1998. Defying the Odds: An Independent Senator's Historic Campaign. Charlottesville, VA: Howell.

Campbell, Angus, Philip E. Converse, Warren E. Miller, and Donald E. Stokes. 1960. The American Voter. New York: Wiley.

Campbell, James E. 1982. “Cosponsoring Legislation in the US Congress.” Legislative Studies Quarterly 7: 415-22.

Carlin, John. March 4, 1995. "Defecting Indian Senator Comes to the Aid of Dole.” The Independent (London).

Choate, Judd. 2003. Torn and Frayed: Congressional Norms and Party Switching in an Era of Reform. Westport, CT: Praeger.

Christensen, Mike. February 15, 1995. "Conservative Deal Weighing Shift to GOP; Georgia Democrat Often Votes with Republicans,” Atlanta Journal Constitution.

April 11, 1995. "No Perks for Switch, Deal Says; ‘A Very Personal Thing’: Congressman Says there was No Talk of Political Horse Trading with Republicans,” Atlanta Journal Constitution.

Clerk of the House of Representatives. 1967. Statistics of the Congressional Election of November 8, 1966. Washington, D.C.: U.S. Government Printing Office.

1983. Statistics of the Congressional Election of November 2, 1982. Washington, D.C.: U.S. Government Printing Office.

. 2011a. Black Americans in Congress. http://baic.house. gov/member-profiles/ (July 7, 2011).

2011b. Women in Congress. http://womenincongress.house. gov/member-profiles/ (July 7, 2011).

Clines, Francis X. July 13, 1995. “G.O.P. Courts Another Eager Convert.” New York Times.

Cox, Gary, and Matthew McCubbins. 1993. Legislative Leviathan. Berkeley, CA: University of California Press.

2005. Setting the Agenda: Responsible Party Government in the US House of Representatives. New York: Cambridge University Press.

C-SPAN. 2009. "Senator Specter Announcement on Party Switch.” http://www.cspanvideo.org/program/285563-1 (February 8, 2012). 

. 2010. "Senator Specter Farewell Address and Tribute." http://www.c-spanvideo.org/program/297191-5 (February 14, 2012).

Dao, James. July 18, 1999. “Long Island Congressman Quits G.O.P., Citing 'Extremists.”' New York Times.

Davidson, Roger H., Walter J. Oleszek, and Frances E. Lee. 2010. Congress and Its Members. $12^{\text {th }}$ ed. Washington, D.C.: CQ Press.

Desposato, Scott W. 2006. "Parties for Rent? Careerism, Ideology, and Party Switching in Brazil's Chamber of Deputies." American Journal of Political Science 50: 6280.

Erikson, Robert S., John P. McIver, and Gerald C. Wright Jr. 1987. "State Political Culture and Public Opinion.” American Political Science Review 81: 797-814.

Eulau, Heinz, and Paul D. Karps. 1977. "The Puzzle of Representation: Specifying Components of Responsiveness.” Legislative Studies Quarterly 2: 233-54.

Evans, Diana. 1996. "Before the Roll Call: Interest Group Lobbying and Public Policy Outcomes in House Committees.” Political Research Quarterly 49: 287-304.

Evans, Rowland, and Robert Novak. April 8, 1981. "The Revenge of the Boll Weevils," The Washington Post.

Federal Election Commission. 2011. "2010 House and Senate Campaign Finance.” http://fec.gov/disclosurehs/hsnational.do (February 21, 2012).

Feldmann, Linda. May 28, 2010. “Joe Sestak Job Offer? White House Says It Did Nothing Wrong.” Christian Science Monitor.

Fenno, Richard F. 1977. "U.S. House Members in their Constituencies: An Exploration.” American Political Science Review 71: 883-917. 1978. Home Style: House Members in Their Districts. Boston: Little, Brown.

Fiorina, Morris P. 1974. Representatives, Roll Calls, and Constituencies. Lexington, MA: Lexington Books.

Fitzgerald, Thomas. August 28, 2009. "FEC Says Group Can Prod Donors on Specter Refund.” Philadelphia Inquirer.

. September 16, 2009. "Obama Gives Specter a Boost at Fundraiser.” Philadelphia Inquirer. 
Fowler, James H. 2006. "Legislative Cosponsorship Networks in the US House and Senate.” Social Networks 28: 454-65.

Freeman, Jo. 1986. “The Political Culture of the Democratic and Republican Parties.” Political Science Quarterly 101: 327-56.

Gay, Claudine. 2002. "Spirals of Trust? The Effect of Descriptive Representation on the Relationship Between Citizens and their Government.” American Journal of Political Science 46: 717-32.

Georgia Secretary of State. 2010. Georgia Election Results. http://sos.georgia.gov/ elections/election_results/2010_1102/swfed.htm (June 26, 2011).

Grenzke, Janet M. 1989. "PACs and the Congressional Supermarket: The Currency is Complex.” American Journal of Political Science 33: 1-24.

Grose, Christian R. and Antoine Yoshinaka. 2003. “The Electoral Consequences of Party Switching by Incumbent Members of Congress, 1947-2000.” Legislative Studies Quarterly 28: 55-75.

Groseclose, Tim and Charles Stewart, III. 1998. "The Value of Committee Seats in the House, 1947-91.” American Journal of Political Science 42: 453-74.

Grunwald, Michael. February 18, 1999. "Labor Targets Ally Who Crossed Line; Vote to Impeach May Cost Buffalo Republican Quinn.” Washington Post.

Hall, Richard L., and Frank W. Wayman. 1990. "Buying Time: Moneyed Interests and the Mobilization of Bias in Congressional Committees.” American Political Science Review 84: 797-820.

Hart, Ariel. September 2, 2004. "National Briefing South: Louisiana: Challenger Wants Congressman Off Ballot.” New York Times.

Heller, William B. and Carole Mershon. 2005. "Party Switching in the Italian Chamber of Deputies, 1996-2001” Journal of Politics 67: 536-59.

Hibbing, John R. and David Marsh. 1987. "Accounting for the Voting Patterns of British MPs on Free Votes.” Legislative Studies Quarterly. 12: 275-97.

Hoberock, Barbara. November 6, 1996. “3rd District Voters Again Pick Watkins,” Tulsa World.

Huckfeldt, Robert, Paul E. Johnson, and John Sprague. 2002. "Political Environments, Political Dynamics, and the Survival of Disagreement.” Journal of Politics 64: 121. 
Diverse Opinions Within Communication Networks. New York: Cambridge University Press.

Hulse, Carl. December 22, 2010. “Farewells; Sharp Words from Specter.” New York Times.

Hulse, Carl, and Adam Nagourney. April 29, 2009. "Specter Switches Parties; More Heft for Democrats." New York Times.

Hurt, Charles. August 10, 2004. “Democrats Howl at Party Hopping.” Washington Times.

Jackson, David J., and Steven T. Engel. 2003. “Don’t Bite the PAC That Feeds You Business PAC Punishment Over the China Vote.” American Politics Research 31: 138-154.

Jacobs, Jeremy. April 28, 2009. “Cornyn: Specter’s Switch is 'Political SelfPreservation.” The Hill.

Jenkins, Jeffery A. 1999. "Examining the Bonding Effects of Party: A Comparative Analysis of Roll-Call Voting in the U.S. and Confederate Houses.” American Journal of Political Science 43: 1144-65.

Johnson, Bertram and Robert van Houweling. 1999. "The Best Money Congress Can Buy: Legislative Fundraising and the Donor Collective Action Problem.” Paper presented at the annual meeting of the Midwest Political Science Association.

Kahn, Kim Fridkin, and Patrick J. Kenney. 2002. "The Slant of the News: How Editorial Endorsements Influence Campaign Coverage and Citizens' Views of Candidates.” American Political Science Review 96: 381-394.

Kelley, Tina. September 20, 2000. "New Tally Confirms an Upset in Primary,” New York Times.

. November 8, 2000. "The 2000 Elections: The House; Democrat Captures Lazio’s Long Island Seat,” New York Times.

Kellman, Laurie. April 11, 1995. "Democrat's defection gives GOP new Deal.” Washington Times.

Kessler, Daniel, and Keith Krehbiel. 1996. "Dynamics of cosponsorship.” American Political Science Review 90: 555-66.

Key, V. O. Jr. 1964. Politics, Parties, and Pressure Groups. 5th ed. New York: Crowell. 
Koger, Gregory. 2003. "Position Taking and Cosponsorship in the US House.” Legislative Studies Quarterly 28: 225-46.

Krehbiel, Keith. 1991. Information and Legislative Organization. Ann Arbor, MI: University of Michigan Press.

23: 235-266.

1993. “Where’s the Party?” British Journal of Political Science . 1995. "Cosponsors and Wafflers from A to Z.” American Journal of Political Science 39: 906-23.

Krienen, Fenna M., Pei-Chi Tu, and Randy L. Buckner. 2010. “Clan Mentality: Evidence That the Medial Prefrontal Cortex Responds to Close Others.” The Journal of Neuroscience 30: 13,906-15.

Kweit, Mary Grisez. 1986. "Ideological Congruence of Party Switchers and Nonswitchers: The Case of Party Activists." American Journal of Political Science 30:184-96.

Lamont, Michèle, and Virág Molnár. 2002. "The Study of Boundaries in Social Sciences.” Annual Review of Sociology 28: 167-95.

Leibovich, Mark. May 2, 2009. “He Flipped!” New York Times.

Lemyre, Louise, and Philip M. Smith. 1985. "Intergroup Discrimination and Self-Esteem in the Minimal Group Paradigm.” Journal of Personality and Social Psychology 49: 660-70.

Levy, Mark. May 13, 2010. "Party-switcher Specter, Challenger Sestak Fight Over Who’s True Democrat in Pa. Senate Race.” Star Tribune.

Lewis-Beck, Michael S., William G. Jacoby, Helmut Norpoth, and Herbert F. Weisberg. 2008. The American Voter Revisited. Ann Arbor, MI: University of Michigan Press.

Lynn, Frank. 1975. “Rockefeller Aide Assails Peyser,” New York Times, 14 March.

MacDonald, Jason A., and William W. Franko Jr. 2008. "What Moves Partisanship? Migration, State Partisan Environmental Change, and Party Identification.” American Politics Research 36: 880-902.

Maginnis, John. August 11, 2004. "Demos Can Only Rail Helplessly at Switch,” TimesPicayune. 
Margolis, John. March 17, 1997. “A U.S. Senator Who Shoots from the Hip.” High Country News.

Marsh, David and Melvyn Read. 1988. Private Members' Bills. Cambridge: Cambridge University Press.

Martis, Kenneth C. 1989. The Historical Atlas of Political Parties in the United States Congress, 1789-1989. New York: Macmillan.

Mayhew, David R. 1974. Congress: The Electoral Connection. New Haven, CT: Yale University Press.

McCarty, Nolan, Keith T. Poole, and Howard Rosenthal. 2001. "The Hunt for Party Discipline in Congress.” American Political Science Review 95: 673-687.

McQuiston, John T. July 25, 1999. “Same Congressman, New Party,” New York Times.

Miller, Donald, and Donald E. Stokes. 1963. "Constituency Influence in Congress.” American Political Science Review 57: 45-56.

Miller, Judith. February 22, 1981. "House Democrats Grumble That Leaders Are Drifting,” New York Times.

Miniclier, Kit. September 3, 1995. "Ben: I'm Not Done Yet, But Campbell Coy about his Future,” Denver Post.

Mitchell, Alison. May 27, 1999. "6 Republicans Break Ranks on Campaign Finance Issue.” New York Times.

Nelson, Garrison. N.d. “Committees in the U.S. Congress, 1947-1992,” Congressional Committees, Historical Standing Committees, Charles Stewart's Congressional Data Page, Accessed: 3 April 2013. <http://web.mit.edu/17.251/www/data_ page.html\#0>.

Nieves, Evelyn. August 13, 2004. “The One Invitation That Counts.” Washington Post.

Nokken, Timothy P. 2000. "Dynamics of Congressional Loyalty: Party Defection and Roll-Call Behavior, 1947-97.” Legislative Studies Quarterly 25: 417-444. . 2005. "Party Switching and the Procedural Party Agenda in the U. S. House of Representatives, 1953-2002.” Paper presented at the Legislative Party Switching Conference, Charlottesville, VA, July.

Nokken, Timothy P., and Keith T. Poole. 2004. "Congressional Party Defection in American History.” Legislative Studies Quarterly 29: 545-568. 
Nunnally, Derrick. April 30, 2009. “Specters Says He’d Return Donations.” Philadelphia Inquirer.

O’Brien, Michael. March 8, 2010. "Specter: Use Majority-vote Rule on Healthcare to 'fight fire with fire."” The Hill.

OpenSecrets.org. 2008. 2008 Overview. November 21, 2008. Center for Responsive Politics. Accessed: 21 November 2008

$<$ http://www.opensecrets.org/overview/index.php>.

. 2010. Revolving Door: Former Members. September 23, 2010.

Center for Responsive Politics. Accessed: 23 September 2010

$<$ http://www.opensecrets.org/revolving/top.php?display=Z $>$.

Oppenheimer, Bruce I. and Andrea C. Hatcher. 2003. "Congressional Party Switchers, 1876-2002: The Effect of Party and Constituency on Strategic Behavior.” Manuscript, Vanderbilt University.

Ornstein, Norman J., Thomas E. Mann, and Michael J. Malbin. 2009. Vital statistics on Congress 2008. Washington, D.C.: Brookings Institution Press.

1998. Vital statistics on Congress 1997-1998. Washington, D.C.: American Enterprise Institute Press.

Overby, L. Marvin. 1996. "Free Voting in a Provincial Parliament: The Case of 'SameSex’ Legislation in Ontario, 1994.” Journal of Legislative Studies 2: 172-83.

Overby, L. Marvin, Ray Tatalovich, and Donley T. Studlar. 1998. "Party and Free Votes in Canada: Abortion in the House of Commons." Party Politics 4: 381-92.

Patterson, Samuel C. 1968. “The Political Culture of the American States.” Journal of Politics 30: 187-209.

Peters, Ronald M. Jr. 1999. "Institutional Context and Leadership Style: The Case of Newt Gingrich.” In New Majority or Old Minority?: The Impact of Republicans on Congress, ed. Nicol C. Rae and Colton C. Campbell. Lanham, MD: Rowman \& Littlefield.

Petrocik, John R. 1996. "Issue Ownership in Presidential Elections, with a 1980 Case Study.” American Journal of Political Science 40: 825-850.

Petrocik, John R., William L. Benoit, and Glenn J. Hansen. 2003-2004. "Issue Ownership and Presidential Campaigning, 1952-2000.” Political Science Quarterly 118: 599-626.

Poole, Keith T. 2007. “Changing Minds? Not in Congress!” Public Choice 131:435-451. 
Poole, Keith T., and Thomas Romer. 1985. "Patterns of Political Action Committee Contributions to the 1980 Campaigns for the United States House of Representatives.” Public Choice 47: 63-111.

Raju, Manu, and John Bresnahan. July 29, 2010. "Sen. Shelby Steers Cash to Ex-aides.” Politico. http://www.politico.com/news/stories/0710/40388.html (January 4, 2012).

Renka, Russell D., and Daniel E. Ponder. 2007. "Violations of Committee Seniority in the U.S. House.” Paper presented at the annual meeting of the Midwest Political Science Association, Chicago, IL. http://citation.allacademic.com//meta/p_mla_ apa_research_citation/1/9/6/9/7/pages196978/p196978-1.php (June 16, 2013).

Rickards, Dylan Scott. 2004. "Predicting Party Switching in U.S. State Legislatures." Manuscript, Louisiana State University.

Rockwell, Llewellyn Jr. April 8,1993. “Rebel Senator with a Cause,” Washington Times.

Rohde, David W. 1991. Parties and Leaders in the Postreform House. Chicago: University of Chicago Press.

Romano, Lois. January 10, 1983. "Phil Gramm’s Switch \& Fight,” The Washington Post.

Rosenthal, Howard, and Keith Poole. 2011. Rank Ordering for All Houses and Senates. http://voteview.com/senrank.asp (May 3, 2011).

Rudolph, Thomas J. 1999. "Corporate and Labor PAC Contributions in House Elections: Measuring the Effect of Majority Party Status.” Journal of Politics 61: 195-206.

Schiller, Wendy J. 1995. "Senators and Political Entrepreneurs: Using Bill Sponsorship to Shape Legislative Agendas.” American Journal of Political Science 39: 186203.

Schmitt, Eric. July 20, 1999. "House's Newest Democrat Finds Himself Without a Staff," New York Times.

Schneider, Judy. 2010. House Committees: Categories and Rules for Committee Assignments. Washington: Congressional Research Service. 2012. Senate Committees: Categories and Rules for Committee Assignments. Washington: Congressional Research Service.

Seelye, Katharine Q. March 4, 1995. "Democrats Lose Senate Seat with Switch by Coloradan,” New York Times. 
Sherman, Jerome L. April 22, 2006. "Specter Offers Support, Advice to Swann.” Pittsburgh Post-Gazette.

Sittons, Claude. September 17, 1964. "Thurmond Break is Made Official; He Will Work as Republican for Goldwater Election.” New York Times.

Smirnov, Oleg. Christopher T. Dawes, James H. Fowler, Tim Johnson, and Richard McElrath. 2010. "The Behavioral Logic of Collective Action: Partisans Cooperate and Punish More Than Nonpartisans." Political Psychology 31: 595616.

Smith, Richard A. 1995. "Interest Group Influence in the U.S. Congress.” Legislative Studies Quarterly 20: 89-139.

Snyder, James M. Jr. 1992. “Artificial Extremism in Interest Group Ratings.” Legislative Studies Quarterly 17: 319-45.

Specter, Arlen. 2009. "Statement from Senator Arlen Specter.” Time Politics. Accessed: 8 February, 2012. <http://www.time.com/time/politics/article/0,8599,1894384, 00.html> 2012. Life Among the Cannibals: A Political Career, a Tea Party Uprising, and the End of Governing As We Know It. New York: Thomas Dunne Books.

State News Service. March 26, 1993. "Shelby Not Shying Away from White House Attacks; Denies He Would Switch Parties."

Stewart, Charles M., III and Jonathan Woon. 2011. "Congressional Committee Assignments, 103rd to 112th Congresses, 1993-2011," Congressional Committees, Modern Standing Committees, Charles Stewart's Congressional Data Page, Accessed: 3 April 2013. <http://web.mit.edu/17.251/www/data_ page.html\#2>.

Tajfel, Henri. 1970. "Experiments in Intergroup Discrimination.” Scientific American 23: 96-102.

Tajfel, Henri, and Michael Billic. 1974. "Familiarity and Categorization in Intergroup Behavior.” Journal of Experimental Social Psychology 10: 159-70.

Tam Cho, Wendy K. and James H. Fowler. 2010. "Legislative Success in a Small World: Social Network Analysis and the Dynamics of Congressional Legislation." Journal of Politics 72: 124-35.

The Real Arlen Specter. 2010. "The Switch.” 6 May. http://www.youtube.com/watch?v=x97DdZho11k (February 8, 2012). 
Tolchin, Martin. March 7, 1975. “Peyser Will Run for Buckley Seat,” New York Times.

U.S. Census Bureau. 2000. “Census 2000 Redistricting Data (Public Law 94-171) Summary File.” Accessed: 12 May 2012 < http:/factfinder2.census.gov/faces/ tableservices/jsf/pages/productview.xhtml?pid=DEC_00_PL_QTPL\&prodType=t able>.

. 2008. “State \& County QuickFacts.” Accessed: 30 December $2008<\mathrm{http}$ //quickfacts.census.gov/qfd/maps/>.

Virginia Department of Mines, Minerals and Energy - Division of Geology and Mineral Resources. 2006. Coal. http://www.dmme.virginia.gov/DMR3/coal.shtml (May 16, 2011).

Wilhite, Allen and John Theilmann. 1987. "Labor PAC Contributions and Labor Legislation: A Simultaneous Logit Approach.” Public Choice 53: 267-276.

Wilson, Rick K. and Cheryl D. Young. 1997. "Cosponsorship in the United States Congress.” Legislative Studies Quarterly 22: 24-43.

Wilson, Woodrow. 1885. Congressional Government: A Study in American Politics. Boston: Houghton Mifflin.

Wright, Gerald C. Jr. 1989. "Policy Voting in the U.S. Senate: Who Is Represented?” Legislative Studies Quarterly 14: 465-86.

Wright, John R. 1990. “Contributions, Lobbying, and Committee Voting in the U.S. House of Representatives.” American Political Science Review 84: 417-38.

Yoshinaka, Antoine. 2005. "Congressional Party Switchers and Committee Assignments: Who Gets 'What, When, How.”’ Legislative Studies Quarterly 30: 391-406. 
VITA

Benjamin Lacy Hall was born to David and Joyce Hall in Carol Steam, Illinois, a suburb of Chicago. He grew up in Chattanooga, Tennessee with his sister Anna and brothers Ian and Nathan. He attended the McCallie School in Chattanooga, and went on to earn a Bachelor of Arts degree in English from Beloit College. There he served as a writer and the editor-in-chief for the school's weekly newspaper, the Round Table. Prior to attending graduate school at the University of Missouri, Ben served as a cab driver in Madison, Wisconsin. He completed his dissertation while working as a digital content developer for Cengage Learning in Boston. 